University of Arkansas, Fayetteville

ScholarWorks@UARK

Graduate Theses and Dissertations

7-2015

\title{
Effects of Intervention on Self-Regulated Learning for Second Language Learners
}

$\mathrm{Lu} \mathrm{Yu}$

University of Arkansas, Fayetteville

Follow this and additional works at: https://scholarworks.uark.edu/etd

Part of the Bilingual, Multilingual, and Multicultural Education Commons, Curriculum and Instruction Commons, and the Educational Psychology Commons

Citation

Yu, L. (2015). Effects of Intervention on Self-Regulated Learning for Second Language Learners. Graduate Theses and Dissertations Retrieved from https://scholarworks.uark.edu/etd/1229

This Dissertation is brought to you for free and open access by ScholarWorks@UARK. It has been accepted for inclusion in Graduate Theses and Dissertations by an authorized administrator of ScholarWorks@UARK. For more information, please contact scholar@uark.edu. 
Effects of Intervention on Self-Regulated Learning for Second Language Learners 
Effects of Intervention on Self-Regulated Learning for Second Language Learners

A dissertation submitted in partial fulfillment

of the requirements for the degree of

Doctor of Philosophy in Curriculum and Instruction

by

$\mathrm{Lu} \mathrm{Yu}$

Tianjin Foreign Studies University

Bachelor of Arts in English, 1995

Tianjin Normal University

Master of Arts in English Education, 2002

July 2015

University of Arkansas

This dissertation is approved for recommendation to the Graduate Council.

Dr. Felicia Lincoln

Dissertation Director

Dr. Michael K. Daugherty

Dr. Michael J. Wavering

Dissertation Committee

Dissertation Committee

Dr. Wen-Juo Lo

Dissertation Committee 


\begin{abstract}
The purposes of the study were to investigate the process of self-regulated learning and the effects of an intervention program on self-regulated learning designed for second language (L2) learners. 120 participants who were sophomores majoring in English education at a university in an Asian country were randomly assigned to either the experimental group or control group. The self-regulated learning intervention was composed of six weekly two-hour training sessions that focus on five main variables of self-regulatory process: goal setting, selfefficacy, time and study environment management, language learning strategies, and attribution. The operation of self-regulated learning processes in the context of L2 learning, and the effectiveness of the self-regulated learning intervention program for L2 learners were investigated and analyzed.

Results of a path analysis reflected Zimmerman's process model of self-regulation (2000, 2004) and suggested that there are causal influences of self-regulated learning variables across three phases (forethought, performance, and reflection phase) in the context of L2 learning. Furthermore, student self-regulation influences their L2 proficiency via the enhancement of motivational variables. Self-efficacy, time and study environment management skills, and students' learning time affected their L2 proficiencies directly. Intrinsic goal orientation influenced L2 proficiency indirectly through its impact on time and study environment management skills. Attribution affected L2 proficiency indirectly through its impact on learning time. The evaluation of the effectiveness of the intervention included multiple outcome variables, which were grouped into three categories: students' motivational beliefs, students' strategy use, and students' academic performance. The results of the immediate training effects on goal setting, self-efficacy, attribution, time and study environment management, memory strategy,
\end{abstract}


compensation strategy, metacognitive strategy and L2 proficiency confirmed that academic selfregulation is a trainable student characteristic and self-regulation training can be used effectively in a L2 classroom setting. The feature of the current study design allows for systematically examining and evaluating both motivational variables and learning strategies in the context of L2 learning. From a pedagogic point of view, this finding has implications for the design of strategy-based instruction intended to foster students' self-regulated learning in the L2 classroom. 
C 2015 by $\mathrm{Lu} \mathrm{Yu}$

All Rights Reserved 


\section{ACKNOWLEDGEMENTS}

Over the past four years I have received support and encouragement from a great number of individuals. I would like to express my deep appreciation and gratitude to my advisor, Dr. Felicia Lincoln, for the patient guidance and mentorship she provided to me, all the way from when I was first considering applying to the $\mathrm{PhD}$ program in the Curriculum and Instruction, through to completion of this degree. I am truly fortunate to have had the opportunity to work with her.

I would also like to thank my committee members, Dr. Michael Daugherty, Dr. Michael Wavering and Dr. Wen-Juo Lo for their friendly guidance and thought provoking suggestions over the past two years as I moved from an idea to a completed study.

I take this opportunity to express my gratitude to faculty, staff and colleagues in the department of Curriculum and Instruction for their help and support. I am grateful to all my friends who shared their memories and experiences on this journey.

I give deep thanks to Professor Gang Gu, for helping me gain access to the participants in the study. I must acknowledge as well the teachers and students who took part in this study for generously sharing their time and ideas.

Finally, a special thanks to my family. Words cannot express how grateful I am to my parents, my husband, my sister and my son for all of the sacrifices that they've made on my behalf. 


\section{TABLE OF CONTENTS}

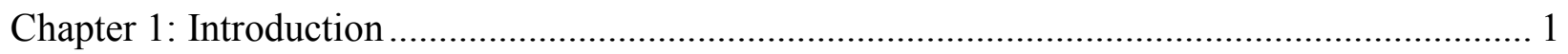

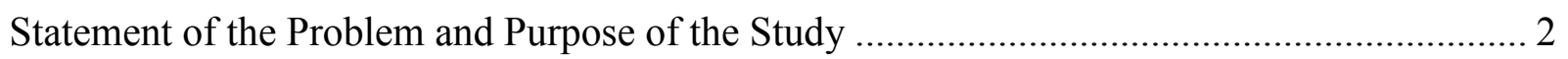

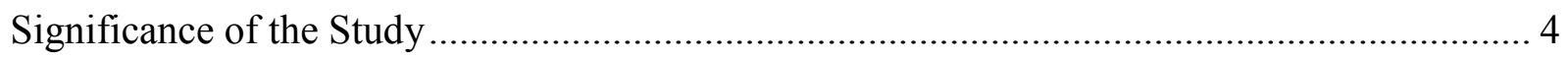

Research Questions and Related Hypotheses ......................................................................... 4

Brief Overview of the Proposed Method ........................................................................... 5

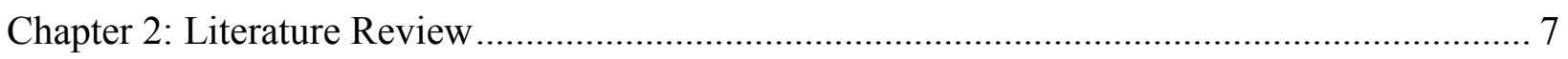

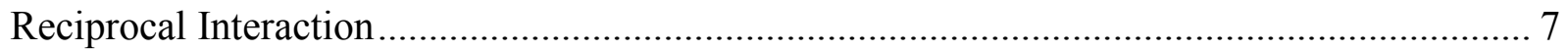

Models of Self-Regulated Learning............................................................................... 9

Constructs of Self-Regulated Learning........................................................................... 13

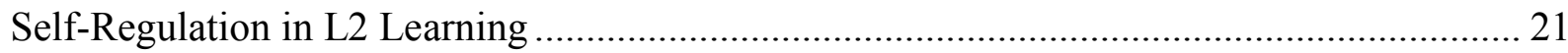

Summary

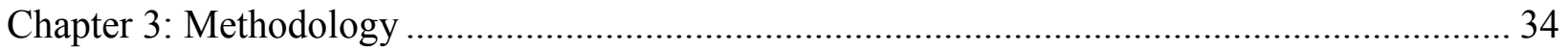

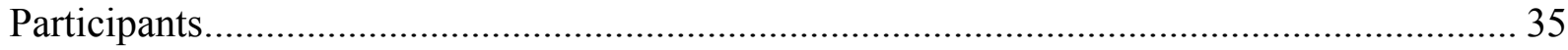

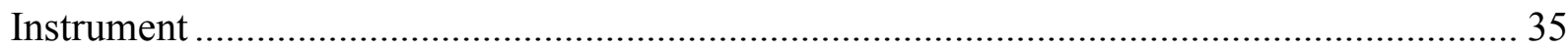

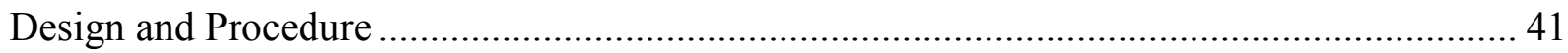

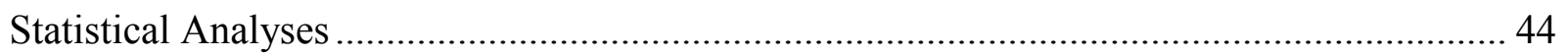

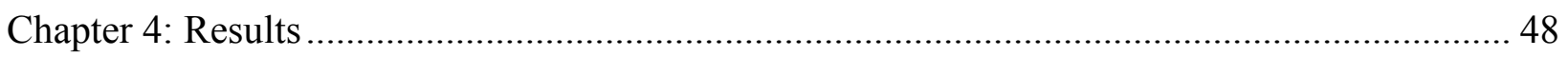

Relationship among the Variables of Self-Regulation Model ................................................... 48

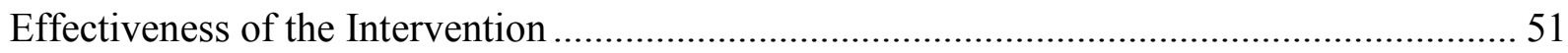

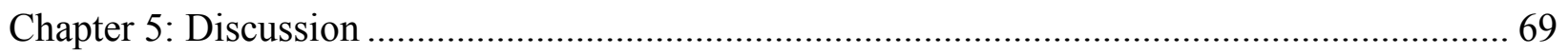

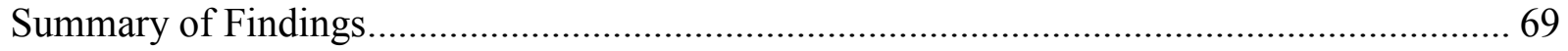

Theoretical and Research Implications .......................................................................... 76

Limitations of the Present Study.................................................................................... 78

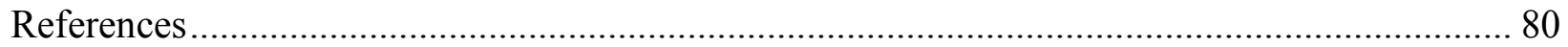

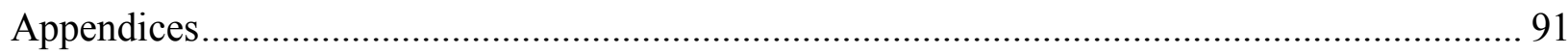

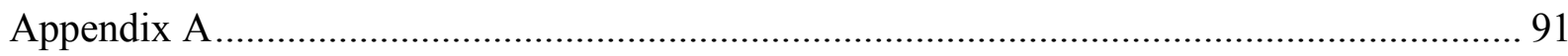

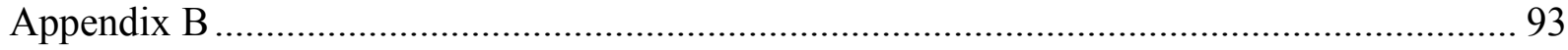

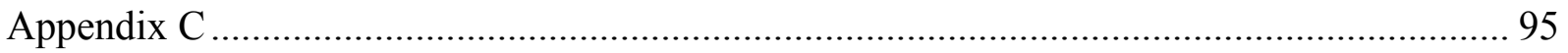

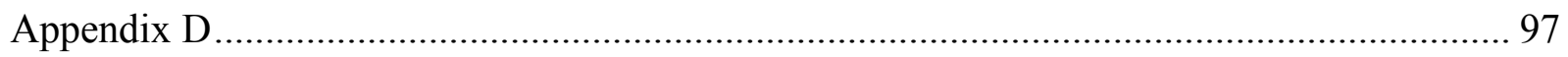

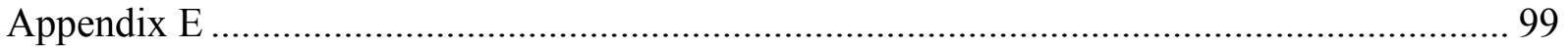




\section{LIST OF TABLES}

Table

$1 \quad$ Overview of Instruments with Subscales.................................. 37

2 Weekly Topics and Outline of Intervention.............................. 44

3 Means and Standard Deviations of Measured Variables.......................... 49

4 Correlations among Measured Variables........................................50

$5 \quad$ Means and Standard Deviations of Motivational Beliefs.......................... 52

6 Means and Standard Deviations of Time and Study Environment Management Skills..................................................... 57

7 Means and Standard Deviations of Overall Language Learning Strategy.......... 59

8 Means and Standard Deviations of Six Categories of Language Learning Strategy................................................................. 61

9 Means and Standard Deviations of L2 Proficiency......................... 67 


\section{LIST OF FIGURES}

Figure

1 Process Model of Self-Regulation........................................ 11

2 Initial Model of Self-Regulated Language Learning........................................... 46

$3 \quad$ Full Path Model Tested with Standardized Path Coefficients.................. 51

4 Significant Time $\times$ Treatment Interaction Obtained in the Analysis of the Intrinsic Goal Orientation Data.............................................. 54

5 Significant Main Effect of Treatment Obtained in the Analysis of the Attribution Data....................................................... 55

6 Significant Time $\times$ Treatment Interaction Obtained in the Analysis of the Self-Efficacy Data................................................... 56

7 Significant Time $\times$ Treatment Interaction Obtained in the Analysis of the Time and Study Environment Management Data............................ 58

8 Significant Main Effect of Time Obtained in the Analysis of the Overall Language Learning Strategy Data..................................... 60

9 Significant Time $\times$ Treatment Interaction Obtained in the Analysis of the Memory Strategy Data................................................ 63

10 Significant Main Effect of Treatment Obtained in the Analysis of the Compensation Strategy Data...

11 Significant Time $\times$ Treatment Interaction Obtained in the Analysis of the Metacognitive Strategy Data. .65

12 Significant Time $\times$ Treatment Interaction Obtained in the Analysis of the L2 Proficiency Data. 


\section{CHAPTER 1}

\section{Introduction}

The shift from behaviorism to cognitivism in educational psychology produced a major change in views of human learning, motivation, and achievement. Recognizing that behavioral theories, which concentrated on human behavior in nonsocial situations, did not offer a complete explanation of human behavior, theorists of psychology began to pay attention to the influence of the social environment on motivation. Rotter (1954) formulated social learning theory that integrates learning and personality theories and offers important insights into the influences on motivation. Based on the earlier theorists' research, Bandura $(1976,1986)$ developed and expanded social cognitive theory by including self-efficacy and self-regulatory processes. Later researchers continued to contribute to the self-efficacy and self-regulation components of Bandura's social cognitive theory. Schunk $(1989,1995)$ presented a model of motivated learning that emphasizes the role of self-efficacy, which refers to personal beliefs about one's capabilities to learn or perform actions at designated levels. Zimmerman $(1989,2000)$ developed a triadic social cognitive model of self-regulated learning in which personal, environmental, and behavioral components influence each other through triadic feedback loops in a cyclical manner. The theoretical background of the study is based on Zimmerman's (2000) cyclical model of selfregulated learning involving three sequential phases: forethought phase, performance phase, and self-reflection phase.

The history of studies on self-regulated learning in education involves three periods: theoretical development, intervention, and operation (Schunk, 2013). During the period of theoretical development (1980s - 1990s), researchers formulated definitions and frameworks, identified key self-regulatory processes, investigated the relationships between self-regulated 
learning and achievement outcome, and developed research methodologies. The period of intervention (1990s - 2000s) was characterized by research investigating methods for teaching self-regulatory processes to students and assessing the strategy training effect. The dominant research model of the period of operation (1990s - today) has addressed the operation of selfregulated learning processes and the reciprocal relationship between self-regulated learning and achievement outcomes.

\section{Statement of the Problem and Purpose of the Study}

According to the context-specific nature of the self-regulated learning process supported by the triadic interaction view, Schunk (2005) suggests that researchers should investigate whether specific course characteristics may moderate the relationships between self-regulation and academic performance, especially the influence of the motivational and affective variables on self-regulated learning of academic skills. Training in self-regulation for students shows significant effects on students' achievement in various academic disciplines and learning contexts, such as reading (Souvignier \& Mokhlesgerami, 2006), writing (Glaser \& Brunstein, 2007), mathematics (Perels, Dignath, \& Schmitz, 2009), science (Lee, Lim \& Grabowski, 2010), special education (Sawyer, Graham, \& Harris, 1992), information technology (Chen, 2002), distance education (Matuga, 2009), and computer-based learning environments (Winters, Greene $\&$ Costich, 2008). Recently, the importance of studying self-regulation as a process has attracted the attention of many researchers (Cleary \& Zimmerman, 2004; Schunk \& Ertmer, 2000).

In the field of second language (L2) learning, researchers and educators seem to regard learning strategies as a component of self-regulated learning, as do psychologists. However, most of them focus on learning strategies, rather than the domain of self-regulation, as psychologists have done (McDonough, 2001). Therefore, in the field of L2 learning, self- 
regulation is a fairly new concept and an exciting development, even though the importance of self-regulated learning was first emphasized in the field of educational psychology more than two decades ago (e.g., Schunk \& Zimmerman, 1998). As the study on learning strategies paved the way toward research on promoting academic achievement and motivation of language learners (Chamot, 2004), language researchers needed to shift the focus from the product (learning strategies) to the process (self-regulatory process) (Dörnyei, 2005) and take language learners' motivational orientations into consideration.

Today students are required to learn in a self-regulated way during and after schooling as well as through their entire working life. College students are especially expected to engage in more independent learning activities outside the classroom. However, college students who struggle in L2 learning might not have the necessary self-regulatory strategies to meet the expectation of independence and autonomy. Some of them may have the issues of low school attendance, decreases in academic motivation, a lack of concentration on learning activities and even academic failure. This fact led to my interest in educational research on improving collegelevel L2 students' self-regulated learning. This study was an intervention program aimed at promoting self-regulated learning in L2 classroom. The training sessions of this study focused on self-regulatory processes such as setting goals; time and study environment management; planning, monitoring and evaluating learning activities; and developing positive self-efficacy and academic attributions (a person's beliefs about causes of academic outcomes). The operation of self-regulated learning processes in the context of L2 learning, and the effectiveness of the selfregulation intervention program for L2 learners were investigated and analyzed. 


\section{Significance of the Study}

Consistent with a contextualist viewpoint, researchers must investigate whether the various motivational variables in self-regulated learning processes operate differently across classroom contexts. This study contributes to the existing literature by examining relationships among selfregulation variables in the context of L2 learning. The new perspective on self-regulation has offered language educators a far broader perspective than previous focuses on learning strategies. By understanding the process of self-regulated learning for L2 learners, language educators may be more familiar with the factors that influence a learner's self-regulation and the strategies they can use to promote self-regulated learning in their classrooms. The significant effects of the intervention program in self-regulated learning for L2 learners show that training language learners to regulate themselves in academic settings can improve their L2 proficiency. Therefore, the instructional implication of the study is that by teaching L2 learners to be more selfregulatory, teachers can expect to be more successful in developing responsible, autonomous, and lifelong language learners.

\section{Research Questions and Related Hypotheses}

The research questions for this study were as follows:

1. What is the relationship among self-efficacy, intrinsic goal orientation, language learning strategies, time and study environment management, causal attribution and learning time, and how these self-regulation components are related to college students' L2 proficiency?

2. What is the treatment effect of the self-regulation intervention program for L2 learners?

The first research question concerns the relationship among various self-regulation variables: self-efficacy, intrinsic goal orientation, language learning strategy, time and study environment management, causal attribution, learning time, and L2 proficiency of college students. Based on 
the literature, it was hypothesized that there are potentially causal influences of self-regulated learning variables across the phases of forethought, performance, and self-reflection. The feedback from the prior phase impacts the adjustments regarding current and subsequent efforts in a cyclical self-regulatory process. Furthermore, student self-regulation influences academic success via the enhancement of motivational variables.

The second research question was to investigate the treatment effect of self-regulated learning training for L2 learners. Previous studies (e.g., Cleary \& Zimmerman, 2004; Schmitz \& Wiese, 2006; Stoeger \& Zigler, 2008) reported that variables of self-regulation such as selfefficacy, goal orientation, learning strategies, time and study environment management, and causal attributions of the students as well as students' achievements in various academic disciplines and learning contexts increased as a consequence of the self-regulation training. For the second research question, it was hypothesized that this study would find the same significant effect of the intervention program in self-regulated learning for L2 learners.

\section{Brief Overview of the Proposed Method}

Participants. The participants in this study were undergraduate students at a university in an Asian country. All of the participants were sophomores majoring in English education. At the time of this study, all participants were enrolled in a required intensive English course. Participation was voluntary. One hundred and twenty students ( 7 males, 5.51\%; 113 females, $94.49 \%$ ) were recruited and randomly assigned to either the experimental group or control group. Participants ranged in age from 18 to 20 years.

Instrument. The battery of instruments included one student background information form, the Motivational Scale of the Motivated Strategies for Learning Questionnaire (MSLQ, Pintrich, Smith, Garcia \& McKeachie, 1991, see Appendix A; MSLQ Chinese Version, Wu \& Cheng, 
1992, see Appendix B), SILL ELL Student Form, Ardasheva \& Tretter, 2013, see Appendix C, SILL Chinese version, Yang, 1992, see Appendix D), standardized English proficiency tests, and structured self-regulation diaries.

Design and procedure. All participants completed three questionnaires and three English language proficiency tests before, during, and after the self-regulation instruction respectively. The experimental group received a self-regulation intervention integrated into a regular intensive English course. The control group used the regular curriculum of the intensive English course. The self-regulation intervention designed for the experimental groups was composed of six weekly two-hour training sessions that focused on the main self-regulatory processes, such as goal setting, self-efficacy, time and study environment management, language learning strategies, and causal attribution. Following each training session, the students in the experimental group received weekly checklists on which they completed two take-home tasks daily: voluntary reading assignments and self-regulation diaries. Therefore, they completed the diaries for a total of six weeks, which was expected to promote their metacognition and knowledge transfer. The questions in the structured self-regulation diaries were directly related to the respective training sessions. The main format of the structured self-regulation diaries was Likert-type scales.

In this study, a quasi-experimental pre-post control design was implemented. The statistical analyses performed in the study include path analysis and repeated measures of ANOVA. To examine the relationship among the variables of self-regulation in the process of L2 learning, path analysis was used to develop a structural model by analyzing the path coefficients among constructs. Repeated measures of ANOVA were used to examine the impact of the intervention on students' self-regulation and L2 proficiency. 


\section{CHAPTER 2}

\section{Literature Review}

What follows is a brief overview of Bandura's social cognitive theory. The introduction of definitions and basic components of self-regulated learning follows this review. The social cognitive model of self-regulated learning developed by Zimmerman is emphasized. Second, key variables in three phases of the self-regulated learning process are discussed, and potential interactions among these variables of self-regulated learning are analyzed. Third, the studies of self-regulated learning in the field of L2 learning are highlighted. Finally, the author summarizes and evaluates the important aspects of the existing body of literature and provides a rationale for this study.

\section{Reciprocal Interaction}

Social cognitive theory stemmed from social learning theory. Bandura led the efforts on social learning theory development beginning in the 1960s. By the mid-1980s, Bandura's research had developed into a comprehensive overview of human cognition in the context of social learning. In 1986, Bandura relabeled his social learning theory as social cognitive theory. His theory focuses on how individuals operate cognitively through their social experiences and how these cognitions then influence behavior and development. The foundation of Bandura's social cognitive theory is reciprocal interaction. In 1976, Bandura developed triadic reciprocal determinism, in which the person, the behavior, and the environment all mutually influence one another in the learning process.

According to his model, motivational factors and self-regulatory mechanisms, rather than just environmental factors, contribute to a person's behavior. Moreover, Bandura (1986) points out that humans have the capacity to proactively control and manage these triadic interactions 
through three classes of sub processes: self-observation, self-judgment, and self-reaction, which play a critical role on students' academic performance.

The concept of self-regulation is a multifaceted construct, as reflected in the numerous theories or frameworks put forth to describe it. Although theories of self-regulation have been extended and applied in a series of contexts (e.g. social relationships, clinical psychology), this literature review focuses on studies of self-regulation as they relate to learning. Therefore, theories and empirical studies of self-regulation included in this paper seek to examine how students become masters of their own learning processes (Zimmerman, 2008).

An inclusive definition of self-regulated learning comes from Zimmerman (1989), who defines students who engage in self-regulated learning as metacognitively, motivationally, and behaviorally active participants in their learning. The definition reflects three main dimensions of self-regulated learning: the metacognitive component is related to planning, setting goals, monitoring, and evaluating, i.e. understanding how to self-regulate; motivation involves taking responsibility for one's successes and failures, which results in increased effort and persistence; and the cognitive element refers to possessing the skills necessary to make appropriate modifications in self-regulation processes. Moreover, Alexander, Graham, and Harris (1998) state that self-regulation involves not only the learner's regulation of cognition but also management of affective states and the social environment, which added the fourth dimension of self-regulated learning: the social-affective element.

Based on the above mentioned constructs, a number of self-report instruments, such as questionnaires or interviews, were developed to measure self-regulated learning during the 1990s. Commonly-used examples are the Learning and Study Strategies Inventory (LASSI; Weinstein, Schulte \& Palmer, 1987), the Motivated Strategies for Learning Questionnaire (MSLQ; Pintrich, 
Smith, Garcia \& McKeachie, 1991, 1993), and the Inventory for Recording Learning Strategies in Academic Studies (LIST; Wild \& Schiefele, 1994). The initial attempts of these interview and questionnaire measures of students' self-regulatory strategies were successful in demonstrating significant predictions of students' course performance (Zimmerman \& Martinez-Pons, 1988).

\section{Models of Self-Regulated Learning}

Besides providing definitions and components of self-regulation, researchers have adapted the concept of self-regulation to the field of learning and developed a number of theories and models of self-regulated learning. Among these theories and models, perhaps the most influential research is Zimmerman's $(1989,2000)$ social cognitive models of self-regulated learning.

A triadic view of self-regulated learning. In accordance with Bandura's (1986) triadic formulation, Zimmerman (1989) proposed the triadic interaction among three components: the person, his or her behavior, and the environment. The personal component involves the observation and adjustment of cognitive and affective states (e.g., beliefs about success), the behavioral component is about the observation and adjustment of performance (e.g., engaging in a task), and the environmental component involves the observation and adjustment of environmental conditions (e.g. feedback from a teacher). The implication of the triadic interaction for researchers is that the impact of variations in context and personal experience should be considered when understanding students' self-regulated learning.

Although research provides evidence on the importance of students' use of self-regulation strategies, in teaching practice, it also indicated that few teachers effectively prepared students to self-regulate their own learning processes (Zimmerman, Bonner, \& Kovach, 1996). Recognizing that students' self-regulated learning processes are trainable through specific experience, researchers were interested, from the 1990 s to the 2000 s, in the intervention studies that aim at 
influencing students' achievement outcomes by teaching students self-regulated learning strategies. Training in self-regulation for students shows significant effects on students' achievements in various academic disciplines and learning contexts, such as reading (Souvignier \& Mokhlesgerami, 2006), writing (Glaser \& Brunstein, 2007), mathematics (Perels, Dignath, \& Schmitz, 2009), science (Lee, Lim \& Grabowski, 2010), special education (Sawyer, Graham, \& Harris, 1992), information technology (Chen, 2002), distance education (Matuga, 2009), and computer-based learning environments (Winters, Greene \& Costich, 2008). Besides fostering self-regulated learning at school, researchers also addressed adult groups, such as college students (Schmitz, 2001) and pre-service teachers (Kramarski \& Michalsky, 2009).

A process-oriented perspective of self-regulated learning. Since the last decade, researchers have begun to investigate the dynamic nature of self-regulated learning and the reciprocal relation between self-regulated learning and achievement outcomes. Zimmerman (2000) proposed a process definition of self-regulated learning which depicts self-regulation as "self-generated thoughts, feelings, and actions that are planned and cyclically adapted to attainment of personal goals" (p. 14). The basic components of the definition of self-regulated learning, such as goal setting, planning, and self-reflection, reflect a process-oriented perspective of self-regulation. By expanding Bandura's (1986) three regulatory sub-processes, selfobservation, self-judgments, and self-reactions, Zimmerman (2000, 2004) developed a process model of self-regulation (see figure 1) involving three cyclical phases: forethought phase processes (task analysis and self-motivation beliefs), performance phase processes (self-control and self-observation), and self-reflection phase processes (self-judgment and self-reaction). The forethought includes processes that precede learning or performance. The performance phase refers to processes that occur during learning efforts or performance. The self-reflection phase 
consists of processes occurring after efforts to learn or perform (Zimmerman, 2000). This process model of self-regulation reveals the structure of self-regulation processes and their relation to important academic motivational beliefs. First, it assumes significant correlations among variables within a particular self-regulated phase. For instance, in the forethought phase, task analysis variables, such as goal setting, are assumed to be significantly related with selfmotivation beliefs, such as self-efficacy. Moreover, because of the dynamic and fluid nature of these components during the learning process, there are potentially causal influences of selfregulated learning processes across phases. The feedback from the prior phase impacts the adjustments regarding current and subsequent efforts in a cyclical self-regulatory process. For example, the self-reflection phase variables, such as self-judgment, can influence forethought phase processes regarding future learning attempts, indicating a cycle of self-regulation.

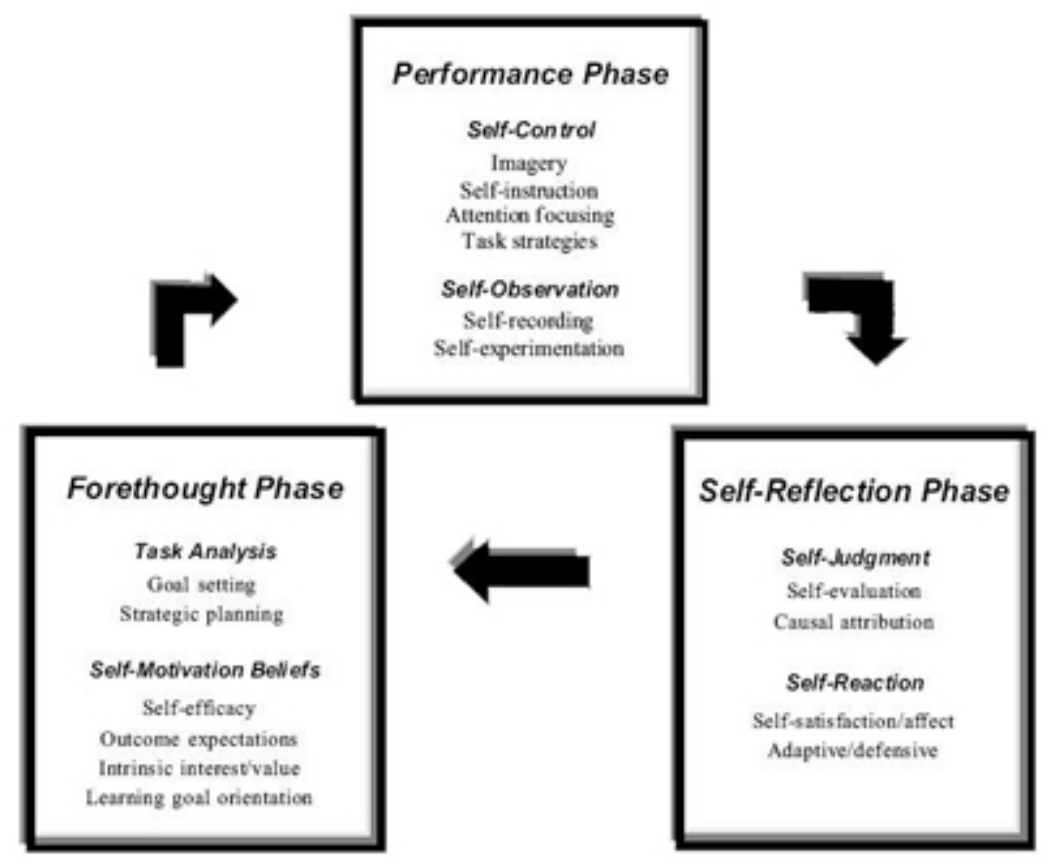

Figure 1: Process model of self-regulation (Zimmerman, 2000, 2004).

The importance of studying self-regulation as a process has been recognized by many researchers (Cleary \& Zimmerman, 2004; Schunk \& Ertmer, 2000). Representative studies of 
measuring self-regulated learning as a process include intervention sessions for adult students designed by Schmitz and Wiese (2006), as well as the training program for elementary students carried out by Stoeger and Zigler (2008). Both were designed on the basis of a process-oriented model of self-regulated learning involving three cyclical phases: forethought phase, performance phase, and self-reflection phase (Zimmerman, 2000). Schmitz and Wiese (2006) conducted four weekly two-hour training sessions of self-regulated learning with a sample of civil engineering students at a German university. The study results indicate that besides improved time management skills, as well as planning and concentration, variables of motivation such as selfefficacy, positive affect, personal understanding, and satisfaction also increased in the students as a consequence of the training. Stoeger and Zigler (2008) studied 219 fourth grade pupils attending German public schools who received classroom-based training of self-regulated learning over a five-week period. Consistent with Schmitz and Wiese's research (2006), the intervention study revealed significant improvement in the following forms of self-regulation and motivation: time management, self-efficacy, interest, willingness to exert effort, and learning goal orientation.

As these studies focus on time course analysis of self-regulation training effects, new methodologies (e.g. think aloud measures, microanalytic measures and diary measures) were implemented along with traditional self-report instruments to capture the dynamic and cyclical nature of self-regulated learning. Schunk (2013) suggests that besides employing those timeintensive measures to assess the operation of self-regulated learning, researchers should also collect achievement outcomes concurrently with those self-regulated learning processes to track the reciprocal relation between self-regulated learning and achievement outcomes. 


\section{Constructs of Self-Regulated Learning}

Regulation of motivation has been identified as a core facet of being a self-regulated learner. Recent efforts have revealed a close relationship between the main self-regulated processes and many sources of motivation during three sequential phases of learning. Given this relationship, how does motivational regulation operate with different phases of self-regulated learning? To support an increased understanding of the process of self-regulation, the next part of the chapter focuses on key variables in self-regulated learning, and this is followed by a discussion of potential interactions among these variables of self-regulated learning. Based on the theoretical model of self-regulated learning developed by Zimmerman (2000), the discussion of the role of variables is organized by three cyclical phases: forethought, performance, and reflection. Three general types of motivational beliefs (self-efficacy, goal orientation, and causal attribution) and learning strategies are highlighted based on their prominence in the literature on self-regulation. More specifically, in the forethought phase, self-efficacy and goal orientation will be discussed. In the performance phase, the various learning strategies, including metacognition, cognition engagement and time management will be discussed. In the reflection phase, causal attribution for performance will be discussed.

Forethought phase. There are two categories of forethought: task analysis and selfmotivational beliefs. Self-efficacy and goal orientation are two key self-motivational beliefs that are active throughout the model.

Self-efficacy. Bandura (1986) defines self-efficacy as "people's judgments of their capabilities to organize and execute courses of action required to attain designated types of performances" (p. 391). In a school context, academic self-efficacy refers to students' confidence in their abilities to bring about positive academic outcomes. Self-efficacy perceptions have 
important implications for students' self-regulation during the forethought phase, such as goal setting, students' choices of activities, efforts and task persistence (Schunk, 1995; Zimmerman \& Cleary, 2009; Zimmerman \& Kitsantas, 1997). Students holding low self-efficacy for accomplishing a particular task may avoid it; those who believe they are capable are likely to be cognitively engaged. The more confident students are in their abilities, the more likely they are to try harder to persist in the face of difficulties than those with doubts.

According to Bandura's triadic reciprocal causation model, the person, the behavior, and the environment all reciprocally interact to create learning in an individual. This model can be exemplified using the concept of self-efficacy. The personal factor (self-efficacy) influences such achievement behaviors as choice of tasks, persistence, and effort. In turn, student behaviors modify self-efficacy. At the same time, environmental factors, such as teacher feedback and parenting, contribute to a person's achievement behavior and further influence the personal factor (self-efficacy). Compared with other expectancy constructs, such as self-concept, self-efficacy is more situation or task specific and more dynamic and changeable. In other words, a student's self-efficacy for a specific task might fluctuate due to the individual's preparation, physical and affective state, and external conditions, such as the nature of the task and teacher feedback. In general, it is most effective to have self-efficacy that slightly exceeds actual skills at any given time (Bandura, 1977). Schunk (1995) has found that important factors for teachers to consider when fostering their students' self-efficacy include modeling solving problems with specific strategies or skills, providing informative feedback, and helping learners achieve academic success by setting challenging, yet manageable, goals.

Goal orientation. Goal-orientation theory is concerned with why individuals want to learn for the goals and how they approach and engage in their tasks. Elliott and Dweck (1988) defined 
an achievement goal as involving a program of cognitive processes that have "cognitive, affective, and behavioral consequences" (p. 11). Researchers have defined and studied two contrasting achievement goal orientations: mastery goal orientation and performance goal orientation (Ames \& Archer, 1988). The purpose of a mastery approach goal is to learn and master the knowledge or new skills to achieve improvement based on self-referenced standards, and a mastery avoid goal involves avoiding misunderstanding and perfectionism. In contrast, a performance approach goal presents a focus on achieving normatively defined success and how ability will be judged relative to others, and a performance avoidance goal is concerned with not appearing incompetent relative to others (Maehr \& Zusho, 2009; Pintrich, 2000). Research evidence suggests that goal orientation is associated with a wide range of motivational beliefs that are important mediators of self-regulated learning. Generally, a mastery goal orientation is related to a positive pattern of attributions, active attitudes toward learning, and higher performance, whereas a performance goal orientation is linked to a maladaptive pattern of attributions and lower motivation and performance (Ames \& Archer, 1988; Pintrich \& Schunk, 1996; Weiner, 1979). When focusing on the forethought phase, goal orientation influences goal setting, choice of activities (Ames \& Archer, 1988; Elliott \& Dweck, 1988), and self-efficacy (Jagacinski \& Nicholls, 1987). For example, mastery approach-oriented students are more likely to choose tasks that will improve their skills and to focus on the strategies they will employ to assure their self-efficacy. In turn, the self-efficacy based on their improvement will reduce their focus on social comparison and help them set more mastery goals in their future learning process. On the other hand, to avoid showing low performance levels, students with a performance goal seek to set easier goals, avoid potential challenging learning experiences, and use escape strategies (Dweck, 1986; Pintrich \& De Groot, 1990). 
Performance phase. As discussed above, three main components of self-regulated learning are important to classroom performance: (1) metacognitive strategies for planning, monitoring, and modifying cognition; (2) cognitive strategies for fostering active cognitive engagement in learning; and (3) motivational beliefs about learning (Zimmerman, 1989). This section focuses on metacognitive strategies and cognitive strategies used during the performance phase and their interactions with two forethought phase motivational beliefs, self-efficacy and goal orientation.

Learning strategies. Weinstein et al (2000) defined learning strategies as "any thoughts, behaviors, beliefs, or emotions that facilitate the acquisition, understanding, or later transfer of new knowledge and skills" (p. 727). Metacognitive strategies have received a great deal of attention in the self-regulation literatures (Flavell, 1979; Schraw et al., 2006; Schraw \& Moshman, 1995). Metacognition is first defined simply as "thinking about thinking" by Flavell (1979, p. 906). Metacognition consists of two components: metacognitive knowledge and metacognitive regulation. Metacognitive knowledge includes knowledge about oneself as a learner, knowledge about tasks, and knowledge about strategies. Metacognitive regulation involves using metacognitive strategies to regulate and supervise learning, to plan and monitor cognitive activities, and to evaluate the efficacy of those activities. For example, when a learner's cognitive goal is to understand reading material, the learner may use the following metacognitive strategies to ensure that he can achieve the cognitive goal. He may plan the task by budgeting time and selecting appropriate strategies. He may monitor his comprehension of the reading material by asking himself some questions and associating new content with previously learned knowledge, and he may evaluate the product of his learning by seeking feedback from other resources and adjusting his goals in time. 
Evidence from empirical studies (Eisenberg, 2010; Graham \& Harris, 2000; Schraw et al., 2006; Whitebread et al., 2009) tends to support the link between learning strategies, motivation, and academic achievement. Furthermore this evidence suggests that students who are able to engage in self-regulated learning by planning, setting goals, monitoring, and evaluating cognitive activities as well as affective states and the social environment, and who use appropriate learning strategies tend to have higher motivations in learning and therefore are shown to have better academic achievement. For instance, Pintrich and De Groot (1990) studied seventh and eighth graders in science and English classes and found a positive relationship between levels of selfregulated skills and academic performance.

Training students in learning strategies, especially metacognitive strategies, shows significant effects on students' achievements in various academic disciplines and learning contexts (Cleary \& Zimmerman, 2004; Guthrie and Wigfield, 2000; Perry and Vandekamp, 2000; Schunk and Zimmerman, 1998). In the aspect of science education, Kramarski and Mevarech (2003) examined the effects of metacognitive training on the mathematical reasoning and metacognitive skills of 384 eighth-grade students. The results show that students involved in metacognitive instruction performed better than students in the control group in the ability to interpret graphs, fluency and flexibility of correct mathematical explanations, use of logical arguments to support math reasoning, and performance on transfer tasks. In a literacy instruction study, Houtveen and Grift (2007) used empirical research to examine the effects of metacognitive strategy instruction on ten-year-old students' reading comprehension. The students in the experimental group performed significantly better on reading comprehension than the students in the control group. 
Interactions between learning strategies and motivational beliefs. Schraw et al. (2006)

defined motivation as "beliefs and attitudes that affect the use and development of cognitive and metacognitive skills" (p. 112). This definition emphasizes the role of cognitive and metacognitive strategies in improving persistence, and effort regulation in the face of challenging tasks. Martinez (2006) argues that the effect of self-regulation on academic success is mediated by motivation.

Much research has demonstrated that motivational components in the forethought phase are significantly related to students' cognitive engagement during the performance phase (Bandura, 1997; Pintrich \& Zusho, 2002; Wigfield et al., 2008). The following examples focus on the interactions between two forethought variables discussed above (i.e. self-efficacy and goal orientation) and learning strategy use. First, research evidence shows that students' self-efficacy beliefs are closely linked to cognitive strategy use and time management in varied school subjects (Britton \& Tesser, 1991; Schunk \& Swartz, 1993; Zimmerman, Bandura, \& MartinezPons, 1992). For example, self-efficacious students were more likely to report use of cognitive strategies and metacognitive strategies and to persist more often at difficult or uninteresting academic tasks than self-doubters (Pajares, 2008). In turn, students' motivation and self-efficacy are enhanced when they acquire self-regulatory strategies and realize they are performing skillfully or becoming more competent (Schunk, 1995). Second, mastery goal orientation causally influences use of cognitive strategies, self-regulation, and task persistence (Pintrich \& De Groot, 1990). Grant and Dweck (2003) further indicated that performance goals predicted strategy use for surface processing of course material and mastery goals predicted more deep processing strategies. 
Reflection phase. Based on the cyclical view of self-regulation (Zimmerman, 2000), students' self-reflection is not only linked to strategic processes and learning outcomes during the previous performance phase, but also impacts how they think about upcoming tasks in the next forethought phase (Zimmerman \& Kitsantas, 1997; Zimmerman \& Kitsantas, 1999; Schunk, 1995).

Causal attribution. Causal attribution, which occurs after performance efforts, is particularly important in the reflection phase of the self-regulated learning process. Attribution is a cognitive theory that is concerned with a person's beliefs about causes of outcomes and how those beliefs influence expectations of the person's behavior. The attributions that people use to explain outcomes can be analyzed in terms of three perspectives: internal and external, stable and unstable, and controllable and uncontrollable (Weiner, 1992). An internal attribution refers to the location of a cause within a person. For example, ability, intelligence, and effort are regarded as personal causes. On the other hand, an external attribution explains causality to an outside agent, such as luck, task difficulty, and instructor. Causal stability indicates whether the causes are temporal or constant. For example, luck is temporal, while ability is constant. Finally, controllability refers to the extent a cause is controlled by a person. For example, one can control some causes such as effort, but not other causes, such as intelligence or luck. Some researchers (Weiner, Russell, \& Lerman, 1979) found emotions elicited in academic achievement contexts are linked with causal beliefs. For example, internal causes of academic success, such as ability and effort, cause pride and confidence. Internal controllable causes of failure (e.g., lack of effort) cause guilt and regret. Internal uncontrollable causes of failure (e.g., low aptitude) lead to shame. Generally, students who attribute causation to internal, changeable, and controllable methods of learning should be more motivated to continue to self-regulate their efforts on future learning. 
Attribution theory has two important implications for academic motivation during the performance phase and forethought phase, respectively. First, self-regulated strategy use during the performance phase influences the types of attributions that students make during the reflection phase (Anderson \& Jennings, 1980; Clifford, 1986). Zimmerman and Kitsantas (1997) found that people who use a specific learning strategy during the performance phase are more likely to attribute negative performance outcomes to strategic sources rather than low ability; this type of attribution is effective in sustaining motivation. As we discussed above, poor strategy choices are external, changeable, and controllable causes; therefore, strategy attributions preserve self-efficacy beliefs much longer than ability or effort attributions. Second, learners' current self-perceptions on the causes of their academic success or failure will strongly influence forethought processes cyclically, such as self-efficacy beliefs and learning goal orientations (Schunk, 1996). When discussing the factors that influence an individual's self-efficacy, Bandura (1986) proposed the reciprocal relationship between self-efficacy and attribution. A student's self-efficacy can be influenced by how he or she explains the academic success or failure. At the same time, a student's attributions for an outcome can also be affected by the level of selfefficacy on a particular task. Some researchers (Chase, 2001; Hsieh \& Schallert, 2008) examined the reciprocal connection between one's self-efficacy and attributions. The whole picture of the relationship between self-efficacy and attribution is that students with high self-efficacy are more likely to make internal and controllable attributions than are students with low self-efficacy. For example, high-efficacy students are more likely to attribute their failure to lack of effort, while low-efficacy students are more likely to attribute their failure to lack of ability. Thus, educators can help students with low self-efficacy make more internal and controllable attribution towards their success and failure and so influence their expectation for future academic success. 


\section{Self-Regulation in L2 Learning}

Learning strategies in L2 studies. Ever since Naiman et al. (1976) noted that "good" language learners appear to use a larger number and range of strategies than "poor" language learners, the implications of understanding strategy use have become increasingly important. The enthusiasm in learning strategies in educational psychology in the 1980s also inspired L2 researchers to embrace the unique significance of learning strategies in promoting academic achievement and motivation of language learners (Dörnyei, 2005). The main research findings in studies of language learning strategies involve defining and classifying language learning strategies, the factors that influence learners' choice of strategies, studies that try to identify correlations between strategy use and L2 achievement, and the attempts of strategy training.

Defining and classifying language learning strategies. For the purpose of defining and classifying language learning strategies, considerable progress has been made in developing definition and taxonomies (Chamot, 1987; O’Malley, 1987; Oxford, 1990; Rubin 1981; Wenden, 1982). The work of Rubin (1981) contributes to the understanding of language learning by identifying a range of cognitive strategies that contribute directly to learning. Wenden (1982) adds an important new dimension to Rubin's understanding of learner strategies - the importance of metacognitive knowledge in L2 learning. Based on Flavell's (1979) framework of metacognition, Wenden examines how learners regulate their learning by planning, monitoring, and evaluating their learning activities and identifies three categories of self-directing strategies: knowing about language, planning, and regulating. O’Malley (1987) provides an expanded list of metacognitive planning strategies used by L2 learners: advanced organizers, directed attention, selective attention, self-management, advance preparation, and delayed production. O'Malley et al. (1985) also clarify the differences between cognitive learnings strategies and metacognitive 
strategies: "Metacognitive strategies involve thinking about the learning process, planning for learning, monitoring for comprehension or production while it is taking place, and selfevaluation of learning after the language activity is completed. Cognitive strategies by contrast are more directly related to individual learning tasks and entail direct manipulation or transformation of the learning materials" $(1985$, p. 506). This line of research suggests that transfer of strategy training to new tasks can be maximized by pairing cognitive strategies with appropriate metacognitive strategies.

According to Oxford (1990), "learning strategies are specific actions taken by the learner to make learning easier, faster, more enjoyable, more self-directed, more effective, and more transferable to new situations" (p. 8). Besides cognitive strategies and metacognitive strategies, Oxford's taxonomy (1990) includes four other categories of learning strategies: memory strategies, compensation strategies, social strategies, and affective strategies. Memory strategies help students store and retrieve information. Compensation strategies help students to use the language despite large gaps in knowledge. These strategies are intended to make up for a lack of knowledge in the areas of grammar and vocabulary. Social strategies help students learn through social interaction, such as asking questions or cooperating with others. Affective strategies help to regulate emotions, motivations, and attitudes, such as lowering one's anxiety or encouraging oneself. The taxonomy of O'Malley and Chamot (1990), which includes three main classes of strategies (cognitive, metacognitive, social/affective strategies), is basically similar to Oxford's taxonomy.

At the initial stage in the history of language learning strategy research, there was no complete agreement on exactly what strategies are, how many strategies exist, and how they should be defined. Despite inconsistencies and discrepancies among various taxonomies, 
considerable progress has been made in classifying strategies. The taxonomies developed by O’Malley and Chamot (1990) and Oxford (1990) provide a basis for studying which strategies or combination of strategies are effective in promoting learning.

Based on Oxford's strategy taxonomy, Oxford (1990) developed the Strategy Inventory for Language Learning (SILL). SILL is most often employed as an instrument for assessing language learning strategy use, especially for foreign language learners (see Cohen, Weaver \& Li, 1996; Oxford, 1990; Wharton, 2000). It has also been used in studies that correlate strategy use with factors such as learning styles, age, gender, proficiency level, and motivation (Bedell \& Oxford, 1996; Ehrman, 1990; Green \& Oxford, 1995; Oxford \& Nyikos, 1989; Wharton, 2000). Although diaries, think-aloud activities and interviews were reported as data collection instruments, in the field of L2 studies, the assessment of learning strategies has been typically relied on self-report questionnaires (Dörnyei, 2005).

Factors affecting language learning strategies. Learning strategies are affected by many factors rather than operating by themselves. These factors then influence two aspects of learning: the rate of acquisition and ultimate level of achievement. The learners' success and their level of L2 proficiency can also affect their choice of strategies. These factors could be divided into two main groups: learner factors and situational factors. Learner factors include: age, sex, nationality/ethnicity, aptitude, cognitive style (such as field dependence/independence), learners' beliefs, affective variables (such as attitude and motivation), and previous learning experience. Situational factors include: language learning context (second versus foreign), language learning task, teaching methodology, and teacher expectations.

Numerous studies have been carried out to examine why and how these factors impact language learning and strategy use. Age eventually emerges as a clear factor affecting the way 
strategies are used. Oxford (1989) reported that older learners use a different range of strategies than younger learners. Some studies (e.g. Ehrman \& Oxford, 1990) indicate that males and females use very different language learning strategies, and females may use a wider range of strategies than males. Nationality or ethnicity influences strategy use; for example, Hispanics seem to use social strategies more than some other ethnic groups. Learners who are more advanced seem to use better strategies (Chamot, 1987; O’Malley et al., 1985). Language aptitude affects the nature and frequency of strategy use (Skehan, 1989). General learning style is a strong factor on the language learners' choices of learning strategies (Oxford, 1989). More highly motivated learners use a significantly greater range of appropriate strategies than do less motivated learners (Oxford \& Nyikos, 1989). A systematic assessment of learners' beliefs would greatly facilitate learning in ESL classrooms (Bialystock, 1981). Task requirement and teachers' expectations, expressed through classroom instructional and testing methods, strongly shape learners' strategies (O’Malley et al., 1985; Chamot, 1987). For instance, classroom emphases of grammar learning and of error correction encourage development of learning strategies like analysis, monitoring, and reasoning rather than learning strategies for developing communicative competence. The cultural values of the learner's society also have a strong influence on choice and acceptability of language learning strategies (Chamot, 2004). For example, in order to be successful in finishing competitive tasks, language learners in a culture that focus individual competition may prefer strategies that allow them to work alone rather than using social strategies such as collaboration with others.

To sum up, there is evidence to suggest that a number of learner factors and situational factors are related to strategy use of L2 learners. The educational implication of understanding the factors that influence strategy use is very important. To facilitate students' learning strategy 
use and L2 proficiency, language teachers and researchers should collect on a more routine basis some information on learner factors and learning environment factors.

Correlations between strategies use and L2 proficiency. As researchers in cognitive psychology, applied linguists tried to understand self-regulated learning by linking learning strategies with L2 proficiency and academic motivation (Randi \& Corno, 2000). The overall research result in the field of L2 learning is consistent with previous research literature in other academic fields. Successful learners appear to use learning strategies more frequently and in qualitatively different ways than learners who are less successful; different kinds of learning strategies may contribute to different aspects of L2 proficiency; learners need to employ strategies flexibly by selecting those strategies that are appropriate for performing a particular learning task (Cohen \& Macaro, 2007; Ellis, 1994; Green \& Oxford, 1995). Metacognitive learning strategies are vital for language learning because they develop into necessary skills for self-directed learning (Oxford, 1990). English as Second Language (ESL) learners with better metacognitive self-regulation of their cognitive activities use more appropriate learning strategies to promote effective language learning. Moreover, self-regulation of social-affective factors makes ESL learners experience more positive social relationships at school, which in turn increases their level of engagement and academic motivation and therefore produces better academic achievement (Oxford and Ehrman, 1993; Schmidt et al. 1996). Since the mid-1990s, researchers (e.g., MacIntyre, 1994; Schmidt \& Kassabgy, 1996) in the field of L2 learning have been interested in the relationship between language learning strategy use and academic motivation. For example, Schmidt and Watanabe (2001) investigated around 2,000 American college students and found that motivation affects strategy use across various strategy types. Motivation affects cognitive and metacognitive strategy use most and affects social strategy use 
least. Additional support is from Feng (2010), who investigated the relationship between language learning motivation and the choice of language learning strategies among Chinese college students. The students' motivation was found to significantly correlate with their learning strategy use. That means the more motivated the learners are to learn English, the more frequently they report using strategies.

Attempts at strategy training. In the late 1990s, there was a shift from simply identifying, describing, and classifying useful language learning strategies to interventionist studies aimed at training learners to be better at the learning and use of language. McDonough (1995) divides the research on language learning strategies into descriptive studies and interventionist studies. He then further divides the interventionist studies into general ones aimed at teaching strategies for overcoming a number of learning problems encountered in several aspects of language learning and specific ones attempting to teach particular strategies, for instance, reading comprehension or listening comprehension. Most interventionist studies support the concept that strategy training is helpful in L2 learning, and a fair number of learners receiving strategy training have shown greater improvement in language performance than those who were not trained in strategy use (Chamot, 2005; Oxford et al. 1990). For instance, through relating the learners' improvement on certain language tasks to the strategy training they received, O'Malley and Chamot (1990) claim that strategy training is effective for listening and speaking. The study uses natural classroom instruction so that the instruction procedures could be generally applied by most teachers. The implication of these findings is that learning strategies are trainable and important language strategies can be taught in ESL classrooms to promote language proficiency.

Models of strategy-based instruction. The goal of strategy training is to explicitly teach students how, when, and why strategies can be used to facilitate their efforts at learning a foreign 
language. Teaching strategies does not mean that teachers have to design a particular workshop or training session to teach a series of strategies lessons. In fact, there are numerous approaches available for strategy training, such as general study skills courses, peer tutoring, researchoriented training, videotaped mini-courses, awareness training, and integration of strategies into second or foreign language instruction (Cohen, Weaver, \& Li, 1996). Most researchers agree that learning strategy instruction should be integrated directly into the instructional plan. Strategybased instruction is an approach that incorporates strategy instruction into the regular curriculum and includes strategy training as a natural part of ESL class activities. This approach has two major components: (1) develop a strategy list, and teach students explicitly how, when, and why these strategies can be used to facilitate their language proficiency; (2) integrate strategies into everyday class materials, and explicitly or implicitly embed strategy training into the language tasks. In this way, the teachers set learning objectives on both the language skills and the learning strategies in their ESL classrooms. Although it may seem that in-class strategy training takes valuable time away from teaching the language content, teachers who have used this approach have reported that their students become more efficient in completing classroom language tasks, take more responsibility for self-directing their learning out of class, and gain more confidence in their ability to learn and use the target language, so this should compensate for the outlay of time in training them.

Strategy-based instruction follows an organized sequence of steps that scaffold students to acquire learning strategies and move on to apply learning strategies in language tasks independently. A variety of strategy-based instruction models have been developed (Anderson, 2002; Chamot \& O’Malley, 1994; Cohen, 1998; Cohen \&Weaver, 2005; Oxford, 2011).The following are some examples of strategy-based instruction models used in ESL classrooms. 
Chamot and O'Malley (1994) developed a comprehensive and highly explicit strategy-based instructional model, Cognitive Academic Language Learning Approach (CALLA), for L2 learners. The goals of CALLA are for students to learn essential academic content and language and to become independent and self-regulated learners through their increasing command over a variety of strategies for learning in school. The CALLA model extends the strategy-based instruction by connecting it to content area studies. Therefore, there are three components in the CALLA model: integrating the instruction into topics from the major content subjects, developing academic language skills, and explicit training in using learning strategies for academic tasks. It has been used not only in ESL classrooms but also in bilingual and mainstream education classrooms. A typical lesson plan based on the CALLA instructional model includes three objectives: content, academic language, and learning strategies. The instructional sequence suggested by CALLA is a five-phase recursive cycle, which includes preparation, presentation, practice, self-evaluation, and expansion. Through the fives phases, teachers' roles in teaching, modeling, and scaffolding strategies gradually fades so that students can take on more responsibility in choosing, practicing, evaluating, and transferring their learning strategy use.

Anderson (2002) emphasizes the importance of metacognition and provides a model for the use of metacognitive strategies in strategy instruction. He summarizes that teachers should model strategies for learners to follow in five areas of metacognition: preparing and planning for learning; selecting and using learning strategies; monitoring strategy use; orchestrating various strategies; and evaluating strategy use. He also points out, "rather than focus students' attention solely on learning the language, L2 teachers can help students learn to think about what happens 
during the language learning process, which will lead to the development of stronger learning skills" (p3).

Based on the previous study (Cohen, 1998) on the models of strategy-based instruction, Cohen and Weaver (2005) developed a styles- and strategies-based approach that takes students' learning-style preferences into consideration. They identify five steps as the core components of the styles- and strategy-based instruction model: (1) strategy preparation (identifying students' prior knowledge and the strategies they have already developed); (2) strategy awareness-raising (helping students to realize the strategies they might never have thought about or may have thought about but never used); (3) strategy instruction (explicitly describing, modeling, and illustrating potentially useful strategies); (4) strategy practice (providing students ample opportunities to reinforce the strategies they have learned); and (5) personalization of strategies (by encouraging students to evaluate their strategy use and to transfer the use of these strategies to other contexts).

Despite differences that distinguish one instruction model from another, these models share a number of features, such as emphasis on developing metacognitive strategies, explicit integration of strategy training into regular classroom activities, and promotion of learner autonomy. Cohen (1998) claims that strategy-based instruction is considered by a growing number of experts to be the most natural, most functional, in some ways least intrusive, and potentially most supportive means of getting the message to learners that they mobilize their own strategy repertoire. In teaching practice, strategy-based instruction has already been widely advocated in many contexts to help students become more successful in their efforts to learn and communicate in second or foreign languages. For example, Mendelsohn (1994) conducts strategy-based instruction on improving ESL learners listening comprehension. Cohen, Weaver, 
and Li (1996) investigate the benefits of providing L2 learners with formal training in the applications of strategies for speaking. Gu (2007) uses Chamot et al.'s (1999) CALLA framework to integrate strategy training into a writing curriculum in Singapore. Zhang (2008) designed an experiment study to use strategy-based instruction to improve English as Foreign Language (EFL) students' academic reading proficiency. Numerous empirical studies have examined the effects of strategy-based instruction on improvements in student academic performance (Anderson, 2005; Gu, 2007; Mendelsohn, 1998; Thompson \& Rubin, 1996). Generally speaking, strategy-based instruction that focuses on metacognitive strategies shows positive impact on student performance (Graham \& Macaro, 2008). Higher proficiency learners seem to benefit more from strategy-based instruction than lower proficiency students ( Plonsky, 2011). Strategy-based instruction facilitates the development of both language ability and learner autonomy (Nguyen and Gu, 2013). Overall, strategy-based instruction seems to be a plausible route both in developing metacognition and autonomy and in improving language learning performance.

Learning strategy and self-regulation. Although numerous learning strategy instruction programs have been undertaken to help learners to achieve autonomy, few training programs in the field of L2 teaching and learning have studied self-regulation as a process (Victori \& Lockhart, 1995). Therefore, in the field of L2 learning, self-regulation is a fairly new concept even though the importance of self-regulated learning was first emphasized in the field of educational psychology more than two decades ago (e.g., Schunk \& Zimmerman, 1998). There are different terms for the models of learner self-regulation applied to L2 learning, such as "learner self-direction" (Dickinson, 1987), "self-regulated or autonomous L2 learning” (Oxford, 1999), and "learner self-management" (Rubin, 2001). Cohen (1990) defined self-regulated 
learning as an approach in which "learners make decisions, alone or with the help of others, about what they need or want to know, how they will set objectives for learning, what resources and strategies they will use, and how they will assess their progress" (p. 10).

As the study on learning strategy paved the way toward research on promoting academic achievement and motivation of language learners (Chamot, 2004), researchers increasingly recognized the existence of self-regulatory process and the specific capacities underlying it. For example, Chamot and Rubin (1994) indicate that "the good language learner cannot be described in terms of a single set of learning strategies but rather through their ability to understand and develop a personal set of effective strategies" ( p. 372). Thus some researchers began shifting the focus from the product (learning strategies) to the process (self-regulatory process) (Dörnyei, 2005). Some strategy instruction programs have taken learners' motivational temperature into consideration (Cohen and Weaver, 2005). Although language educators seem to regard learning strategies as a component of self-regulated learning as psychologists do, most of them focus on learning strategies rather than on the domain of self-regulation as psychologists have done (McDonough, 2001).

\section{Summary}

As stated throughout the literature review, empirical research supports that student selfregulation influences academic success via the enhancement of motivation. However, assessment of self-regulation is challenging because it is a dynamic capability that varies across specific contexts. Despite the large amount of information that is currently available on how students regulate their learning in the classroom, the literature, especially in the field of L2 learning is by no means comprehensive. 
One of the limitations of the studies in literature lies in the challenges in capturing the complex, dynamic, and highly contextualized nature of self-regulation in learning. Most of the studies rely on quantitative research methods to investigate the relationship between the selfregulation and other constructs, such as motivation, learning strategies, metacognition, and academic performance. Winters et al. (2008) point out that self-regulation and self-regulated learning are often assessed with self-reports from learners, so the reliability and validity of the measurement are questionable. Moreover, as recommended by Schunk (2008), researchers should develop context-specific measures and collect more reliable and valid data by observing the learners' actual use of self-regulatory strategies in their academic tasks. Zimmerman's (2000) process model of self-regulated learning provides an important theoretical framework guiding the development of microanalytic methodology to address various self-regulatory components during the different phases (Cleary, Callan \& Zimmerman, 2012). Recent studies of measuring self-regulated learning as a process (e.g., Schmitz \& Wiese, 2006) focus on time course analysis of self-regulation training effects, which indicates that new methodologies (e.g. think aloud measures, microanalytic measures, and diary measures) should be implemented along with traditional self-report instruments to capture the dynamic nature of self-regulated learning.

Moreover, there are some areas in which further empirical research is needed. For example, there are very few studies that systematically examine how far elements of self-regulation differ by gender and ethnicity. The limited literature on whether gender and ethnic differences are related to self-regulation is inconsistent and inconclusive (Pintrich and Zusho, 2007).

With respect to instructional practice, researchers have shown that training learners to regulate themselves in academic settings can improve their academic performance (Cleary \& Zimmerman, 2004). Responding to the call for research in different contexts, this research was 
undertaken in a L2 learning context. The purposes of the study were to investigate the process of self-regulated learning and the effects of an intervention program on self-regulated learning designed for college L2 learners. 


\section{CHAPTER 3}

\section{Methodology}

This chapter is divided into five sections. First, the research questions and hypotheses are stated. Second, the characteristics of participants are described. Third, the psychometric properties of each instrument are described. The Motivated Strategies for Learning Questionnaire (MSLQ, Pintrich, Smith, Garcia \& McKeachie, 1991; MSLQ Chinese Version, Wu \& Cheng, 1992) was used to measure motivational orientation. The Strategy Inventory for Language Learning (SILL ELL Student Form, Ardasheva \& Tretter, 2013; SILL Chinese version, Yang, 1992) was used to measure language learning strategy use. A national English language standardized test was used to measure language proficiency. Then, procedures are described about how data was collected. Finally, the statistical analyses performed in the study are introduced.

The first research question concerned the relationship among self-regulation variables: selfefficacy, intrinsic goal orientation, attribution, language learning strategy, time and study environment management, and L2 proficiency of college students. Based on the literature, it was hypothesized that there are potentially causal influences of self-regulated learning variables across phases. The feedback from the prior phase impacts the adjustments regarding current and subsequent efforts in a cyclical self-regulatory process. Furthermore, student self-regulation influences academic success via the enhancement of motivational variables.

The second research question was to investigate the treatment effect of self-regulated learning training for L2 learners. Previous studies (Cleary \& Zimmerman, 2004; Schmitz \& Wiese, 2006; Stoeger \& Zigler, 2008) reported that various variables of self-regulation such as self-efficacy, goal orientation, learning strategies, and attributions in the students as well as 
students' achievements in various academic disciplines and learning contexts increased as a consequence of the self-regulation training. For the second research question, it was hypothesized that this study would find the same significant effect of the intervention program in self-regulated learning and academic achievements for L2 learners.

\section{Participants}

The participants in this study were college students at a university in an Asian country. All of the participants were sophomores majoring in English education. At the time of this study, all participants were enrolled in a required university English intensive course. The participation was voluntary. One hundred and twenty-seven students (7 males, 5.51\%; 120 females, 94.49\%) were recruited and randomly assigned to either the experimental group $(n=63,4$ males and 59 females) or control group ( $n=64,3$ males and 61 females). Due to incomplete data, however, seven participants had to be excluded, leaving a final number of 120 participants ( 7 males, 5.83\%; 113 females, $94.17 \%$ ) for the analyses. There were 60 in the experimental group (4 males and 56 females) and 60 in the control group (3 males and 57 females). Due to the small dropouts rate $(.05 \%)$, an imputation was not used to deal with the missing data. This was below the suggested guideline of 5\% (Nosal \& Nosal, 2003). Participants were all Asian, and they ranged in age from 18 to 20 years. As they were enrolled the same courses in each semester, study-related time requirements are comparable across study period. Most students reported having little or no experience with self-regulated learning skills or language learning strategies.

\section{Instrument}

The battery of instruments included one student background information form, the Motivational Scale of the Motivated Strategies for Learning Questionnaire (MSLQ, Pintrich, Smith, Garcia \& McKeachie, 1991; MSLQ Chinese Version, Wu \& Cheng, 1992), the Strategy 
Inventory for Language Learning (SILL ELL Student Form, Ardasheva \& Tretter, 2013; SILL Chinese version, Yang, 1992), College English Test (CET), and structured self-regulation diaries. Some subscales of the instruments were selected to measure the critical variables correspond to the two research questions in the study. An overview of these variables was given in Table 1. 
Table 1

Overview of Instruments with Subscales

\begin{tabular}{|c|c|c|c|}
\hline Instrument & Scale & $\begin{array}{l}\text { Number } \\
\text { of items }\end{array}$ & Range \\
\hline \multicolumn{4}{|l|}{$\mathrm{MSLQ}^{\mathrm{a}}$} \\
\hline & Intrinsic goal orientation & 4 & $7-28$ \\
\hline & Attribution/Control of learning beliefs & 4 & $7-28$ \\
\hline & Self-efficacy & 8 & $8-56$ \\
\hline & Time and study environment management & 8 & $8-56$ \\
\hline \multirow[t]{7}{*}{ SILL $^{b}$} & Language learning strategy (total) & 28 & $28-140$ \\
\hline & Memory strategy & 7 & $7-35$ \\
\hline & Cognitive strategy & 5 & $5-25$ \\
\hline & Compensation strategy & 5 & $5-25$ \\
\hline & Metacognitive strategy & 4 & $4-20$ \\
\hline & Affective strategy & 3 & $3-15$ \\
\hline & Social strategy & 4 & $4-20$ \\
\hline $\begin{array}{c}\text { Learning } \\
\text { diaries }\end{array}$ & Learning time & $\mathrm{N} / \mathrm{A}$ & $\mathrm{N} / \mathrm{A}$ \\
\hline $\mathrm{CET}^{\mathrm{c}}$ & English proficiency & 30 & $0-35$ \\
\hline
\end{tabular}

Note. ${ }^{\mathrm{a}} \mathrm{MSLQ}$ is the Motivated Strategies for Learning Questionnaire. ${ }^{\mathrm{b}} \mathrm{SILL}$ is the ELL student form version of the Strategy Inventory for Language Learning. ${ }^{\mathrm{c} C E T}$ is the College English Test. 
Student background information form. The background information form included sex, age, reasons and goals of taking English courses, years of learning English, and experiences in English-speaking learning environments.

Motivated Strategies for Learning Questionnaire (MSLQ). The MSLQ (Pintrich, Smith, Garcia \& McKeachie, 1991)is a widely used self-report instrument in the research literature regarding self-regulated learning (Duncan \& McKeachie, 2005). It consists of 81 self-report items divided into two main sections: motivation section and learning strategy section. The motivation section contains six subscales representing intrinsic goal orientation, extrinsic goal orientation, task value, control of learning beliefs, self-efficacy for learning and performance, and test anxiety. The learning strategy section includes nine subscales which measure strategies of rehearsal, elaboration, organization, critical thinking, metacognitive self-regulation, time and study environment management, effort regulation, peer learning, and help seeking. According to the MSLQ manual (Pintrich et al., 1991), these subscales can be used together or singly depending on the needs of the researcher. The 81 items presented on a 7-point Likert scale with higher scores indicating greater motivation. To complete these items, participants rate themselves on a 7-point visual analog scale, 1 for "not at all true of me" and 7 for "very true of me". Scores for each subscale are calculated by taking the mean of the items that make up the subscale (Pintrich et al., 1991).

The MSLQ has gone through many revisions and refinements, and have been shown to have adequate reliability and validity when used with college students in the United States (Garcia \& Pintrich, 1994; Pintrich et al., 1993). The internal consistency reliability of the motivation section of the MSLQ, as reported in the MSLQ manual (Pintrich et al., 1991), was between .62 and 93. Predictive validity was demonstrated by the significant scale correlations with final 
grade. Based on the results from factor analyses, factor validity for the MSLQ scales was also claimed by Pintrich et al. (1991). Researchers have recently shown interest in the applicability of this instrument to L2 learning research and found that the reliability of the MSLQ in the context of L2 learning is similar to other school subjects and the MSLQ has the potential to be applied to L2- related studies (Huang, 2008; Stoffa, Kush \& Heo, 2011).

Beyond English, the MSLQ has been widely translated into other languages, such as Chinese (Wu \& Cheng, 1992), Korean (Bong, 2001), and German (Neber \& Heller, 2002). In this study, taking the participants' native language into account, the MSLQ Chinese Version (Wu \& Cheng, 1992) was used to measure students' motivational orientation. Wu and Cheng (1992) reported that their Chinese translation of the MSLQ showed satisfactory reliability and validity. The Cronbach's alpha coefficient for motivation section was .82 . The results of confirmatory factor analyses showed that the theoretical constructs of the Chinese translation supported the original MSLQ. The translation by Wu and Cheng (1992) was done in the traditional Chinese characters. The researcher in this study switched the traditional Chinese characters to the simplified Chinese characters for the participants of this study. Certain words in the translations were modified into standard mandarin to pertain to the participants.

Strategy Inventory for Language Learning (SILL). The SILL (Oxford, 1990) is the most influential instrument in assessing language learning strategies, especially for foreign language learners (Cohen, Weaver \& Li, 1996; Oxford, 1990; Wharton, 2000). It has also been used in studies that correlate strategy use with factors such as learning styles, age, gender, proficiency level, and motivation (Bedell \& Oxford, 1996; Chamot et al., 1987; Ehrman, 1990; Green \& Oxford, 1995; Oxford \& Nyikos, 1989; Wharton, 2000). 
The SILL is based on the Oxford's (1990) language learning strategy system, which includes two main classifications: direct strategies and indirect strategies. It consists of three subscales measuring direct language learning strategies (cognitive, memory, and compensation strategies) and three subscales measuring indirect language learning strategies (metacognitive, affective, and social strategies). The 50 items presented on a five-point Likert scale with higher scores indicating higher frequency of strategy use.

The ESL/EFL SILL has performed well in validity and reliability testing (Oxford \& BurryStock, 1995). The predictive validity is supported by the evidence about the relationships between the SILL and L2 proficiency (Green and Oxford, 1995; Oxford \& Burry-Stock, 1995). Cronbach's alpha coefficient was .94 for the entire scale, and $.75, .84, .69, .86, .68$, and .78 for the six sub scales: cognitive, memory, compensation, metacognitive, affective, and social strategies (Hsiao \& Oxford, 2002). The reliability of the ESL/EFL SILL is slightly lower when it is administered in English rather than the respondent's native language.

Ardasheva and Tretter (2013) addressed the above potential limitations associated with typically lower reliability estimates when the instrument is administered through a nonnative language to groups of English language learners, and modified the 50-item ESL/EFL SILL into the 28-Item SILL ELL Student Form (Ardasheva \& Tretter, 2013). The results of confirmatory factor analyses indicated a good fit to the validation $(\mathrm{GFI}=.92, \mathrm{CFI}=.93$, RMSEA $=.04$, SRMR $=.05)$. The 28-Item SILL ELL Student Form uses a choice of five Likert-scale responses for each strategy described: never or almost never true of me, generally not true of me, somewhat true of me, generally true of me, and always or almost always true of me. Considering the participants in the study were English language learners, the 28-Item SILL ELL Student Form (Ardasheva \& Tretter, 2013) was selected to measure the participants' language learning strategy 
use. The Chinese translation of the 28 item were chosen from the Chinese version of SILL (Yang, 1992), which produced Cronbach alpha reliability coefficients .94. Again, the traditional Chinese characters were switched to the simplified Chinese characters and minor changes were made to make the questionnaire more suitable for the participants of the study.

College English Test (CET). The CET was used to measure the participants' English proficiency in this study. The CET is a large-scale standardized test administered nationwide by the National College English Testing Committee on behalf of the Higher Education Department of the Ministry of Education in China. It aims at measuring the English proficiency of college/university undergraduate students in accordance with the College English Teaching Syllabus. The CET-Band 4 is usually taken by undergraduate students in China to fulfill their graduation requirements and to stand a better chance in the job market (Cheng, 2008). The CET is reported to have maintained high reliability and validity (Jin, 2005; Yang and Weir, 2001).

Structured diary. Structured diary was used to enhance the effect of self-regulated learning. The questions in the structured self-regulation diaries were developed directly related to the respective training sessions. The main format of the structured self-regulation diaries was Likerttype scales. Therefore, it could be used to track the components of self-regulated learning over time. Meanwhile, the process of answering questions in a learning diary regularly at home can stimulate students' metacognitive thoughts as well as enhance the transfer of the training contents presented in classrooms to the actual learning situation at home (Schmitz \& Wiese, 2006).

\section{Design and Procedure}

Pre, mid and post meetings. At the beginning of the 2014 fall semester, all participants took part in a pretest-meeting. The researcher read a brief instruction of the research procedure and requested the students' consent in the study. The participants took about 40 to 60 minutes to 
complete a background information form and two questionnaires: the MSLQ (MSLQ, Pintrich, Smith, Garcia \& McKeachie, 1991; Chinese Version, Wu \& Cheng, 1992) and ESL/EFL SILL (28-Item Student Form, Ardasheva \& Tretter, 2013; SILL Chinese version, Yang, 1992). Then the participants took about 60 minutes to complete a pre-test (CET) on their L2 proficiency. After this meeting, the participants were randomly assigned to either the experimental group or the control group. The experimental group was further divided into two smaller groups to support efficient training effects. The students in the experimental group received a six-week self-regulation intervention integrated into a regular intensive English course. The control group used the regular curriculum of the same intensive English course. Four weeks and eight weeks later, at the mid-meeting and posttest-meeting, all participants filled out the same questions and took tests (CET) on their L2 proficiency.

Intervention package based on the self-regulation model. A self-regulation intervention package was incorporated into an intensive English course. The main goal of the intervention program was to enhance learning results through self-regulated learning training. The intervention design reflected a causal sequence, Intervention $\rightarrow$ Self-Regulated Learning $\rightarrow$ Achievement Outcomes, as well as helped to clarify the selection of training contents. In other words I tried to affect students' L2 proficiency indirectly by influencing related variables of the forethought phase (e.g., setting goals, self-efficacy), the performance phase (e.g., time and study environment management skills such as procrastination and concentration, and language learning strategies such as making prediction and monitoring learning progress), and the reflection phase (e.g., academic attribution). The intervention was composed of six weekly two-hour training sessions that focus on five main variables of self-regulatory process: goal setting, self-efficacy, time and study environment management, language learning strategies, and attribution. At the 
first session, the purpose of the self-regulation intervention, the self-regulation model, and the diary approach were introduced. Immediately after each training session, the students in the experimental group received weekly checklists on which they complete two take-home tasks daily: voluntary reading assignments and self-regulation diaries. Therefore, they completed the diaries for a total of six weeks.

The six self-regulation sessions generally followed a same instruction model. The instruction model was developed based on the styles- and strategies-based approach (Cohen \& Weaver, 2005). The model included five steps: preparation, awareness raising, instruction, practice, and personalization. These sources for training sessions included the six core concepts of the intervention along with handout materials, classroom activities for the students, and structured diaries. The six concepts taught and discussed during the intervention were as follows: (1) selfregulation, (2) Goal orientation, (3) Self-efficacy, (4), Time and study environment management, (5) Language learning strategies, and (6) Attribution. These concepts were related to variables which were measured by the instruments discussed above. Weekly topics and an outline of the six week intervention are listed in Table 2. The concepts of the intervention were integrated into their regular intensive English class, which helped them further apply the material. Students had opportunities throughout the intervention to actively participate by answering questions and cooperating with peers. In addition, the activities in which the students engaged helped them apply the information on a personal level and helped them reflect on their own learning. 
Table 2

Weekly Topics and Outline of Intervention

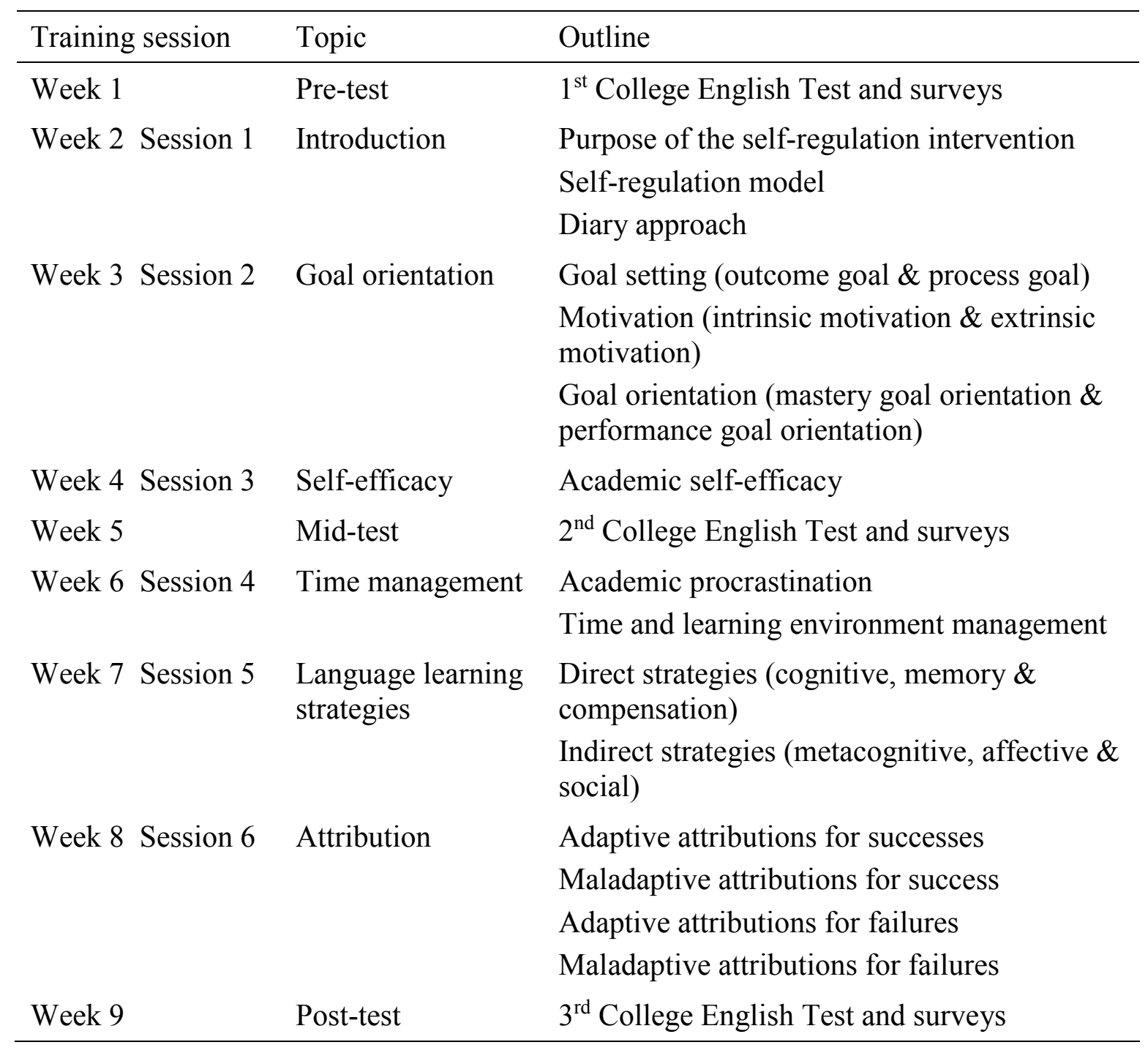

\section{Statistical Analyses}

In order to test hypotheses as stated in the earlier part of the chapter, two set of statistical analyses were performed. The first set of analyses involved the use of path analyses to examine the possible relationships among the variables identified as having an effect on students' L2 
proficiency. The second set of analyses involved the use of repeated measures of ANOVA to examine the treatment effect of self-regulated learning training for L2 learners.

Path analysis. It was hypothesized that there are potentially causal influences of selfregulated learning variables across phases. The feedback from the prior phase impacts the adjustments regarding current and subsequent efforts in the self-regulatory process (see Figure 2). Furthermore, student self-regulation influences academic success via the enhancement of motivational variables. Path analytic techniques were selected because it allow me to move beyond simple or multiple correlations to testing the causal ordering of these variables that is hypothesized on the basis of self-regulation theory. It also allows for the testing of a model and both direct and indirect effects on some outcomes. The exogenous variables in this study include intrinsic goal orientation, self-efficacy, and attribution. The endogenous variables are language learning strategy, time and study environment management, learning time and L2 proficiency. Path analysis was conducted on the following two steps: first, formulation of the hypothesized model based on the consensus of finding from theories and literature reviews; second, computation of path coefficients and assessments of the model fit. 


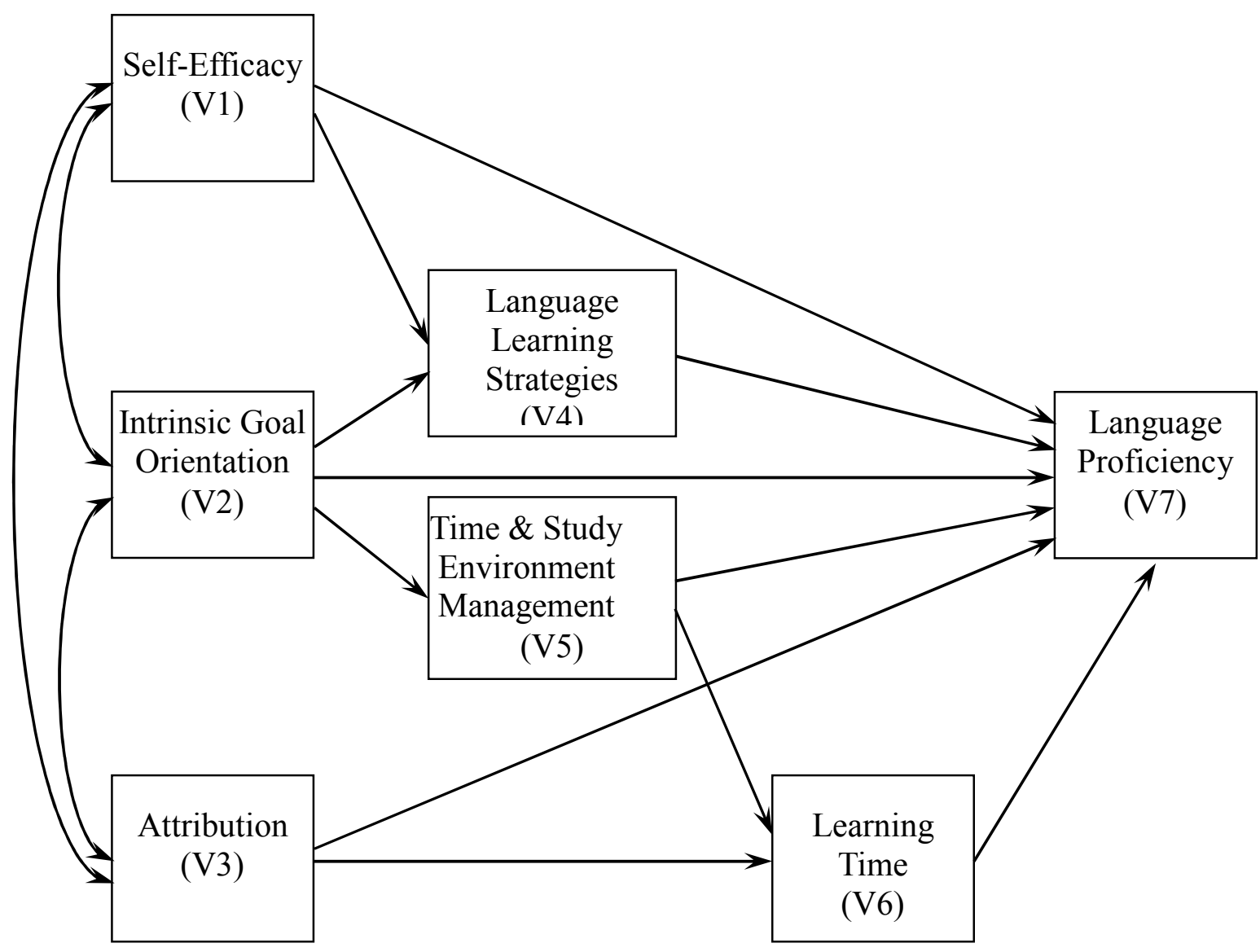

Figure 2. Initial model of self-regulated language learning.

Assessments of model fit were based on multiple criteria including tests and interpretations of individual parameters as well as overall model fit indices. Crowley and Fan (1997) suggested researchers to report a variety of indices because different indices reflect a different aspect of model fit. The Chi-square Likelihood Ratio Statistic ( $\chi 2)$, Goodness of Fit Index (GFI), the Comparative Fit Index (CFI), the Standard Root Mean Square Residual (SRMR), and the Root Mean Square Error of Approximation (RMSEA) were used to assess global fit. GFI ranges from 0 to 1 with larger samples increasing its value. According to Hu \& Bentler (1999), a GFI value above .90 indicates a good fit to the data, values ranging between .08 
and .09 indicate it needs to be adjusted, which takes into account the number of parameters being estimated. The CFI ranges range between 0.0 and 1.0 with values closer to 1.0 indicating good fit. $\mathrm{Hu} \&$ Bentler (1999) suggested that a value above .95 is recognized as indicative of good fit. Values for the SRMR range from zero to 1.0 with well fitting models obtaining values less than .05 (Byrne, 1998; Diamantopoulos and Siguaw, 2000). The RMSEA with 90\% confidence intervals was also used in this study. A cut-off value close to .06 (Hu and Bentler, 1999) or a stringent upper limit of .07 (Steiger, 2007) shows a good fit.

Repeated measures ANOVA. A quasi-experimental pre-post control design was implemented. The comparison for the pre, mid and post measurements for experimental and control groups were used to study the effect of whole intervention. Repeated measures of ANOVA were used to examine the impact of the intervention on students' self-regulation and L2 proficiency. The independent variable in the study is L2 proficiency. The dependent variables include intrinsic goal orientation, self-efficacy, time and study environment management, language learning strategy, and attribution. For each dependent variable, I performed analyses of variances with the group as the independent variable and pre, mid and post measurement as the repeated measurement factor (time) with three levels (pre-, mid- and post-measurement). 


\section{CHAPTER 4}

\section{Results}

In line with the order of my hypotheses, first the correlations regarding the relationships among the variables of the self-regulation model, the model path coefficients, and the model fit consistent with the data are reported. Next, the test of treatment effects using pre, mid and post measurements for the control and the experimental group are reported.

\section{Relationship among the Variables of Self-Regulation Model}

The means and standard deviations for each of the variables in the causal model are presented in Table 3. Pearson correlational analyses were performed to examine associations among the variables. Path analyses were conducted to assess empirically the fit for the proposed latent structure model base on self-regulation theory. The exogenous variables in this study include self-efficacy, intrinsic goal orientation, attribution. The endogenous variables are time and study environment management, language learning strategy, learning time, and L2 proficiency.

Of particular interest among the correlations is that between L2 proficiency as reflected in the College English Test (CET) score and other variables. The intercorrelations among the variables are provided in Table 4. Time and study environment management had strongest correlation with L2 proficiency $(r=.649)$. Learning time $(r=.547)$ and $\operatorname{self-efficacy}(r=.184)$ also correlated significantly with L2 proficiency. Other variables (intrinsic goal orientation, attribution and language learning strategy) did not significantly correlate with students' L2 proficiencies. Students' self-efficacy correlated significantly with all variables except time and study environment management. Their intrinsic goal orientations were significantly related to perceived self-efficacy for academic achievement, language learning strategies, attribution, and 
time and study environment management. Besides self-efficacy and intrinsic goal orientations, students' attributions were positively related to learning time. Time management was correlated with their intrinsic goal orientations, learning time and L2 proficiency. Learning strategies were correlated with self-efficacy and intrinsic goal orientations. Besides L2 proficiency, students' learning time also correlated with self-efficacy, attribution, and time and study environment management.

Table 3

Means and Standard Deviations of Measured Variables $(n=120)$

\begin{tabular}{lcc}
\hline & $M$ & $S D$ \\
\hline Self-efficacy & 38.092 & 7.733 \\
Intrinsic goal orientation & 20.383 & 3.584 \\
Attribution & 20.733 & 4.068 \\
Time and study environment management & 27.292 & 5.155 \\
Language learning strategies & 85.733 & 12.992 \\
Learning time & 23.050 & 6.263 \\
L2 Proficiency & 21.975 & 5.359 \\
\hline
\end{tabular}


Table 4

Correlations among Measured Variables $(n=120)$

\begin{tabular}{|c|c|c|c|c|c|c|}
\hline & 1 & 2 & 3 & 4 & 5 & 6 \\
\hline 1.Self-efficacy & 1 & & & & & \\
\hline 2.Intrinsic goal orientation & $.474^{* *}$ & & & & & \\
\hline 3.Attribution & $.223^{*}$ & $.383^{* *}$ & & & & \\
\hline $\begin{array}{l}\text { 4.Time and study environment } \\
\text { management }\end{array}$ & .177 & $.214^{*}$ & .038 & & & \\
\hline 5.Language learning strategies & $.498^{* *}$ & $.453^{* *}$ & .106 & .173 & & \\
\hline 6.Learning time & $.223^{*}$ & .093 & $.238^{* *}$ & $.529^{* *}$ & .049 & \\
\hline 7.L2 proficiency & $.184^{*}$ & .009 & -.003 & $.649^{* *}$ & .019 & $.547^{* *}$ \\
\hline
\end{tabular}

Note. ${ }^{*} p<.05 ; * * p<.01$

Reported are values of selected fit statistics calculated by EQS (see Figure 3). The proposed model was a good fit of the data. The $90 \%$ confidence interval based on the RMSEA is reported in parentheses: $\chi^{2}(7)=10.184, p=.178 \mathrm{RMSEA}=.062(.000, .138) . \mathrm{GFI}=.976, \mathrm{CFI}=.986$, $\mathrm{SRMR}=.045$. The path coefficients among the seven variables were significant at the .01 level, except for three paths: intrinsic goal orientation and L2 proficiency, attribution and L2 proficiency, language learning strategy and L2 proficiency. 


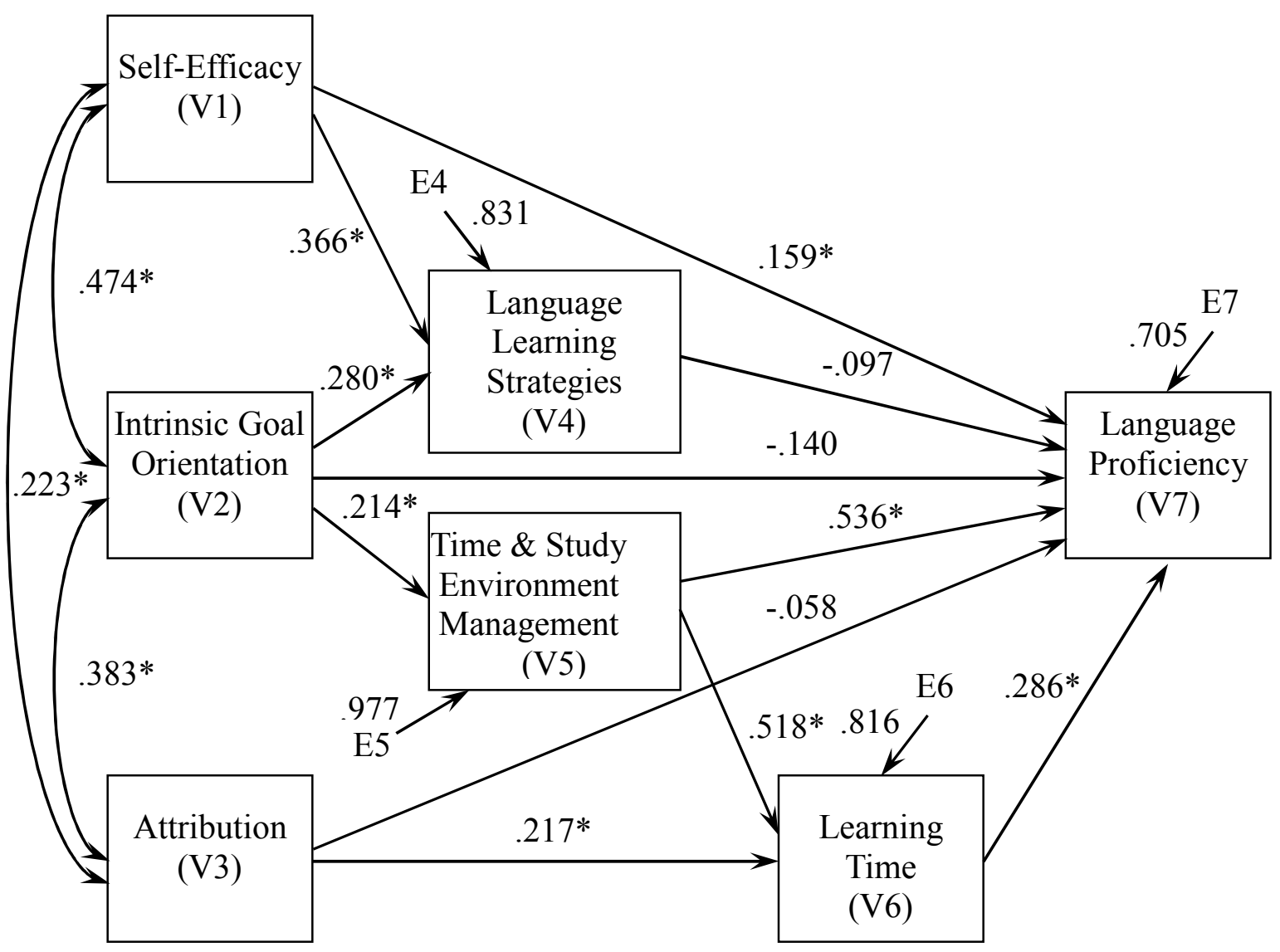

Figure 3. Full path model tested with standardized path coefficients. ${ }^{*} p<.05$.

\section{Effectiveness of the Intervention}

Using data raised with the questionnaires and L2 proficiency tests, the effectiveness of the intervention was examined. This involved computing an analysis of variance in repeated measurements, using group membership (treatment vs. control group) as the independent variable. A series of 2 (condition: treatment vs. control group) $\times 3$ (time: pretest, midtest, and posttest) repeated measures ANOVAs was used to assess the effectiveness of the intervention. For all analysis, the condition was a between-subjects factor, and time was a within-subjects factor. In this study, the evaluation of the effectiveness of the intervention included multiple 
outcome variables, which could be grouped into three categories: students' motivational beliefs, students' strategy use, and students' academic performance.

Students' motivational beliefs. Repeated measures ANOVA procedures were used to assess changes by treatment in the selected motivation variables separately. The variables include intrinsic goal orientation, attribution, and self-efficacy. The means and standard deviations for these three variables are contained in Table 5. Significant interaction between condition and time was found for intrinsic goal orientation and self-efficacy. For attribution, significant main effect of time and main effect of treatment were confirmed.

Table 5

Means and Standard Deviations of Motivational Beliefs

\begin{tabular}{|c|c|c|c|c|c|c|c|}
\hline \multirow{2}{*}{$\begin{array}{l}\text { Strategy } \\
\text { category }\end{array}$} & \multirow[t]{2}{*}{ Time } & \multicolumn{2}{|c|}{$\begin{array}{l}\text { Control group } \\
\qquad n=60\end{array}$} & \multicolumn{2}{|c|}{$\begin{array}{l}\text { Treatment group } \\
\qquad n=60\end{array}$} & \multicolumn{2}{|c|}{$\begin{array}{c}\text { Total } \\
n=120\end{array}$} \\
\hline & & $M$ & $S D$ & $M$ & $S D$ & $M$ & $S D$ \\
\hline \multirow{3}{*}{$\begin{array}{l}\text { Intrinsic goal } \\
\text { orientation }\end{array}$} & Time 1 & 20.500 & 3.596 & 20.267 & 3.598 & 20.383 & 3.584 \\
\hline & Time 2 & 20.300 & 4.264 & 20.867 & 3.496 & 20.583 & 3.893 \\
\hline & Time 3 & 19.200 & 4.157 & 20.900 & 3.672 & 20.050 & 3.998 \\
\hline \multirow[t]{3}{*}{ Attribution } & Time 1 & 20.367 & 3.687 & 21.100 & 4.418 & 20.733 & 4.068 \\
\hline & Time 2 & 19.567 & 3.586 & 20.517 & 3.648 & 20.042 & 3.633 \\
\hline & Time 3 & 18.717 & 3.589 & 20.500 & 3.708 & 19.608 & 3.742 \\
\hline \multirow[t]{3}{*}{ Self-efficacy } & Time 1 & 38.183 & 8.169 & 38.000 & 7.339 & 38.092 & 7.733 \\
\hline & Time 2 & 38.700 & 7.922 & 38.283 & 6.735 & 38.492 & 7.324 \\
\hline & Time 3 & 37.267 & 8.501 & 40.050 & 7.661 & 38.658 & 8.178 \\
\hline
\end{tabular}

Intrinsic goal orientation. With respect to intrinsic goal orientation, a significant Time $\times$ Treatment effect was found, Wilks' Lambda $=.927, F(2,117)=4.583, p=.012$, multivariate 
partial $\eta^{2}=.073$ (see Figure 4). Because the interaction between treatment and time was significant, I chose to ignore the main effects and instead examined the simple effects. To evaluate the simple effects for treatments which are the differences between treatment and control group over three times separately, the alpha level was set at $.0167(.05 / 3=.0167)$ by using Bonferroni approach to control Type 1 error across the three simple effects. Post hoc contrasts revealed a significant difference between treatment group and control group for time point $3, F(1,118)=5.637, p=.016$. I also examined the simple effects for time, that is, the differences in means among three times for control group and differences in means among three times for treatment group. Similarly, to control Type 1 error across the two simple effects for Time, the alpha level was set at $.025(.05 / 2=.025)$. For treatment group, although means of intrinsic goal orientation increased over time, no significant difference was found, Wilks' Lambda $=.948, F(2,58)=1.600, p=.211$. However, significant differences among three times were found for control group, Wilks' Lambda $=.856, F(2,58)=4.869, p=.011$. Follow-up tests were conducted to evaluate the three pairwise differences among the means, with alpha set at .008 to control Type 1 error over three pairwise comparisons. For the control group, there were significant decreases between the means in time 1 and time 3. 


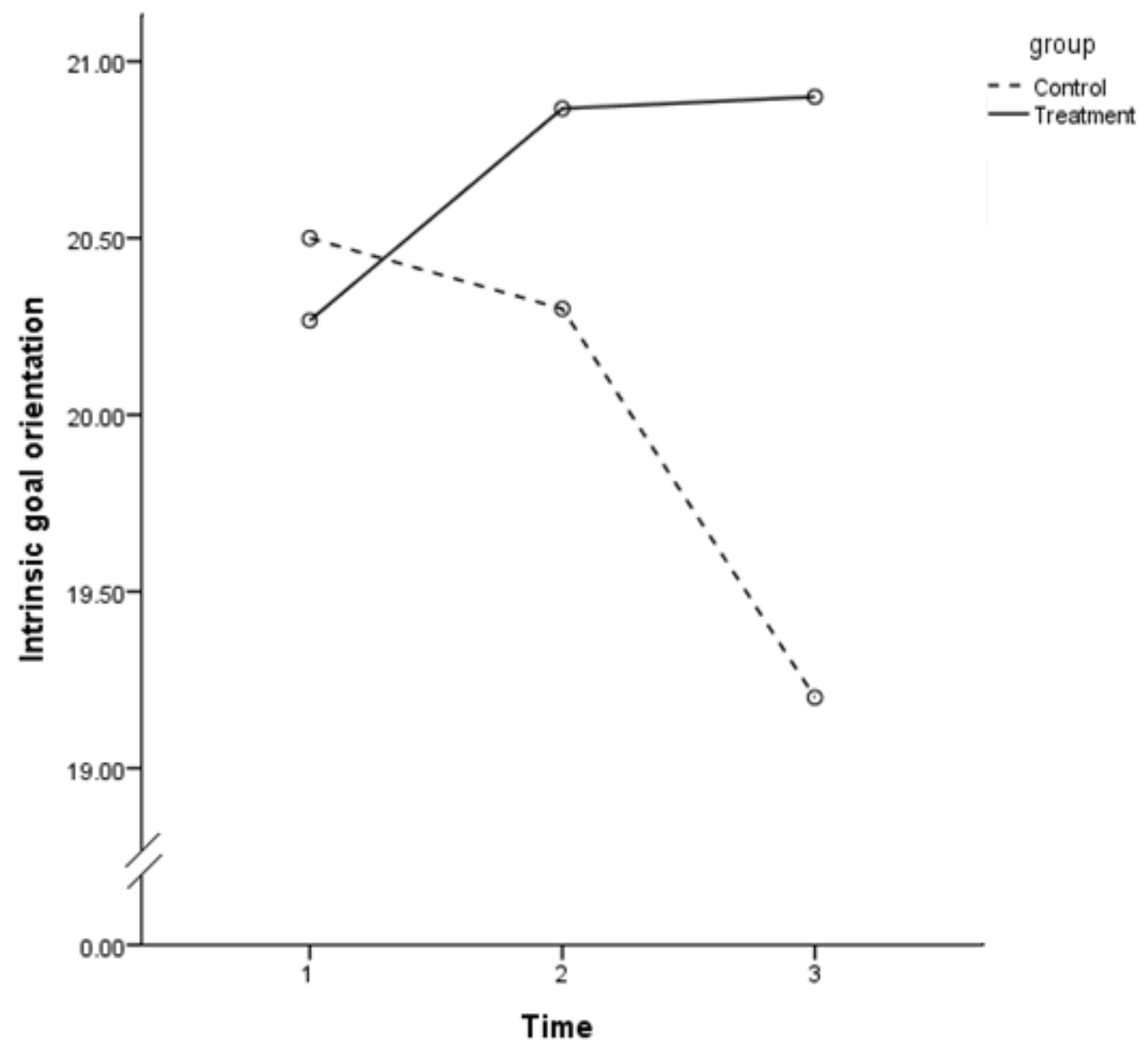

Figure 4. Significant time $\times$ treatment interaction obtained in the analysis of the intrinsic goal orientation data.

Attribution. For attribution, the result revealed a significant main effect of time, Wilks' Lambda $=.934, F(2,117)=4.148, p=.018$, multivariate partial $\eta^{2}=.066$. The main effect of time indicated that attribution of all participants decreased over time. There was a significant main effect of treatment, $F(1,118)=4.382, p=.038$, partial $\eta^{2}=.036$, but no significant interaction between time and treatment, Wilks' Lambda $=.980, F(2,117)=1.181, p=.311$, multivariate partial $\eta^{2}=.020$ (see Figure 5). 


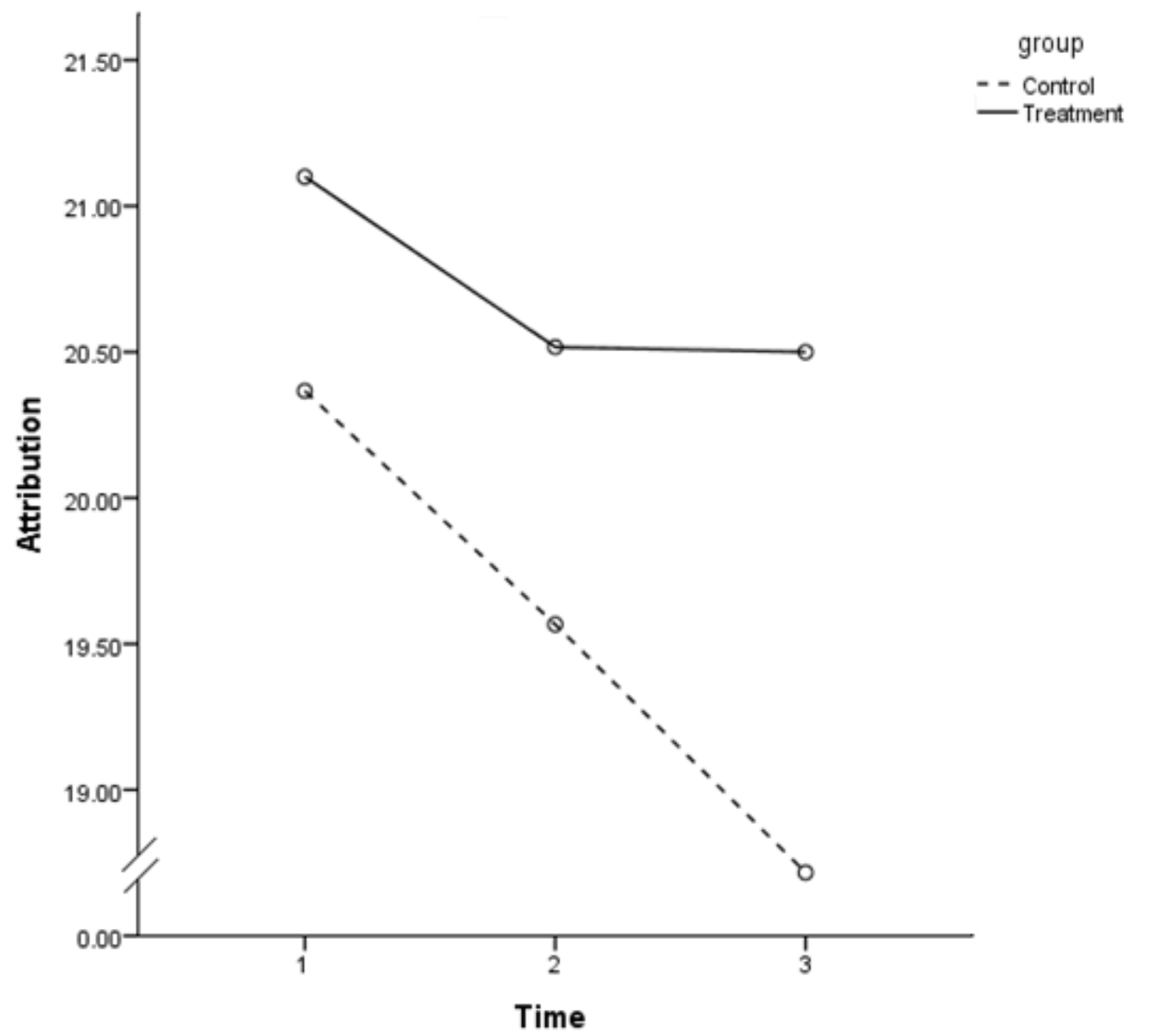

Figure 5. Significant main effect of treatment obtained in the analysis of the attribution data.

Self-efficacy. With respect to self-efficacy, a significant time $\times$ treatment effect was

found, Wilks' Lambda $=.928, F(2,117)=4.561, p=.012$, multivariate partial $\eta^{2}=.072$ (see

Figure 6). For the treatment simple effect, no significant difference was found between treatment group and control group for three time points. Post hoc contrasts revealed no significant simple effects for time for both treatment group, Wilks' Lambda $=.913, F(2,58)=$ $2.750, p=.072$, multivariate partial $\eta^{2}=.087$; and control group, Wilks' Lambda $=.926, F(2,58)$ $=2.321, p=.107$, multivariate partial $\eta^{2}=.074$. 


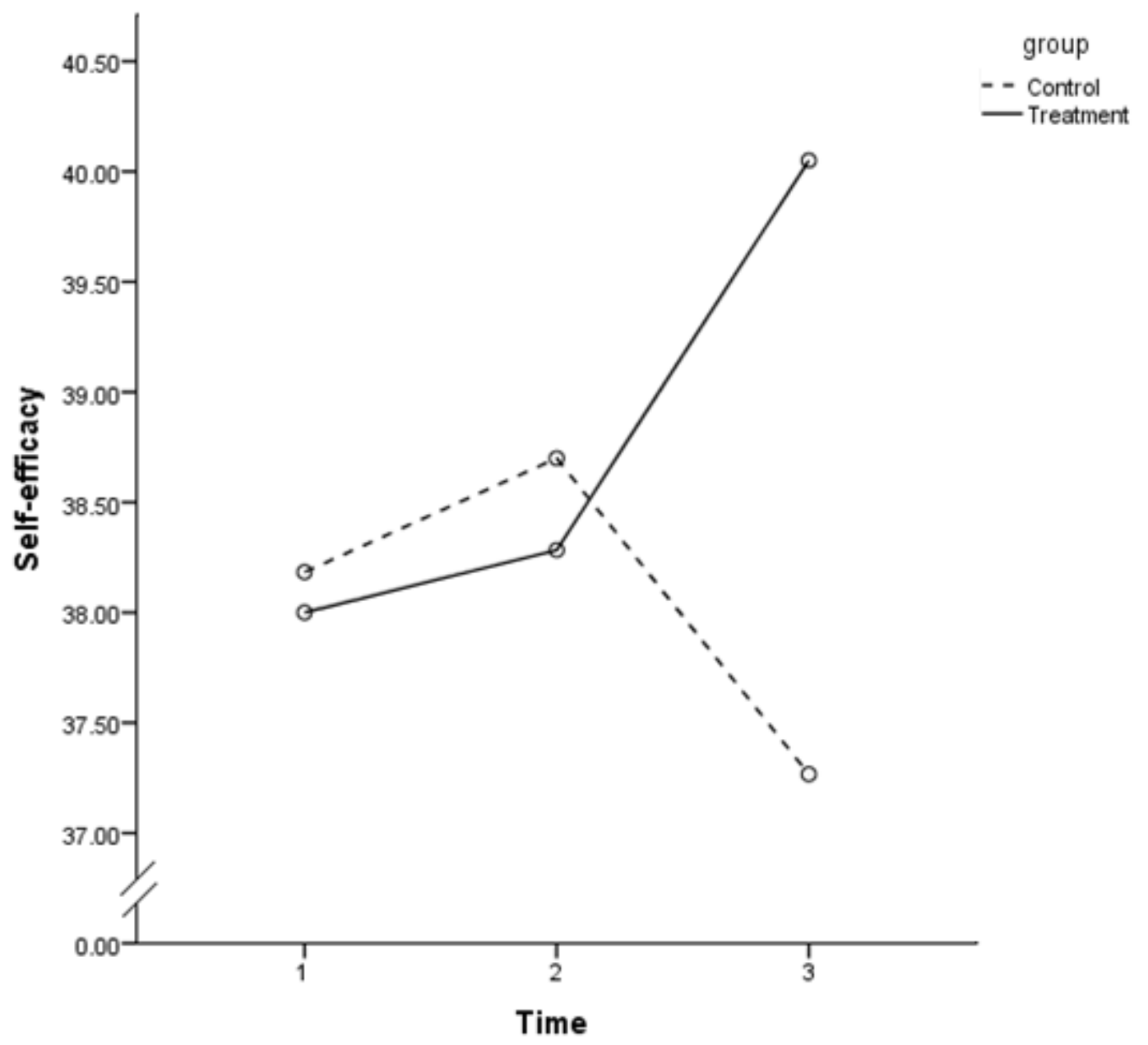

Figure 6. Significant time $\times$ treatment interaction obtained in the analysis of the self-efficacy data.

Students' strategy use. There are two categories of strategy measured in the study: time and study environment management skills, and language learning strategies.

Time and study environment management. With respect to time and study environment management, a significant main effect of time, Wilks' Lambda $=.699, F(2,117)=25.140, p$ $<.01$, multivariate partial $\eta^{2}=.301$, and a significant time $\times$ treatment effect, Wilks' Lambda $=.686, F(2,117)=26.739, p<.01$, multivariate partial $\eta^{2}=.314$ were found (see Figure 7). Significant differences among three times were found for both control group, Wilks' Lambda $=.892, F(2,58)=3.506, p=.037$; and treatment group, Wilks' Lambda $=.479, F(2,58)=$ 
$31.519, p<.001$. For control group, there were significant decreases between the means in time 1 and time 2. For treatment group, there were significant increases between the means in time 2 and time 3 , and also time 1 and time 3 .

Table 6

Means and Standard Deviations of Time and Study Environment Management

\begin{tabular}{|c|c|c|c|c|c|c|}
\hline \multirow{2}{*}{ Time } & \multicolumn{2}{|c|}{$\begin{array}{l}\text { Control group } \\
\qquad n=60\end{array}$} & \multicolumn{2}{|c|}{$\begin{array}{l}\text { Treatment group } \\
\qquad n=60\end{array}$} & \multicolumn{2}{|c|}{$\begin{array}{c}\text { Total } \\
n=120\end{array}$} \\
\hline & $M$ & $S D$ & $M$ & $S D$ & $M$ & $S D$ \\
\hline Time 1 & 27.850 & 5.191 & 26.733 & 5.102 & 27.292 & 5.155 \\
\hline Time 2 & 27.100 & 5.268 & 27.283 & 5.221 & 27.192 & 5.223 \\
\hline Time 3 & 27.517 & 5.429 & 29.683 & 6.111 & 28.600 & 5.857 \\
\hline
\end{tabular}




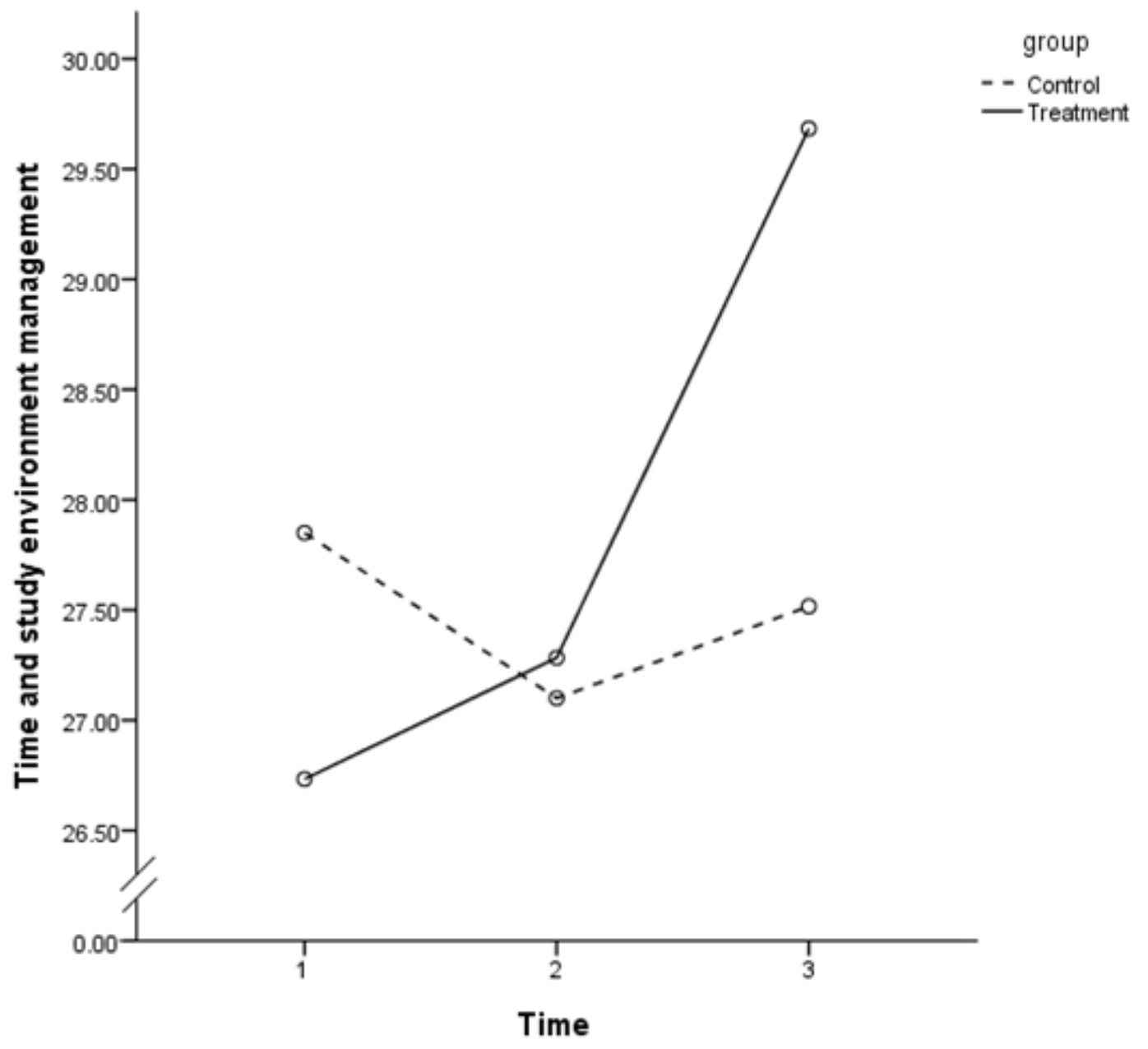

Figure 7. Significant time $\times$ treatment interaction obtained in the analysis of the time and study environment management data.

Language learning strategy. Participants' language learning strategy use was examined by overall score and subscale scores respectively. Firstly, repeated measures analysis of variance procedures were used to test differences by treatment in overall language learning strategy use over time. The means and standard deviations for the overall learning strategies scores are presented in Table 7.

A 2 (treatment / control) $\times 3$ (assessment times) analysis revealed a significant main effect of time, Wilks' Lambda $=.715, F(2,117)=23.295, p<.01$, multivariate partial $\eta^{2}=.285$. 
There was no significant main effect of treatment or significant interaction between time and treatment (see Figure 8). Follow-up polynomial contrasts indicated a significant linear effect with means of learning strategy use frequencies increasing over time, $F(1,118)=45.979, p<.01$, partial $\eta^{2}=.280$.

Table 7

Means and Standard Deviations of Overall Language Learning Strategy

\begin{tabular}{|c|c|c|c|c|c|c|}
\hline \multirow[t]{2}{*}{ Time } & \multicolumn{2}{|c|}{$\begin{array}{l}\text { Control group } \\
\qquad n=60\end{array}$} & \multicolumn{2}{|c|}{$\begin{array}{l}\text { Treatment group } \\
\qquad n=60\end{array}$} & \multicolumn{2}{|c|}{$\begin{array}{c}\text { Total } \\
n=120\end{array}$} \\
\hline & $M$ & $S D$ & $M$ & $S D$ & $M$ & $S D$ \\
\hline Time 1 & 85.033 & 14.172 & 86.433 & 11.774 & 85.733 & 12.992 \\
\hline Time 2 & 90.367 & 14.847 & 91.017 & 12.584 & 90.692 & 13.708 \\
\hline Time 3 & 91.850 & 15.343 & 95.917 & 12.520 & 93.883 & 14.093 \\
\hline
\end{tabular}




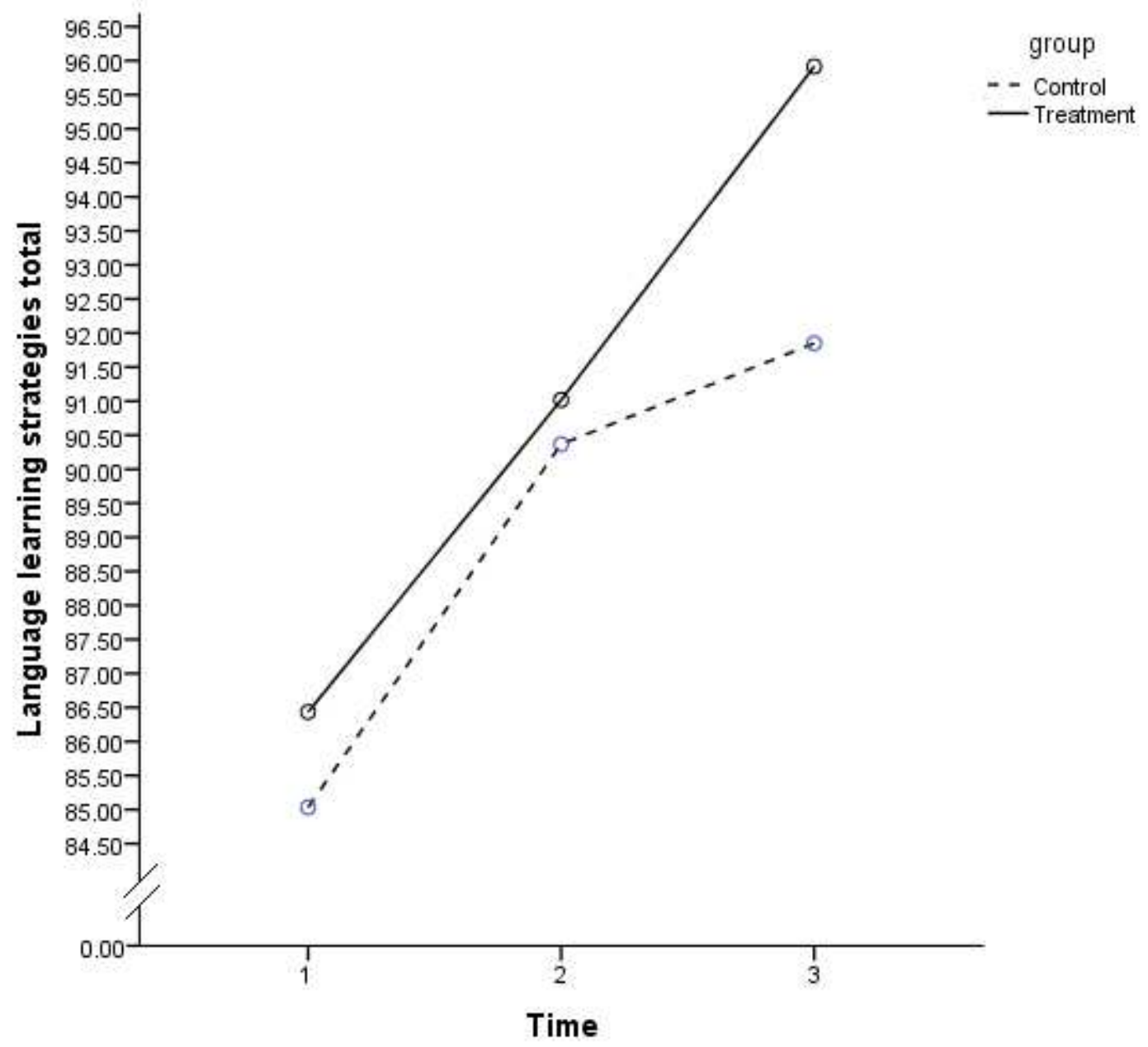

Figure 8. Significant main effect of time obtained in the analysis of the overall language learning strategy data.

A series of $2 \times 3$ repeated measures ANOVAs was used to assess changes by treatment in six categories of learning strategies separately. The means and standard deviations for the six categories of learning strategies are presented in Table 8.

The main effect of time indicated that all categories of learning strategy use frequency increased over time. Neither the main effects of treatment nor interaction effects of cognitive strategies, affective strategies and social strategies was significant. 
Table 8

Means and Standard Deviations of Six Categories of Language Learning Strategy

\begin{tabular}{|c|c|c|c|c|c|c|c|}
\hline \multirow{2}{*}{$\begin{array}{l}\text { Strategy } \\
\text { category }\end{array}$} & \multirow{2}{*}{ Time } & \multicolumn{2}{|c|}{$\begin{array}{l}\text { Control group } \\
\qquad n=60\end{array}$} & \multicolumn{2}{|c|}{$\begin{array}{l}\text { Treatment group } \\
\qquad n=60\end{array}$} & \multicolumn{2}{|c|}{$\begin{array}{c}\text { Total } \\
n=120\end{array}$} \\
\hline & & $M$ & $S D$ & $M$ & $S D$ & $M$ & $S D$ \\
\hline \multirow[t]{3}{*}{ Memory } & Time 1 & 19.250 & 4.233 & 19.967 & 3.746 & 19.608 & 3.996 \\
\hline & Time 2 & 21.733 & 4.562 & 21.467 & 4.292 & 21.600 & 4.123 \\
\hline & Time 3 & 21.600 & 4.412 & 23.250 & 4.099 & 22.425 & 4.287 \\
\hline \multirow[t]{3}{*}{ Cognitive } & Time 1 & 15.083 & 3.562 & 14.650 & 3.419 & 14.867 & 3.483 \\
\hline & Time 2 & 15.500 & 3.587 & 15.467 & 3.457 & 15.483 & 3.507 \\
\hline & Time 3 & 16.050 & 3.249 & 16.767 & 3.186 & 16.408 & 3.224 \\
\hline \multirow{3}{*}{$\begin{array}{l}\text { Compensa } \\
\text { tion }\end{array}$} & Time 1 & 16.200 & 3.241 & 17.000 & 3.334 & 16.600 & 3.299 \\
\hline & Time 2 & 16.417 & 3.038 & 17.533 & 3.296 & 16.975 & 3.206 \\
\hline & Time 3 & 17.217 & 3.163 & 18.283 & 2.744 & 17.750 & 2.997 \\
\hline \multirow{3}{*}{$\begin{array}{l}\text { Metacogni } \\
\text { tive }\end{array}$} & Time 1 & 13.350 & 2.667 & 13.700 & 2.669 & 13.525 & 2.663 \\
\hline & Time 2 & 13.867 & 2.709 & 14.483 & 2.205 & 14.175 & 2.479 \\
\hline & Time 3 & 14.083 & 2.836 & 15.600 & 2.149 & 14.842 & 2.619 \\
\hline \multirow[t]{3}{*}{ Effective } & Time 1 & 8.917 & 2.085 & 8.667 & 1.847 & 8.792 & 1.966 \\
\hline & Time 2 & 9.633 & 1.974 & 9.300 & 1.985 & 9.467 & 1.979 \\
\hline & Time 3 & 9.533 & 2.045 & 9.383 & 1.958 & 9.458 & 1.995 \\
\hline \multirow[t]{3}{*}{ Social } & Time 1 & 12.233 & 2.982 & 12.450 & 2.855 & 12.342 & 2.909 \\
\hline & Time 2 & 13.217 & 3.026 & 12.767 & 2.739 & 12.992 & 2.883 \\
\hline & Time 3 & 13.367 & 2.899 & 13.633 & 2.262 & 13.500 & 2.592 \\
\hline
\end{tabular}


With respect to memory strategies, a significant time $\times$ treatment effect was found, Wilks' Lambda $=.929, F(2,117)=4.443, p=.013$, multivariate partial $\eta^{2}=.071$ (see Figure 9). Post hoc contrasts revealed significant time simple effects. There were significant differences among the three times for both control group, Wilks' Lambda $=.820, F(2,58)=6.369, p=.003$, and treatment group, Wilks' Lambda $=.634, F(2,58)=15.887, p<.001$. Follow-up tests were conducted to evaluate the three pairwise differences among the means, with alpha set at .008 to control Type 1 error over three pairwise comparisons. For the control group, there were significant increases between the memory strategy use in time 1 and time 2 , time 1 and time 3 , but no significant change between time 2 and time 3 . For treatment group memory strategy use frequency significantly increased over three times. 


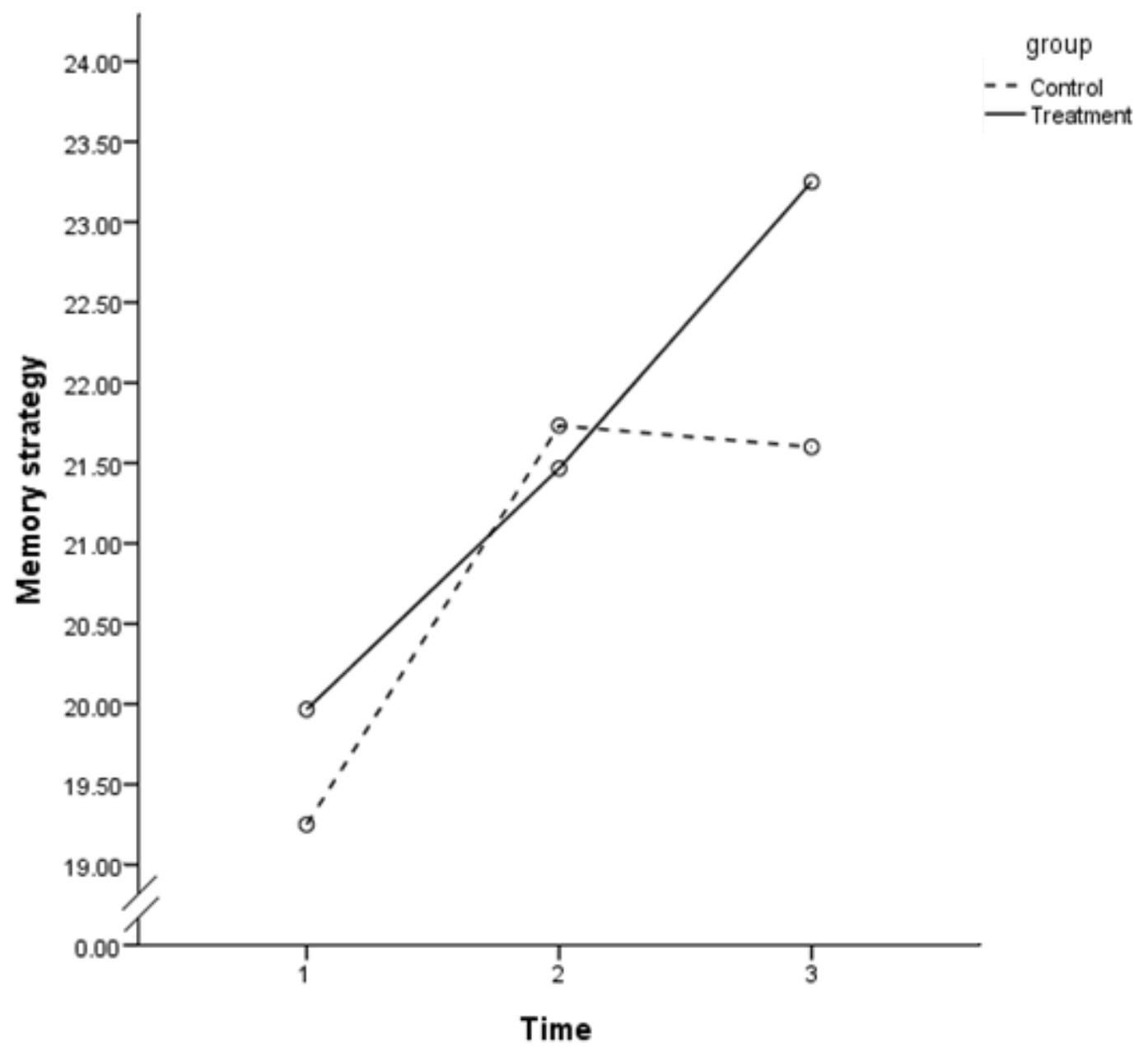

Figure 9. Significant time $\times$ treatment interaction obtained in the analysis of the memory strategy data.

With respect to compensation strategies, a significant main effect of treatment was found, $F(1,118)=4.591, p=.034$, partial $\eta^{2}=.037($ see Figure 10$)$. 


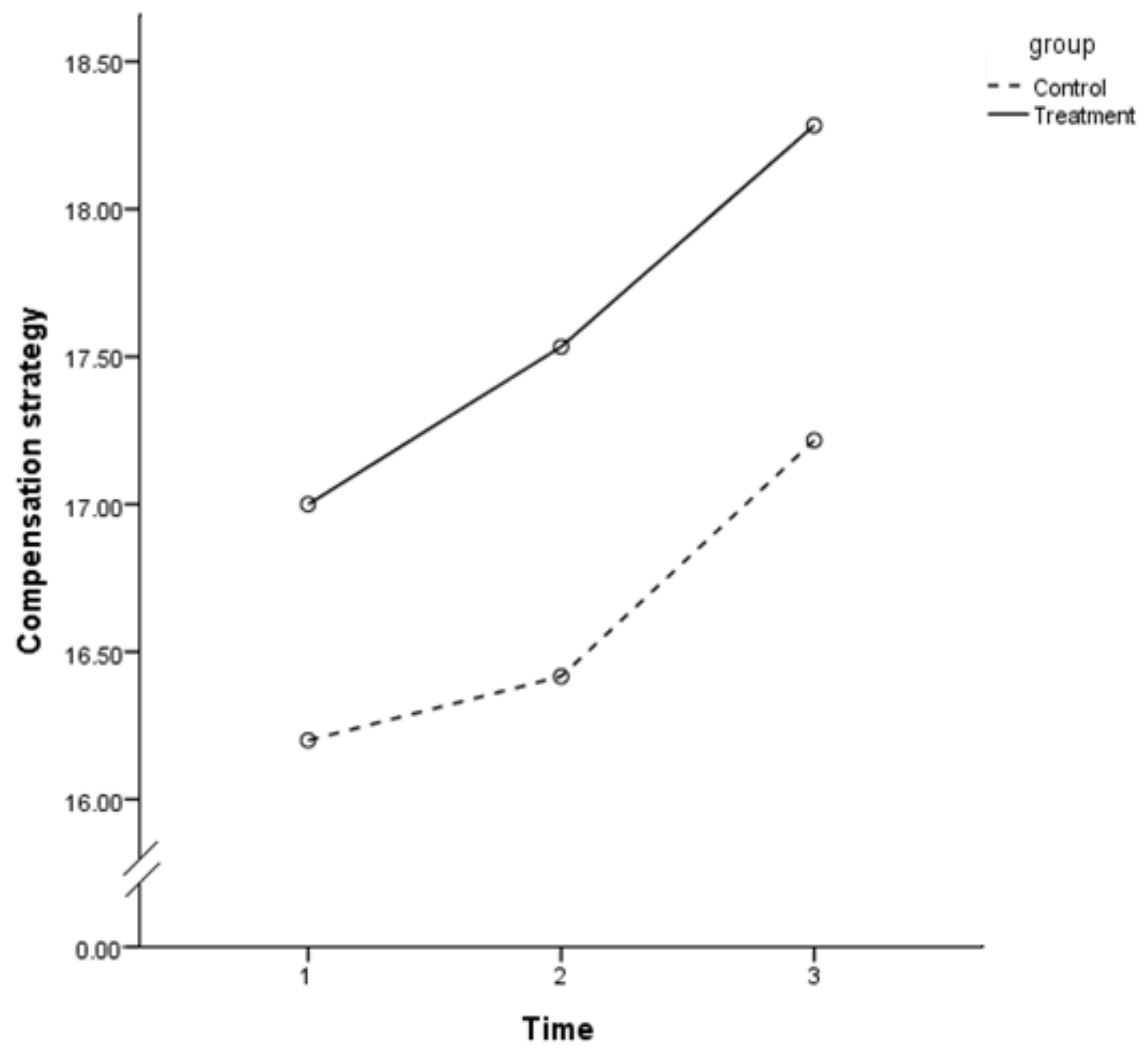

Figure 10. Significant main effect of treatment obtained in the analysis of the compensation strategy data.

With respect to metacognitive strategies, a significant main effect of treatment, $F(1,118)$ $=4.961, p=.005$, partial $\eta^{2}=.040$, and a significant time $\times$ treatment effect were found, Wilks' Lambda $=.939, F(2,117)=3.799, p=.025$, multivariate partial $\eta^{2}=.061($ see Figure 11$)$. Post hoc contrasts revealed a significant difference between treatment group and control group for time point $3, F(1,118)=10.901, p=.001$. I also examined the time simple main effects. There was no significant difference among three times for control group, Wilks' Lambda $=.924, F(2$, $58)=2.374, p=.102$. However, there were significant differences among three times for 
treatment group, Wilks' Lambda $=.618, F(2,58)=17.942, p<.001$. Follow-up tests were conducted to evaluate the three pairwise differences among the means, with alpha set at .008 to control Type 1 error over three pairwise comparisons. For the treatment group, there were significant increases between the metacognitive strategy use in time 1 and time 3 , time 2 and time 3 , but no significant change between time 1 and time 2 .

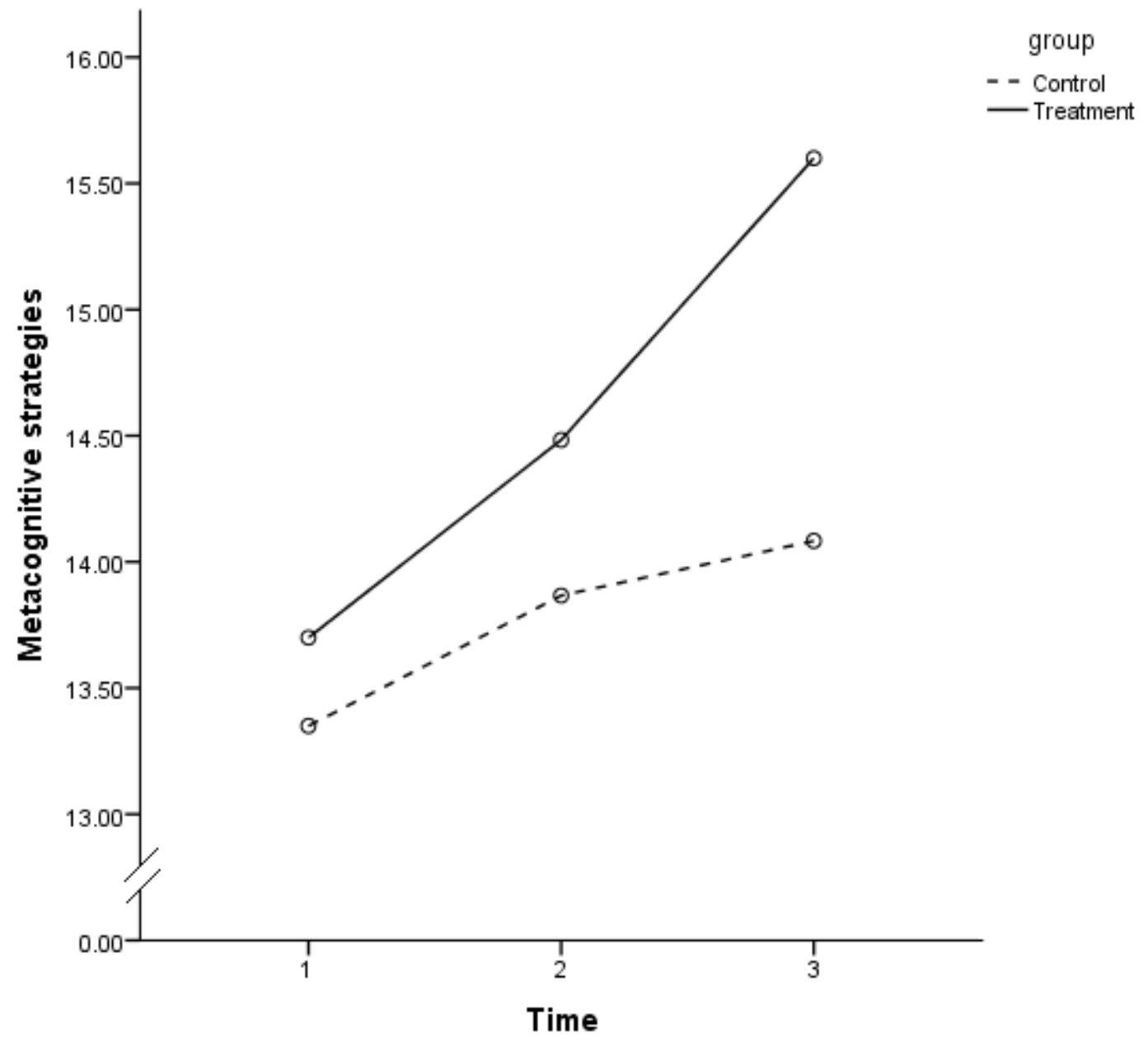

Figure 11. Significant time $\times$ treatment interaction obtained in the analysis of the metacognitive strategy data. 
L2 proficiency. Repeated measures ANOVA procedures were used to test differences by treatment in L2 proficiency over time. The means and standard deviations for the L2 proficiency test scores are presented in Table 9.

A 2 (treatment/ control) $\times 3$ (assessment times) analysis revealed a significant main effect of time, Wilks' Lambda $=.634, F(2,117)=33.727, p<.001$, multivariate partial $\eta^{2}=.366$ and a significant main effect for treatment, $F(1,118)=8.342, p=.005$, partial $\eta^{2}=.066$. There was also a significant time $\times$ treatment effect, Wilks' Lambda $=.808, F(2,117)=13.887, p<.01$, partial $\eta^{2}=.192$ (see Figure 12).

Because the interaction between treatment and time was significant, I chose to ignore the main effects and instead examined the simple effects. To evaluate the simple effects for treatments, the alpha level was set at $.0167(.05 / 3=.0167)$ by using Bonferroni approach to control Type 1 error across the three simple effects. There were no significant difference between treatment group and control group at time $1, F(1,118)=.195, p=.660$ and at time $2, F$ $(1,118)=5.260, p=.024$, but there was significant difference between treatment group at time 3 , $F(1,118)=31.057, p<.001$. I also examined the simple effects for time, and to control Type 1 error across the two simple effects for time, the alpha level was set at $.025(.05 / 2=.025)$. There was no significant difference among three times for control group, Wilks' Lambda $=.917, F(2$, $58)=2.610, p=.082$, but a significant difference among three times for treatment group, Wilks' Lambda $=.424, F(2,58)=39.386, p<.001$. Follow-up tests were conducted to evaluate the three pairwise differences among the means for treatment group, with alpha set at $.008(.25 / 3$ $=.008)$ to control Type 1 error over three pairwise comparisons. The L2 proficiency significantly improved over time for the treatment group. There were significant increases between the L2 proficiency in time 1 and time 2 , time 2 and time 3 , as well as time 1 and time $3, p<.001$. 
Table 9

Means and Standard Deviations of L2 Proficiency

\begin{tabular}{lcccccc}
\hline & \multicolumn{2}{c}{$\begin{array}{c}\text { Control group } \\
\text { Time }\end{array}$} & \multicolumn{2}{c}{$\begin{array}{c}\text { Treatment group } \\
n=60\end{array}$} & \multicolumn{2}{c}{$\begin{array}{c}\text { Total } \\
n=120\end{array}$} \\
\cline { 2 - 7 } & $M$ & $S D$ & $M$ & $S D$ & $M$ & $S D$ \\
\hline Time 1 & 22.192 & 5.064 & 21.758 & 5.673 & 21.975 & 5.359 \\
Time 2 & 22.392 & 5.174 & 24.333 & 4.029 & 23.362 & 4.719 \\
Time 3 & 23.542 & 5.214 & 28.208 & 3.859 & 25.875 & 5.133 \\
\hline
\end{tabular}




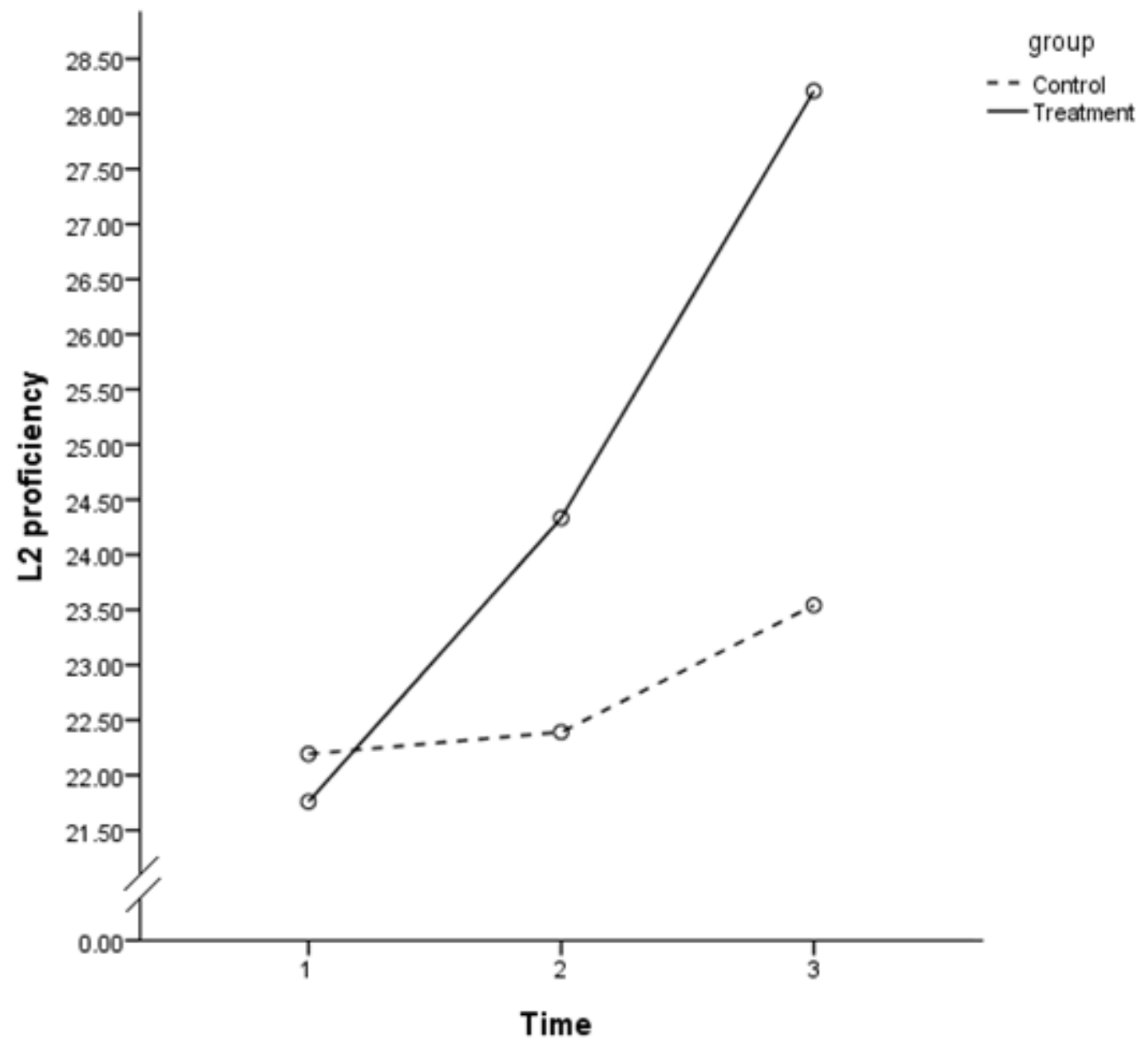

Figure 12. Significant time $\times$ treatment interaction obtained in the analysis of the L2 proficiency data. 


\section{CHAPTER 5}

\section{Discussion}

This chapter will discuss the implications of the results presented in Chapter 4. First, the findings of the main and supplemental analyses are discussed in reference to the possible explanations of the findings and their convergence or divergence with previous literature. Next theoretical and research implications of the study are discussed. Finally limitations of the study are reviewed and suggestions for future directions with self-regulated learning in the field of L2 research are provided.

\section{Summary of Findings}

Self-regulation model in the context of L2 learning. Hypothesis 1 stated that there would be causal influences of self-regulated learning variables across three phases (forethought, performance, and reflection phase) in the context of L2 learning. The feedback from the prior phase impacts the adjustments regarding current and subsequent efforts in the self-regulatory process. Furthermore, student self-regulation influences their L2 proficiency via the enhancement of motivational variables. This hypothesis was supported by the results.

As anticipated, self-efficacy and goal orientation, which are two key self-motivational beliefs in the forethought phase were active throughout the model. Firstly, there was significant correlation between students' self-efficacy and intrinsic goal orientation, which is in accord with Zimmerman (2000), who assumed significant correlations among variables within a particular self-regulated phase. Secondly, these two forethought variables influenced the subsequent variables in the performance phase. Students' self-efficacy was found to affect their use of language learning strategies, and students' intrinsic goal orientation influenced both time and study environment management skills and language learning strategies. This finding is consistent 
with previous research evidence which shows that students' self-efficacy beliefs and intrinsic goal orientation are closely linked to cognitive strategy use and time management in varied school subjects (Britton \& Tesser, 1991; Grant and Dweck, 2003; Schunk \& Schwartz, 1993; Zimmerman, Bandura, \& Martinez-Pons, 1992). Thirdly, both self-efficacy and intrinsic goal orientation are correlated with attribution, which is a reflection phase variable. The importance of self-efficacy to such critical variables in future learning processes as goal setting, students' choices of activities, efforts, task persistence and positive attribution has been established in prior studies (Bandura, 1986; Schunk, 1995; Zimmerman \& Cleary, 2009; Zimmerman \& Kitsantas, 1997). For example, self-efficacious students were more likely to report use of cognitive strategies and metacognitive strategies and to persist more often at difficult or uninteresting academic tasks than self-doubters (Pajares, 2008). Research evidence also suggests that goal orientation is associated with a wide range of motivational beliefs that are important mediators of self-regulated learning. Generally, an intrinsic goal orientation is related to a positive pattern of attributions and active attitudes toward learning, whereas an extrinsic goal orientation is linked to a maladaptive pattern of attributions and lower motivation (Ames \& Archer, 1988; Pintrich \& Schunk, 1996; Weiner, 1979). Researchers in the field of L2 learning (Oxford \& Nyikos, 1989; Cohen and Weaver, 2005) also found that more motivated learners use a significantly greater range of appropriate strategies than do less motivated learners. Taken together, these findings mirror Zimmerman's process model of self-regulation $(2000,2004)$ and correspond with the findings in previous literature.

The hypothesized model also anticipated the favorable influence of motivational variables on the academic performance. It turned out that in the current study self-efficacy promoted students' L2 proficiencies directly. Intrinsic goal orientation enhanced L2 proficiency 
indirectly through its impact on the learning time and study environment management skills. Attribution benefited L2 proficiency indirectly through its impact on learning time. Clearly the effective use of one's study time is essential to academic success because "insufficient time compels expediency--the very antithesis of self-regulated learning" (Zimmerman, Bonner \& Kovach, 1996). Restructuring one's physical and social environments is another important aspect of self-regulation (Zimmerman \& Martinez-Pons, 1988). In the current study, selecting appropriate environments and controlling the distractions once they occur is one predictor of high L2 proficiency. These findings are consistent with previous literature (Eisenberg, 2010; Graham \& Harris, 2000; Schraw et al., 2006; Whitebread et al., 2009), which support the link between motivation, learning strategies and academic achievement.

However there were several paths that were not significant. Neither intrinsic goal orientation nor attribution was found to affect language proficiency directly. As I discussed above, however, intrinsic goal orientation and attribution benefited L2 proficiency indirectly through its impact on performance phase variables (time \& study environment management skills and language learning strategies). One potential explanation for this finding is that because of the dynamic and fluid nature of motivational variables during the learning process, intrinsic goal orientation and attribution have causal influences on academic performance via the mediators across phases of self-regulated learning processes. Contrary to my expectation, one performance variable, language learning strategy, was not found to account for any significant variance in L2 proficiency. This is inconsistent with most previous research that tends to support that language learning strategy use is beneficial for language learners' language proficiency. It seems that eliminating the path between language learning strategy and L2 proficiency, and adding a path from language learning strategy to time and study environment management skills 
would not improve the model fit. One possible explanation for this finding is I used composite scores of six categories of language learning strategies instead of one particular category of language learning strategies, which might have underrated the influence of one particular category of language learning strategies on L2 proficiency. Most researchers agree that metacognitive learning strategies are vital for language learning because they develop into necessary skills for self-directed learning (Oxford, 1990). Metacognitive strategies for planning, monitoring, and modifying cognition have been reported as the strongest predictors of academic performance in numerous studies (Flavell, 1979; Schraw et al., 2006; Schraw \& Moshman, 1995). Some researchers also found high-proficiency language learners manifested less preference for compensation strategies (e.g. overcoming language limitations), but used them more effectively. Additional model testing with different categories of language learning strategies separately is necessary. An alternative explanation for the nonsignificant path between language learning strategy and L2 proficiency is that frequency of learning strategy use might not be the most crucial determinant of effective use of language learning strategies. Although more proficient language learners use a greater variety and often a greater number of learning strategies (Anderson, 2005; Green \& Oxford, 1995; O’Malley \& Chamot, 1990; Wharton, 2000), they seem to have better understanding of how to employ strategies flexibly by selecting those strategies that are appropriate for performing a particular learning task (Cohen \& Macaro, 2007; Ellis, 1994; Green and Oxford, 1995). Chamot and Rubin (1994) also indicated that "the good language learner cannot be described in terms of a single set of learning strategies but rather through their ability to understand and develop a personal set of effective strategies" ( p. 372). It is suggested that future research explore an alternative model to investigate whether a modified 
model better explains the role of language learning strategies on the enhancement of L2 proficiency.

Effectiveness of the intervention. Hypothesis 2 stated that there would be significant treatment effect of self-regulated learning training for L2 learners. The evaluation of the effectiveness of the intervention included multiple outcome variables, which could be grouped into three categories: students' motivational beliefs, students' strategy use, and students' academic performance. The effectiveness of the intervention on the three categories of variables above has been empirically demonstrated in this study.

With regard to three variables (intrinsic goal orientation, self-efficacy, and attribution) related to students' motivational beliefs, significant interaction between condition and time was found for intrinsic goal orientation and self-efficacy, and significant main treatment effect for attribution was also confirmed. The results indicate significant training effects for all three variables. The performance for intrinsic goal orientation and attribution increased slightly in the treatment group from the first measuring point to the third, and the self-efficacy increased significantly over time, while the control group demonstrated a deduction in motivational levels over time. This general trend of decreasing motivation over time in the group without intervention has been recorded in the literature (Pintrich \& Schunk, 2002). This finding corresponds with results in other studies which confirm the effect of self-regulation training on enhancement and retention of motivational beliefs (Bouffard-Bouchard, 1990; Pajares 1996; Pintrich, 2000; Stoeger \& Ziegler, 2008).

In addition to the favorable effects recorded for motivational beliefs, the treatment group also reported increased learning strategy use. Although performance on time and study environment management skills and all language learning strategies grew for all participants as 
time passed by, the students in the treatment group reported significantly improved time and study environment management skills, and three categories of language learning strategies (memory strategy, compensation strategy and metacognitive strategy) in comparison to the control group. The beneficial training effect on study environment management skills was confirmed in this study. Time and study environment management skills have been included as one of the essential self-regulated learning skills in previous self-regulation training programs. For example, Schmitz and Wiese (2006) conducted four weekly two-hour training sessions of self-regulated learning with a sample of civil engineering students at a German university. In their study, besides several variables of motivation, significant improved time management skills were found in the treatment group as a consequence of the training. In addition, keeping selfregulated diaries may enforce students' metacognition and time management strategies in the present study. These results are supported by the literature on the relationship between metacognition, time management strategies and academic achievement (Chan \& Moore, 2006; Sperling et al., 2004; Zimmerman, 1994).

In spite of significant intervention effects on memory strategy, compensation strategy and metacognitive strategy, the students in the treatment group showed no immediate performance growth in cognitive strategy, effective strategy, and social strategy. A potential explanation for the nonsignificant improvement on particular categories of language learning strategies is the influence of students' cultural values and the context of the learning situation on their acceptability of language learning strategies (Chamot, 2004; Oxford and Burry-Stock, 1995; Wharton, 2000). In order to be successful in finishing competitive tasks, language learners in cultures that focus on individual competition may prefer strategies that allow them to work alone rather than using social strategies such as collaboration with others. Moreover, task requirement 
and teachers' expectations, expressed through classroom instructional and testing methods, strongly shape learners' acceptability of strategies (O’Malley et al., 1985; Chamot, 1987). For example, the students educated in traditionally didactic settings were found to employ more memorization strategies (Politzer, 1983). The participants in the study were educated in the environments of lecture- and textbook-centered teaching approach, which emphasizes grammar learning, error correction, and standardized testing. This learning context might encourage development of learning strategies like memorizing, planning, monitoring, and reasoning rather than learning strategies for developing communicative competence. This finding is in accordance with research evidence which shows that improvement on motivation affects metacognitive strategy use most and affects social strategy use least (Schmidt and Watanabe, 2001). In addition, one of the challenges in teaching "learning to learn" is that changing ineffective learning and study habit is a difficult process. The key to success is practicing the learning strategies so that they become automatic. Due to time limitation, in this study the training session on learning strategies focus more on time and study environment management skills and metacognitive strategies. The participants need more time and practice to internalize the strategies taught during the training sessions.

The study's results show that this intervention is well suited to attain its goal in academic growth. As expected, L2 proficiency scores of all participants increased over time because learners in both the treatment group and the control group were learning English as a Second language in their regular curriculum. Although the baseline L2 proficiency scores for the treatment group and the control group are comparable, the students in the treatment group showed significant growth in their L2 proficiency as a consequence of the intervention, while the performance of the control group remained stable. This finding is particularly meaningful in that 
the available language learning time in class for the treatment group was less than that for the control group. As introduced earlier, while the control group used the regular intensive English course, for the treatment group, a substantial portion of instructional time on class was dedicated to teaching and practicing self-regulated learning skills. Although it may seem that in-class selfregulation training takes valuable time away from teaching the language content, students in the treatment group became more efficient in setting goals; managing time and study environment; planning, monitoring and evaluating their language learning processes. As a result, they took more responsibility for self-directing their learning out of class, and gained more confidence in their ability to learn and use L2, so this should compensate for the outlay of time in training them. I can therefore declare that in the current study self-regulation intervention for L2 learners promoted their L2 proficiency via the enhancement of motivational beliefs and learning strategy use. This finding is consistent with numerous previous self-regulation training research which shows significant effects on students' achievement in various academic disciplines and learning contexts (Cleary \& Zimmerman, 2004; Glaser \& Brunstein, 2007; Sawyer, Graham, \& Harris, 1992; Lee, Lim \& Grabowski, 2010; Matuga, 2009; Perels, Dignath, \& Schmitz, 2009; Souvignier \& Mokhlesgerami, 2006; Winters, Greene \& Costich, 2008).

\section{Theoretical and Research Implications}

The purpose of building a self-regulated learning model in the current study is to identify the components of self-regulated learning that contribute to L2 proficiency. Theoretically, this study extends the current literature by examining relationships among self-regulation variables in the context of L2 learning. Besides language learning strategies, researchers in the field of L2 learning need to take learners' motivational orientations (e.g. self-efficacy, goal orientation, and academic attribution) into consideration. The instructional implication of building this model is 
that by understanding the process of self-regulated learning for L2 learners, language educators will be more familiar with the factors that influence a learner's self-regulation and the strategies they can use to promote self-regulated learning in their classrooms.

The purpose of the intervention program is to improve language learners' L2 proficiency through changing aspects of their motivation and learning strategies. The results of the immediate training effects confirm that academic self-regulation is a trainable student characteristic (Cleary \& Zimmerman, 2004; Schunk, 1996; Zimmerman, 1989) and selfregulation training can be used effectively in a L2 classroom setting. From a pedagogic point of view, this finding has implications for the design of strategy-based instruction intended to foster students' self-regulated learning in the L2 classroom. The process of change begins by encouraging students to observe and reflect on one's learning behavior and determine what needs to be changed and learn how to change. Then teachers and students have discussions focusing on critical self-regulation components: self-efficacy beliefs, goal setting and strategic planning, selecting the proper language learning strategies, strategy implementation, monitoring and evaluating, benefits associated with time and study environment management, and positive attribution for learning outcomes. Research evidence (Brown \& VanLehn, 1982; Weinert \& Helmke, 1995) indicates that a teacher's social guidance in the process of developing selfregulated learning is critical. Teachers who explicitly describe, model, and illustrate potentially useful strategies, and verbalize their thought processes as they perform tasks can enhance students' self-regulatory development greatly (Graham \& Harris, 1989; Sawyer, Graham, \& Harris, 1992). It is also important for teachers to provide students ample opportunities to reinforce the strategies they have learned. Once students understand how to evaluate their 
strategy use and to transfer the use of these strategies to other contexts, they complete their personalization of strategies.

Few studies have used approaches in which multiple essential self-regulated learning variables are simultaneously trained in regular classroom over a long period of time (Boekaerts, Pintrich, \& Zeidner., 2000). The feature of the current study design allows for filling the gap by systematically examining and evaluating both motivational variables and learning strategies in the context of L2 learning. It is also a significant attempt to integrate language learning strategy research into mainstream educational psychology. The new perspective on self-regulation has offered language educators a far broader perspective than previous focuses on learning strategies. As students are trained in new learning strategies, they must develop the motivation to use them. Successful L2 learners are not simply individuals who know more knowledge on L2 than others. They also have more effective and efficient strategies for accessing and using their knowledge, can persist more at difficult or uninteresting academic tasks, and can monitor and adjust their behaviors when learning does not occur.

\section{Limitations of the Present Study}

In interpreting the results of the current study, a number of limitations need to be kept in mind. As discussed in the first chapter, one of the limitations of the studies in the literature lies in the challenges of capturing the complex, dynamic, and highly contextualized nature of selfregulation in learning. The data analyzed in the current study is based on the students' selfreports. Although the instruments used exhibit appropriate levels of reliability and validity, when using self-report measures, researchers have difficulty in identifying how truthfully respondents answer. Social desirability might affect the way participants answer the items. However, all necessary efforts to ensure respondents that surveys were confidential were made in the current 
study. A mixed research method may be able to offer a better understanding of self-regulation. For example, with the purpose of triangulation, quantitative research methods and qualitative research methods can be used to seek convergence and corroboration of results when studying self-regulated learning in the context of L2 learning. In fact, besides questionnaire instruments, the participants' self-regulation diaries were also collected in the current study. The diary was mainly used to enhance the effect of self-regulated learning training. As expected, the process of answering questions in a learning diary regularly at home stimulated students' metacognitive thoughts. It also enhanced the transfer of the training contents presented in classrooms to the actual learning situation at home. In future study, the learning diary data could be analyzed to track the change of self-regulated learning variables over time during the training period.

In order to minimize differences in selectivity between different culture groups, the present study sample was chosen. Culture plays an important role in the nature and development of selfregulation (McInerney, 2008; Zhu, Valcke \& Schellens, 2008), as learners often behave in certain culturally approved and socially acceptable ways as they learn (Bedell \& Oxford, 1996). However, little research has explored cultural influences on self-regulated learning with strong methodologies (McInerney, 2011). Further empirical research that systematically examines how far elements of self-regulation differ by cultural groups is recommended. The present study demonstrates a linkage between self-regulation intervention and increased L2 proficiency and explores how to develop students' self-regulatory skills in the L2 classroom. Additional research is needed to discover where, when, and how students are most likely to apply their newly developed self-regulatory skills to situations outside of school. 


\section{References}

Alexander, P. A., Graham, S., \& Harris, K. R. (1998). A perspective on strategy research: Progress and prospects. Educational Psychology Review, 10(2), 129-154.

Anderson, C. A., \& Jennings, D. L. (1980). When experiences of failure promote expectations of success: The impact of attributing failure to ineffective strategies. Journal of Personality, 48, 393-405.

Anderson, N. J. (2002). The role of metacognition in second language teaching and learning. ERIC Digest, 4. Washington, DC: Center for Applied Linguistics.

Anderson, N. J. (2005). L2 learning strategies. In E. Hinkel (Ed.), Handbook of research in second language teaching and learning (pp. 757-772). Mahwah, NJ: Lawrence Erlbaum Associates.

Ames, C., \& Archer, J. (1988). Achievement goals in the classroom: Students' learning strategies and motivation processes. Journal of Educational Psychology, 80, 260- 267.

Ardasheva, Y., \& Tretter, T. R. (2013). Strategy Inventory for Language Learning-ELL Student Form: Testing for factorial validity. Modern Language Journal, 97(2), 472-487.

Bandura, A. (1976). Social learning theory. New York: Prentice Hall.

Bandura, A. (1977). Self-efficacy: Toward a unifying theory of behavioral change. Psychological Review, 84, 191-215.

Bandura, A. (1986). Social foundations of thought and action: A social cognitive theory. Englewood Cliffs, N.J.: Prentice Hall.

Bandura, A. (1997). Self-efficacy: The exercise of control. New York: Freeman.

Bedell, D.A., \& Oxford, R.L. (1996). Cross-cultural comparisons of language learning strategies in the People's Republic of China and other countries. In R. L. Oxford (Ed.), Language learning strategies around the world: Cross-cultural perspectives (pp. 47-60). Honolulu, HI: University of Hawaii Press.

Bentler, P.M. (1990), Comparative fit indexes in structural models, Psychological Bulletin, 107 (2), 238-46.

Bentler, P.M. (1992), On the fit of models to covariances and methodology to the Bulletin. Psychological Bulletin, 112 (3), 400.

Bialystok, E. (1981). The role of conscious strategies in second language proficiency. Canadian Modern Language Review 35, 372-94.

Boekaerts, M., Pintrich, P. R., \& Zeidner, M. (Eds.) (2000). Handbook of self-regulation. San Diego, CA: Academic.

Bong, M. (2001). Between- and within-domain relations of academic motivation among middle and high school students: self-efficacy, task-value, and achievement goals, Journal of Educational Psychology, 93(1), 23-34.

Bouffard-Bouchard, T. (1990). Influence of self-efficacy on performance in a cognitive task. Journal of Social Psychology, 130, 353-363. 
Britton, B. K., \& Tesser, A. (1991). Effects of time management practices of college grades. Journal of Educational Psychology, 83, 405-410.

Brown, J.S., \& VanLehn, K. (1982). Towards a generative theory of "bugs." In T.P. Carpenter, J. Moser, \& T. Romberg (Eds.) Addition and subtraction: A cognitive perspective (pp. 117135). Hillsdale, NJ: Lawrence Erlbaum. Journal of Biological Education. 13,119-122.

Browne, M. W., \& Cudeck, R. (1993). Alternative ways of assessing model fit. In: K. A. Bollen, \& J. S. Long (Eds.), Testing structural equation models (pp. 136-162). Beverly Hills, CA: Sage.

Chamot, A. U. (1987). The learning strategies of ESL students. In A. Wenden, \& J. Rubin (Eds.). Learner strategies in language learning (pp.71-84). Cambridge: Prentice-Hall.

Chamot, A.U. (2004). Issues in language learning strategy research and teaching. Electronic Journal of Foreign Language Teaching, 1(1), 14-26.

Chamot, A. U. (2005). The Cognitive Academic Language Learning Approach (CALLA): An update. In P. A. Richard-Amato, \& M. A. Snow (Eds.), Academic success for English language learners: Strategies for K-12 mainstream teachers (pp. 87-101). White Plains, NY: Longman.

Chamot, A. U., Barnhardt, S., El-Dinary, P. B., \& Robbins, J. (Eds.). (1999). The learning strategies handbook. New York: Longman.

Chamot, A. U., \& O’Malley, J. (1994). The CALLA handbook: Implementing the Cognitive Academic Language Learning Approach. Reading, MA: Addison- Wesley.

Chamot, A.U., \& Rubin, J. (1994). Comments on Janie Rees-Miller's 'A critical appraisal of learner training: theoretical bases and teaching implications' : Two readers react. TESOL Quarterly, 28(4), 771-76.

Chan, L. K. S., \& Moore, P. J. (2006). Development of attributional beliefs and strategic knowledge in Years 5-9: A longitudinal analysis. Educational Psychology, 26(2), 161185.

Chase, M. A. (2001). Children's self-efficacy, motivational intentions, and attributions in physical education and sport. Research Quarterly for Exercise and Sport, 72, 47-54.

Chen, C. S. (2002). Self-regulated learning strategies and achievement in an introduction to information systems course. Information Technology, Learning, and Performance Journal, 20(1), 11-25.

Cheng, L. (2008). The key to success: English language testing in China. Language Testing, 25 (1), 15-37.

Cleary, T. J., Callan, G., \& Zimmerman, B. J. (2012). Assessing self-regulation as a cyclical, context-specific phenomenon: Overview and analysis of SRL microanalytic protocols. Education Research International, 2012.

Cleary, T. J., \& Zimmerman, B. (2004) Self-regulation empowerment programme: A schoolbased program to enhance self-regulated and self-motivated cycles of student learning. Psychology in the Schools, 41(5), 537-50. 
Clifford, M. (1986). Comparative effects of strategy and effort attributions. British Journal of Educational Psychology, 56, 75-83.

Cohen, A. D. (1990). Language learning: Insights for learners, teachers, and researchers. New York: Newbury House.

Cohen, A. D. (1998). Strategies in learning and using a second language. New York: Longman.

Cohen, A. D., \& Macaro, E (2007). Learner Strategies. Oxford: Oxford University Press.

Cohen, A. D., \& Weaver, S. J. (2005). Styles and strategies-based instruction: A teachers' guide. Minneapolis, MN: Center for Advanced Research on Language Acquisition, University of Minnesota.

Cohen, A. D., Weaver, S. J., \& Li, T-Y. (1996). The impact of strategies-based instruction on speaking a foreign language. (CARLA Working Paper Series No. 4.) Minneapolis: Center for Advanced Research on Language Acquisition, University of Minnesota.

Crowley, S., \& Fan, X. (1997). Structural Equation Modeling: Basic Concepts and Applications in Personality Assessment Research. Journal of Personality Assessment, 68, 508-531.

Dickinson, L. (1987). Self-Instruction in language learning. Cambridge. Cambridge University Press.

Dörnyei, Z. (2005). The psychology of the language learner: Individual differences in second language acquisition. Mahwah, NJ: Lawrence Erlbaum.

Duncan, T. G., \& McKeachie, W. J. (2005). The making of the motivated strategies for learning questionnaire. Educational Psychologist, 40, 117-128.

Dweck, C. S. (1986). Motivational processes affecting learning. American Psychologist, 41, $1040-1048$.

Ehrman, M. (1990).The role of personality type in adult language learning: An ongoing investigation. In T. Parry, \& C. Stansfield (Eds.), Language aptitude reconsidered (pp. 126-178) Englewood Cliffs, NJ: Prentice Hall.

Ehrman, M., \& Oxford, R. L. (1990). Adult language learning styles and strategies in an intensive training setting. Modern Language Journal, 73, 311-327.

Eisenberg, N. (2010). Self-regulation and school readiness. Early Education and Development, 21(5), 681-698.

Elliott, E. S., \& Dweck, C. S. (1988). Goals: An approach to motivation and achievement. Journal of Personality and Social Psychology, 54, 5-12.

Ellis, R. (1994). The study of second language acquisition, Oxford: Oxford University Press.

Feng, C. H. (2010). A correlational study of language learning motivation and strategies of Chinese undergraduate, Canadian Social Science, 6(4), 202-209.

Flavell, J. H. (1979). Metacognition and cognitive monitoring: A new area of cognitivedevelopmental inquiry. American Psychologist, 34(10), 906-911.

Garcia, T., \& Pintrich, P. R. (1994). Regulating motivation and cognition in the classroom: The role of self-schemas and self-regulatory strategies. In D. H. Schunk, \& B. J. Zimmerman, 
Self-regulation of learning and performance: Issues and educational applications (pp. 127-153). Hillsdale, NJ: Lawrence Erlbaum Associates.

Glaser, C., \& Brunstein, J. C. (2007). Improving fourth-grade students' composition skills: effects of strategy instruction and self-regulation procedures. Journal of Educational Psychology, 99 (2), 297-310.

Graham, S. J., \& Harris K. R. (1989). A components analysis of cognitive strategy instruction: Effects on learning disabled students' compositions and self-efficacy. Journal of Educational Psychology, 81, 353-361.

Graham, S. J., \& Harris, K. R. (2000). The role of self-regulation and transcription skills in writing and writing development. Educational Psychologist, 35(1), 3-12.

Graham, S. J., \& Macaro, E. (2008). Strategy instruction in listening for lower-intermediate learners of French. Language Learning, 58 (4), 747-783.

Grant, H., \& Dweck, C. (2003). Clarifying achievement goals and their impact. Journal of Personality and Social Psychology, 85(3), 541-553.

Green, J. M., \& Oxford, R. L. (1995). A closer look at learning strategies, L2 proficiency, and gender. TESOL Quarterly, 29 (2), 261-297.

Gu, Y. (2007). Strategy-based instruction. In T. Yashima, \& T. Nabei (Eds.), Proceedings of the International Symposium on English Education in Japan: Exploring New Frontiers (pp. 21-38). Osaka: Yubunsha.

Guthrie, J.T., \& Wigfield, A. (2000) Engagement and motivation in reading. In M. Kamil and P. Mosenthal (Eds.). Handbook of reading research (pp. 403-422). Mahwah, NJ: Erlbaum.

Hsiao, T. Y., \& Oxford, R. L. (2002). Comparing theories of language learning strategies: a confirmatory factor analysis. The Modern Language Journal, 2, 368-383.

Hsieh, P. P., \& Schallert, D. L. (2008). Implications from self-efficacy and attribution theories or an understanding of undergraduates' motivation in a foreign language course. Contemporary Educational Psychology, 33(4), 513-532.

Houtveen, A. A. M., \& Grift, W. J. C. M. (2007). Effects of metacognitive strategy instruction and instruction time on reading comprehension. School Effectiveness and School Improvement, 18(2), 173-190.

Hu, L., \& Bentler, P. M. (1998). Fit indices in covariance structure modeling: Sensitivity to underparameterized model misspecification. Psychological Methods, 3, 424-453.

Huang. S. (2008). Assessing motivation and learning strategies using the motivated strategies for learning questionnaire in a foreign language learning context. Social Behavior and Personality, 36(4), 529-534.

Jagacinski, C. M., \& Nicholls, J. G. (1987). Competence and affect in task involvement and ego involvement: The impact of social comparison information. Journal of Educational Psychology, 79, 107- 114.

Jin, Y. (2005) The National College English Test of China. In Hamp- Lyons, L. (Chair), The big tests: Intentions and evidence. Symposium presented at International Association of Applied Linguistics (AILA) 2005 Conference in Madison, WI. 
Kramarski, B., \& Mevarech, Z. R. (2003). Enhancing mathematical reasoning in the classroom: Effects of cooperative learning and metacognitive training. American Educational Research Journal, 40, 281-310.

Kramarski, B., \& Michalsky, T. (2009). Investigating preservice teachers' professional growth in self-regulated environments. Journal of Educational Psychology, 101(1), 161-175.

Lee, H. W., Lim, K. Y., \& Grabowski, B. L. (2010). Improving self-regulation, learning strategy use, and achievement with metacognitive feedback. Educational Technology Research and Development, 58(6), 629-648.

MacIntyre, P. D. (1994). Variables underlying willingness to communicate: A causal analysis. Communication Research Reports, 11, 135-142.

Maehr, M. L., \& Zusho, A. (2009). Achievement goal theory: The past, present, and future. In K.R. Wentzel, \& A. Wigfield (Eds.), Handbook of motivation at school (pp. 77-104). New York: Routledge/Taylor \& Francis Group.

Martinez, M. E. (2006). What is metacognition? Phi Delta Kappan, 696-699.

Matuga, J. M. (2009). Self-Regulation, goal orientation, and academic achievement of secondary students in online university courses. Educational Technology and Society, 12(3), 4-11.

McDonough, S. H. (1995). Strategy and skill in learning a foreign language. London: Edward Arnold.

McDonough, S. K. (2001). Promoting self-regulation in foreign language learners. The Clearing House, 74(6), 323-326.

McInerney. D. M. (2008). The motivational roles of cultural differences and cultural identity in self-regulated learning. In D. Schunk and B. J. Zimmerman (Eds.), Motivation and selfregulated learning: Theory, research, and applications (pp. 368-400). New York: Erlbaum.

McInerney, D. M. (2011). Culture and self-regulation in educational contexts: Assessing the relationship of cultural group to self-regulation. In B. Zimmerman, \& D. Schunk (Eds.), Handbook of self-regulated learning and performance. Educational psychology handbook series (pp. 442-464). New York: Routledge.

Mendelsohn, D. (1994). Learning to listen: A strategy-based approach for the second-language learner. San Diego, CA: Dominie.

Mendelsohn, D. (1998). Teaching Listening. Annual Review of Applied Linguistics, 18, 81-101.

Naiman, N., Frohlich, M., Stern, H. H., \& Todesco, A. (1976). The good language learner. Toronto: Ontario Institute for Studies in Education.

Neber, H., \& Heller, K. A. (2002). Evaluation of a summer-school program for highly gifted secondary-school students: the German Pupils Academy, European Journal of Psychological Assessment, 18(3), 214-228.

Nguyen, L., \& Gu, Y. (2013). Strategy-based instruction: A learner-focused approach to developing learner autonomy. Language Teaching Research, 17(1), 9-30. 
Nosal, M., \& Nosal, E. (2003). Three-parameter Weibull generator for replacing missing observations. Paper presented at the meeting of the International Conference on Statistics and Related Fields, Honolulu, HI.

O'Malley, J. M. (1987). The effects of training in the use of learning strategies on learning English as a second language. In A. Wenden, \& J. Rubin (Eds.). Learner strategies in language learning (pp. 133-43). Cambridge: Prentice-Hall.

O'Malley, J. M., \& Chamot, A. U. (1990). Learning strategies in second language acquisition. Cambridge: Cambridge University Press.

O’Malley, J. M., Chamot, A. U., Stewner -Manzanares, G., Kupper, L., \& Russo, R. P. (1985). Learning strategies used by beginning and intermediate ESL students. Language Learning, 35, 21-46.

Oxford, R. L. (1989). Use of language learning strategies: a synthesis of studies with implications for strategy training. System, 17(2), 235-247.

Oxford, R.L. (1990). Language learning strategies: What every teacher should know. Englewood Cliffs, NJ: Newbury House.

Oxford, R.L. (1999). Anxiety and the language learner: new insights. In J.Arnold (Ed.). Affect in language learning. Cambridge: Cambridge University Press. 58-67.

Oxford, R. L. (2011). Teaching and researching language learning strategies. Longman.

Oxford, R. L., \& Burry-Stock, J. A. (1995). Assessing the use of language learning strategies worldwide with the ESL/EFL version of the strategy inventory for language learning (SILL). System, 23(1). 1-23.

Oxford, R.L., \& Ehrman, E. (1993). Second language research on individual differences. Annual Review of Applied Linguistics, 13, 188-205.

Oxford, R. L., \& Nyikos, M. (1989). Variables affecting choice of language learning strategies by university students. The Modern Language Journal, 73(3), 291-300.

Pajares, F. (1996). Self-efficacy beliefs in academic settings. Review of Educational Research, $66,543-578$.

Pajares, F. (2008). Motivational role of self-efficacy beliefs in self-regulated learning. In D. H. Schunk, \& B. J. Zimmerman (Eds.), Motivation and self-regulated learning: Theory, research and applications (pp. 111-139). New York: Erlbaum.

Perels, F., Dignath, C., \& Schmitz, B. (2009). Is it possible to improve mathematical achievement by means of self-regulation strategies? Evaluation of an intervention in regular math classes. European Journal of Psychology of Education, 24, 17-31.

Perry, N.E., \& Vandekamp, K.J.O. (2000). Creating classroom contexts that support young children's development of self-regulated learning. International Journal of Educational Research, 33, 821-43.

Pintrich, P. R. (2000). An achievement goal theory perspective on issues in motivation terminology, theory, and research. Contemporary Educational Psychology, 25, 92-104. 
Pintrich, P. R., \& De Groot, E. V. (1990). Motivational and self-regulated learning components of classroom academic performance. Journal of Educational Psychology, 82, 33- 40.

Pintrich, P. R., \& Schunk, D. H. (1996). Motivation in education: theory, research and applications. Englewood Cliffs: NJ: Prentice-Hall.

Pintrich, P. R., \& Schunk, D. H. (2002). Motivation in education: theory, research, and applications, 2nd ed. Englewood Cliffs (NJ: Prentice-Hall, Inc).

Pintrich, P. R., Smith, D., Garcia, T., \& Mc Keachie, W. (1991). The motivated strategies for learning questionnaire (MSLQ). Ann Arbor: University of Michigan.

Pintrich, P. R, Smith, D., Garcia, T., \& McKeachie, W. (1993). Reliability and predictive validity of the motivated strategies for learning questionnaire (MSLQ). Educational and Psychological Measurement, 53, 801-813.

Pintrich, P. R., \& Zusho, A. (2002). The development of academic self-regulation: The role of cognitive and motivational factors. In A. Wigfield and J. Eccles (Eds.), Development of achievement motivation (pp. 249-284). San Diego, CA: Academic Press.

Pintrich, P. R., \& Zusho, A. (2007). Student motivation and self-regulated learning in the college classroom. In R. Perry, \& J. Smart (Eds.), The scholarship of teaching and learning in higher education: An evidence-based perspective (pp. 731-813). New York: Springer.

Plonsky, L. (2011), The effectiveness of second language strategy instruction: A meta-analysis. Language Learning, 61. 993-1038.

Politzer, R. (1983). An exploratory study of self-reported language learning behaviors and their relation to achievement. Studies in Second Language Acquisition, 6, 54-68.

Randi, J., \& Corno, L. (2000). Teacher innovations in self-regulated learning. In P. R. Pintrich, M. Boekaerts, \& M. Zeidner (Eds.), Handbook of self-regulation (pp. 651-685). Orlando, FL: Academic Press.

Rotter, J. B. (1954). Social learning and clinical psychology. New York: Prentice Hall.

Rubin, J. (1981). The study of cognitive processes in second language learning. Applied Linguistics, 1, 117-131.

Rubin, J. (2001). Language learner self-management. Journal of Asian Pacific Communication, 11(1), 25-37.

Sawyer, R., Graham, S., \& Harris, K.R. (1992). Direct teaching, strategy instruction, and strategy instruction with explicit self-regulation: Effects on learning disabled students' compositions and self-efficacy. Journal of Education Psychology, 84, 340-352.

Schmidt, R., Boraie, D., \& Kassabgy, O. (1996). Foreign language motivation: Internal structure and external connections. In R. Oxford (Ed.), Language learning motivation: Pathways to the new century (pp. 9-70). Honolulu: University of Hawaii, Second Language Teaching and Curriculum Center.

Schmidt, R. \& Watanabe, Y. (2001). Motivation, learning strategies and pedagogical preferences in foreign language learning. In Z. Dörnyei, \& R. Schmidt (eds.), Motivation and second language acquisition (pp. 313-359). Honolulu: University of Hawaii Second Language Teaching and Curriculum Center. 
Schmitz, B. (2001). Self-monitoring zur Unterstützung des Transfers einer Schulung in Selbstregulation für Studierende. Eine prozessanalytische Studie [Self-monitoring for supporting the transfer of a training in self-regulation for undergraduates. Processanalytical study]. Zeitschrift für Pädagogische Psychologie. 15, 179-195.

Schmitz, B., \& Wiese, B. S. (2006). New perspectives for the evaluation of training sessions in self-regulated learning: Time-series analyses of diary data. Contemporary Educational Psychology, 31, 64-96.

Schraw, G., Crippen, K. J., \& Hartley, K. (2006). Promoting self-regulation in science education: Metacognition as part of a broader perspective on learning. Research in Science Education, 36, 111-139.

Schraw, G., \& Moshman, D. (1995). Metacognitive theories. Educational Psychology Review, 7(4), 351-371.

Schunk, D. H. (1989). Self-efficacy and cognitive skill learning. In C. Ames, \& R. Ames (Eds.), Research on Motivation in Education (Vol. 3, pp. 13-44). San Diego. CA: Academic Press.

Schunk, D. H. (1995). Self-efficacy and education and instruction. In E. Maddux (Eds.), Selfefficacy, adaptation, and adjustment: Theory, research, and application (pp. 281-304). New York: Plenum Press.

Schunk, D. H. (1996). Self-efficacy for learning and performance. Paper presented at the annual meeting of the American Educational Research Association, New York.

Schunk, D. H. (2005). Self-regulated learning: The educational legacy of Paul R. Pintrich. Educational Psychologist, 40(2), 85-94.

Schunk, D. H. (2008). Metacognition, self-regulation, and self-regulated learning: Research recommendations. Educational Psychology Review, 20(4), 463-467.

Schunk, D. H. (2013). Self-regulated learning: Where we are and where we might go. Paper presented at the annual meeting of the American Educational Research Association, San Francisco,

Schunk, D. H., \& Ertmer, P. A. (2000). Self-regulation and academic learning: self-efficacy enhancing interventions. In M. Boekaerts, P. R. Pintrich, \& M. Zeidner (Eds.), Handbook of self-regulation (pp. 631-649). San Diego: Academic Press.

Schunk, D. H., \& Swartz, C. W. (1993). Goals and progress feedback: Effects on self-efficacy and writing achievement. Contemporary Educational Psychology, 18, 337-354.

Schunk, D. H., \& Zimmerman, B. J. (1998). Self-regulated learning: From teaching to selfreflective practice. New York: Guilford Press.

Skehan, P. (1989). Individual differences in second language learning. Great Britain: Chapman and Hall, Inc

Souvignier, E., \& Mokhlesgerami, J. (2006). Using self-regulation as a framework for implementing strategy-instruction to foster reading comprehension. Learning and Instruction, 16, 57-71. 
Sperling, R. A., Howard, B. C., \& Staley, R. (2004). Metacognition and self-regulated learning constructs. Educational Research and Evaluation, 10, 117-139

Stoeger, H., \& Ziegler, A. (2008). Evaluation of a classroom based training to improve selfregulation in time management tasks during homework activities with fourth graders. Metacognition and Learning, 3(3), 207-230.

Stoffa, R., Kush, J. C., \& Heo. M. (2011). Using motivated strategies for learning questionnaire and strategy inventory for language learning in assessing motivation and learning strategies of generation 1.5 Korean immigrant students. Education Research International Retrieved January $2^{\text {nd }} 2011$ from www. Hindawi.com/ journals/ edu/ 2011/ 491276/html.

Thompson, I., \& Rubin, J. (1996). Can strategy instruction improve listening comprehension? Foreign Language Annals, 29, 3, 331-342.

Victori, M., \& Lockhart, W. (1995). Enhancing metacognition in self-directed language learning. System, 23(2), 223-234.

Weiner, B. (1979). A theory of motivation for some classroom experiences. Journal of Educational Psychology, 71, 3-25.

Weiner, B. (1992). Human Motivation: Metaphors, Theories, and Research. Sage Publications.

Weiner, B., Russell, D., \& Lerman, D. (1979). The cognition-emotion process in achievementrelated contexts. Journal of Personality and Social Psychology, 37, 1211-1220.

Weinert, F. E., \& Helmke, A. (1995). Learning form wise mother nature or big brother instructor: the wrong choice as seen from an educational perspective. Educational Psychologist, 30, $135-142$.

Weinstein, C. E., Husman, J., \& Dierking, D. R. (2000). Self-Regulation intervention with a focus on learning strategies. In M. Boekaerts, P. R. Pintrich, \& M. Zeidner (Eds.), Handbook of self-regulation (pp. 727-747). San Diego, CA: Academic Press.

Weinstein, C. E., Schulte, A. C., \& Palmer, D. R. (1987). LASSI: Learning and Study Strategies Inventory. Clearwater, FL: H. \& H.

Wenden, A. (1982). The process of self-directed learning: A study of adult language learners. Unpublished doctoral dissertation. New York: Teachers College, Columbia University.

Wharton, G. (2000). Language learning strategy use of bilingual foreign language learners in Singapore. Language Learning, 50(2), 203-244.

Whitebread, D., Coltman, P., Pasternak, D. P., Sangster, C., Grau, V., Bingham, S., Almeqdad, Q., \& Demetriou, D. (2009). The development of two observational tools for assessing metacognition and self-regulated learning in young children. Metacognition and Learning, $4(1), 63-85$.

Wigfield, A., Guthrie, J., Perencevich, K., Taboada, A., Klauda, S., McRae, A., \& Barbosa, P. (2008). Role of reading engagement in mediating effects of reading comprehension instruction on reading outcomes. Psychology in the Schools, 45, 432-445.

Wild, K. P., \& Schiefele, U. (1994). Lernstrategien im Studium: Ergebnisse zur Faktorenstruktur und Reliabilität eines neuen Fragebogens. [Learning Strategies in Academic Studies: 
Results of the factor structure and reliability of a newly developed questionnaire]. Zeitschrift für Differentielle und Diagnostische Psychologie [Journal of Differential and Diagnostic Psychology], 15, 185-200.

Winter, F. I., Greene, J. A., \& Costich, C. M. (2008). Self-regulation of learning within computer-based learning environments: A critical analysis. Educational Psychology Review, 20, 429-444.

Wu, J., \& Cheng, B. (1992) Jilide xuexicelue liangbiaozhi xiuding (A Chinese version of the Motivated Strategies for Learning Questionnaire). Ceyan Niankan, 39, 59-78.

Yang, H., \& Weir, C. (2001) Validation study of the National College English Test, third edition. Shanghai, China: Shanghai Foreign Language Education Press.

Yang, N. D. (1992). Second language learners' beliefs about language learning and their use of learning strategies: A study of college studetns of English in Taiwan. Unpublished doctoral dissertation. University of Texas, Austin, TX.

Zhang, L. J. (2008). Constructivist pedagogy in strategic reading instruction: Exploring pathways to learner development in the English as a second language (ESL) classroom. Instructional Science, 36(2), 89-116.

Zhu, C., Valcke, M., \& Schellens, T. (2008). A cross- cultural study of Chinese and Flemish university students, Asia Pacific Education Review, 6, 163-169.

Zimmerman, B. J. (1989). Models of self-regulated learning and academic achievement. In B. J. Zimmerman, \& D. H. Schunk (Eds.) Self-regulated learning and academic achievement: Theory, research, and practice (pp. 1-25). New York: Springer.

Zimmerman, B. J. (1994). Dimensions of academic self-regulation: A conceptual framework for education. In D. H. Schunk \& B. J. Zimmerman (Eds.), Self-regulation of learning and performance: Issues and educational applications (pp. 3-21). Hillsdale, NJ: Lawrence Erlbaum Associates, Inc.

Zimmerman, B. J. (2000). Attaining self-regulation: A social cognitive perspective. In M. Boekaerts, P. Pintrich and M. Zeidner (Eds.), Handbook of self-regulation (pp. 13-39). Burlington, MA: Elsevier Academic Press.

Zimmerman, B. J. (2004). Socialcultural influence and students' development of academic selfregulation: A social-cognitive perspective. In D. M. McInerney, \& S. Van Etten (Eds.), Big theories revisited. Research on socialcultural influences on motivation and learning (pp. 139-164). Greenwich, CT: Information Age.

Zimmerman, B. J. (2008). Investigating self-regulation and motivation: Historical background, methodological developments, and future prospects. American Educational Research Journal, 45(1), 166-83.

Zimmerman, B. J., Bandura, A., \& Martinez-Pons, M. (1992). Self-motivation for academic attainment: The role of self-efficacy beliefs and personal goal setting. American Educational Research Journal, 29, 663-676.

Zimmerman, B.J., Bonner, S., \& Kovach, R. (1996). Developing self-regulated learners: Beyond achievement to self-efficacy. Washington, DC: American Psychological Association. 
Zimmerman, B.J., \& Cleary, T. J. (2009). Motives to self-regulate learning: A social-cognitive account. In K. Wentzel and A. Wigfield (Eds.), Handbook on motivation at school (pp. 247-264). Boca Raton, FL: Lawrence Erlbaum Associates/Taylor \&Francis.

Zimmerman, B. J., \& Kitsantas, A. (1997). Developmental phases in self-regulation: Shifting from process goals to outcome goals. Journal of Educational Psychology, 89(1), 29-36.

Zimmerman, B. J., \& Kitsantas, A. (1999). Acquiring writing revision skill: Shifting from process to outcome self-regulatory goals. Journal of Educational Psychology, 91, 1-10.

Zimmerman, B.J., \& Martinez-Pons, M. (1988). Construct validation of a strategy model of student self-regulated learning. Journal of Educational Psychology, 80, 284-290. 


\section{Appendices}

\section{Appendix A}

\section{MSLQ Item List}

The following is a list of items that make up the MSLQ (Pintrich, Smith, Garcia \& McKeachie, 1991).

\section{Motivated Strategies for Learning Questionnaire}

The following questions ask about your motivation for and attitudes about this class.

Remember there is no right or wrong answer, just answer as accurately as possible. Use the scale below to answer the questions. If you think the statement is very true of you, circle 7; if a statement is not at all true of you, circle 1. If the statement is more or less true of you, find the number between 1 and 7 that best describes you.
12
3
4
5
6
Not at all Very true
Very true of me

1. In a class like this, I prefer course material that really challenges me so I can learn new things.

2. If I study in appropriate ways, then I will be able to learn the material in this course.

3. When I take a test I think about how poorly I am doing compared with other students.

4. I think I will be able to use what I learn in this course in other courses.

5. I believe I will receive an excellent grade in this class.

6. I'm certain I can understand the most difficult material presented in the readings for this course.

7. Getting a good grade in this class is the most satisfying thing for me right now.

8. When I take a test I think about items on other parts of the test I can't answer.

9. It is my own fault if I don't learn the material in this course.

10. It is important for me to learn the course material in this class.

11. The most important thing for me right now is improving my overall grade point average, so

my main concern in this class is getting a good grade.

12. I'm confident I can learn the basic concepts taught in this course.

13. If I can, I want to get better grades in this class than most of the other students.

14. When I take tests I think of the consequences of failing.

15. I'm confident I can understand the most complex material presented by the instructor in this course.

16. In a class like this, I prefer course material that arouses my curiosity, even if it is difficult to learn.

17. I am very interested in the content area of this course.

18. If I try hard enough, then I will understand the course material.

19. I have an uneasy, upset feeling when I take an exam.

20. I'm confident I can do an excellent job on the assignments and tests in this course.

21. I expect to do well in this class.

22. The most satisfying thing for me in this course is trying to understand the content as thoroughly as possible.

23. I think the course material in this class is useful for me to learn.

24. When I have the opportunity in this class, I choose course assignments that I can learn from even if they don't guarantee a good grade.

25. If I don't understand the course material, it is because I didn't try hard enough. 
26. I like the subject matter of this course.

27. Understanding the subject matter of this course is very important to me.

28. I feel my heart beating fast when I take an exam.

29. I'm certain I can master the skills being taught in this class.

30. I want to do well in this class because it is important to show my ability to my family, friends, employer, or others.

31. Considering the difficulty of this course, the teacher, and my skills, I think I will do well in this class. 


\section{Appendix B}

学习动机量表

这份学习动机量表的目的是在于了解你学习英语的动机和态度。这些陈述并没有对或错的标准答案。 依据每一项陈述对于你的真实性, 在量表中 $(1 ， 2 ， 3 ， 4 ， 5 ， 6 ， 7)$ 标出你的答案。如果你认为该陈述 完全符合你的情况, 请选择 7 , 如果该陈述完全部不合你的情况, 请选择 1 。如果该陈述介乎符合和不符 合之间, 请选择 1 至 7 之间适当的数字代表你的真实情况。

$\begin{array}{llllllll}1 & 2 & 3 & 4 & 6 & 6 & 7\end{array}$

完全不符合

完全符合

\begin{tabular}{|c|c|c|c|c|c|c|c|c|}
\hline 1. & 在这门课中, 我比较喜欢有挑战的内容, 以便能学到 & 1 & 2 & 3 & 4 & 5 & 6 & \\
\hline 2. & 如果我用对方法读书, 我就可以学会这门课的内容。 & 1 & 2 & 3 & 4 & 5 & 6 & 7 \\
\hline 3. & 在考试时, 我会想到: 和其他同学相比我是多么的差劲。 & 1 & 2 & 3 & 4 & 5 & 6 & 7 \\
\hline 4. & 我认为我可以把在这门课学所学到的应用到别的课程中。 & 1 & 2 & 3 & 4 & 5 & 6 & 7 \\
\hline 5. & 在这门课中, 我相信我会得到优异成绩。 & 1 & 2 & 3 & 4 & 5 & 6 & 7 \\
\hline 6. & 我确定我可以了解这门课的课文中最困难的部分。 & 1 & 2 & 3 & 4 & 5 & 6 & 7 \\
\hline 7. & 在这门课得到好成绩, 是我最满意的事。 & 1 & 2 & 3 & 4 & 5 & 6 & 7 \\
\hline 8. & 在考试当时, 我会一边作答一边想到我不会的题目。 & 1 & 2 & 3 & 4 & 5 & 6 & 7 \\
\hline 9. & 如果我没学会这门课的内容, 那是我自己的过错。 & 1 & 2 & 3 & 4 & 5 & 6 & 7 \\
\hline 10. & 学会这门课的内容对我是重要的。 & 1 & 2 & 3 & 4 & 5 & 6 & 7 \\
\hline 11. & $\begin{array}{l}\text { 目前最重要的的事就是提高我的学期总成绩; 所以, 在这门课我 } \\
\text { 最开心的事就是得到好成绩。 }\end{array}$ & 1 & 2 & 3 & 4 & 5 & 6 & \\
\hline 12. & 我有信心我可以学会这门课所教的基本观念。 & 1 & 2 & 3 & 4 & 5 & 6 & 7 \\
\hline 13. & 如果可以的话, 我要我的成绩比班上大多数同学好。 & 1 & 2 & 3 & 4 & 5 & 6 & 7 \\
\hline 14. & 在考试当时, 我会想到考不好的后果。 & 1 & 2 & 3 & \pm & 5 & 6 & 7 \\
\hline 15. & 我有信心我能了解老师在这门课里所教的最复杂的内容。 & 1 & 2 & 3 & \pm & U & 6 & 7 \\
\hline 16. & $\begin{array}{l}\text { 在这门课里, 我比较喜欢能引起我的好奇心的内容, 即使这些内 } \\
\text { 容难以学习。 }\end{array}$ & 1 & 2 & 3 & 4 & 5 & 6 & 7 \\
\hline 17. & 我对这门课的内容很有兴趣。 & 1 & 2 & 3 & 4 & 5 & 6 & 7 \\
\hline 18. & 如果我够用功的话, 那么我就会了解这门课的内容。 & 1 & 2 & 3 & 4 & 5 & 6 & 7 \\
\hline 19. & 在考试当时, 我会感觉不自在, 浑身不舒服。 & 1 & 2 & 3 & t & 5 & 6 & 7 \\
\hline 20. & 我有信心在这门课里的作业和考试表现优异。 & 1 & 2 & 3 & 4 & 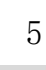 & 6 & 7 \\
\hline 21. & 我预期在这门课中表现良好。 & 1 & 2 & 3 & 4 & 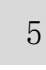 & 6 & 7 \\
\hline 22. & 在这门课里, 最令我满意的事就是尽量把课程内容彻底搞懂。 & 1 & 2 & 3 & 4 & 5 & 6 & 7 \\
\hline 23. & 我认为学习这门课的内容对我是有用处的。 & 1 & 2 & 3 & 4 & 5 & 6 & 7 \\
\hline 24. & 生这门课里, 如果有机会挑选作业, 我会挑选我能从中学到 & 1 & 2 & 3 & & & 6 & \\
\hline
\end{tabular}


的作业, 即使并不能保证好成绩。

25. 如果我不了解这门课的内容, 那是因为我不够用功。 $\quad \begin{array}{lllllll}1 & 2 & 3 & 4 & 5 & 6 & 7\end{array}$

26. 我喜欢这门课的内容。 $\quad \begin{array}{lllllll}1 & 2 & 3 & 4 & 5 & 6 & 7\end{array}$

27. 了解这门课的内容对我是重要的。 $\quad \begin{array}{lllllll}1 & 2 & 3 & 4 & 5 & 6 & 7\end{array}$

28. 在考试当时, 我觉得我心跳很快。 $\quad \begin{array}{lllllll}1 & 2 & 3 & 4 & 5 & 6 & 7\end{array}$

29. 我确定我能精通这门课所教的技能或技巧。 $\quad \begin{array}{lllllll} & 2 & 3 & 4 & 5 & 6 & 7\end{array}$

30. 我要在班上表现得好, 因为对我的家人、朋友、或其他人展示我 $\quad \begin{array}{llllllll}1 & 2 & 3 & 4 & 5 & 6 & 7\end{array}$ 的能力是重要的。

31. 考虑这门课的困难程度、老师、和我个人的技巧, 我想我会表现 $\quad \begin{array}{llllllll}1 & 2 & 3 & 4 & 5 & 6 & 7\end{array}$ 良好。 


\title{
Appendix C
}

\author{
SILL Item List
}

The following is a list of items that make up the SILL ELL Student Form (Ardasheva \& Tretter, 2013)

Strategy Inventory for Language Learning (SILL)-ELL Student Form

This form is for students of English as a second or foreign language. On the separate worksheet, write the response $(1,2,3,4$ or 5$)$ that tells HOW TRUE OF YOU THE STATEMENT IS.

1. Never or almost never true of me

2. Usually not true of me

3. Somewhat true of me

4. Usually true of me

5. Always or almost always true of me

Part A

1. I use flashcards to learn new English words.

2. I use rhymes to help me learn new English words.

3. I act out new English words.

4. I use new English words in a sentence to help me learn them.

5. I learn new words by thinking about when I can use them.

6. When I hear a new English word I think of a picture to help me learn the word.

7. I learn new words by thinking about where I first saw them on the page, on the board, or on a street sign.

Part B

8. I read for fun in English.

9. I first read a page (a text) quickly and then go back and read it carefully.

10. I look for words in English that are like my own language.

11. I break long words into small parts to figure out what they mean.

12. I make summaries of things I hear or read in English.

Part C

13. If I can't think of an English word, I show what I mean with my hands.

14. I make up a new word if I can't think of an English word.

15. When I read in English, I don't look up every new word in a dictionary.

16. I try to guess (predict) what people will say next in English.

17. If I can't think of an English word, I use a word that means the same thing.

Part D

18. I see my English mistakes and try to do better.

19. I listen well (carefully) when people speak English.

20. I look for ways to be a better student of English.

21. I think about how well I am doing in English.

Part E

22. I give myself a gift or a treat when I do well in English. 
23. I write about how I feel when I am learning English in my journal.

24. I talk to people about how I feel when I am learning English.

Part F

25. If I don't understand, I ask English speakers to slow down or say it again.

26. I ask English speakers to correct me when I talk.

27. I practice English with other students.

28. I ask for help from English speakers. 


\section{Appendix D}

语言学习策略量表

这份语言学习策略量表是为学英语的学生所设计。内容关于英语学习状况等陈述。请仔细阅读每项陈 述。依据每一项陈述对于你的真实性, 在量表中 $(1 ， 2 ， 3 ， 4 ， 5)$ 标出你的答案。

你的回答是根据该陈述有多么像你的程度。不要依照你认为自己应该是什么样子或是别人是怎么认为 的来回答。这些陈述并没有对或错的标准答案。在谨慎小心的情况下, 快速作答。这份问卷通常需花二 十到三十分钟。如果有问题，马上告知你的老师。

1. 「我从来都没有或是几乎没有」表示该陈述的正确性很低。

2. 「我通常没有」表示该陈述的正确性没有超过一半。

3. 「有点像我」表示该陈述的正确性为一半。

4. 「我通常是这样」表示该陈述的正确性已超过一半。

5. 「我一直都是这样，或是几乎一向如此」表示该陈述的正确性几乎百分之百。

\section{Part A}

1 学习新的单词时, 我会把新学的东西联想到已学过的部分。 $\begin{array}{lllll}1 & 2 & 3 & 4 & 5\end{array}$

*2 我会用新学的英语单词造句, 以加深记忆。

*3 我会把英语单词的发音与其相关的形象或图形联想, 帮助记忆。 $\begin{array}{lllll}1 & 2 & 3 & 4 & 5\end{array}$

*4 我会借着想象使用某个英语单词的可能状况，来记忆那个单词。

*5 我会运用相类似的发音来记忆英语生词。（如 rice 和 ice; no 和 know）

*6 我会使用单词卡来背英语生词。

$* 7$ 我会使用动作来记忆英语生词。

8 我会时常复习英语功课。

*9 我会利用英语单词或词组出现的位置来记忆。

10 我会反复练习说或写英语生词。

11 我会尝试说的像以英语为母语的人一样。

12 我会练习英语发音。

13 我会以不同的方式练习我所学的英语。

14 我会尝试以英语交谈。

15 我会看英语发音的电视节目或电影，或收听英语广播。

*16 我会阅读英语书刊以自娱。

17 我会用英语写笔记、书信、或报告。

$\begin{array}{lllll}1 & 2 & 3 & 4 & 5\end{array}$

$\begin{array}{lllll}1 & 2 & 3 & 4 & 5\end{array}$

*18 我会先快速汶览文章, 然后再回去仔细阅读。

*19 我会寻找英语与中文之间的相同与相异处。

20 我会尝试找出英语的句型。 $1 \begin{array}{lllll}1 & 2 & 3 & 4 & 5\end{array}$

*21 我会把一个英语生词分解成几个我认得的部分（如前缀或词根），以找出它 $1122 \quad 3 \quad 4 \quad 5$ 的意义。 


\begin{tabular}{|c|c|c|c|c|c|c|}
\hline$* 23$ & 我会总结我所听到的或读到的英语。 & 1 & 2 & 3 & 4 & 5 \\
\hline 24 & 我遇到不熟悉的英语单词时, 我会猜一猜它的意思。 & 1 & 2 & 3 & 4 & 5 \\
\hline$* 25$ & 在英语会话中, 如果我想不起来某个字, 我会使用手势或动作来表达。 & 1 & 2 & 3 & 4 & 5 \\
\hline$* 26$ & $\begin{array}{l}\text { 当我不知道合适的英语单词时, 我会自己造词来表达。（如用 air ball 来 } \\
\text { 表达 balloon） }\end{array}$ & 1 & 2 & 3 & 4 & 5 \\
\hline$* 27$ & 在阅读英语时, 我不会每个词都去查字典。 & 1 & 2 & 3 & 4 & 5 \\
\hline$* 28$ & 我会去猜测别人下一句要说的英语。 & 1 & 2 & 3 & 4 & 5 \\
\hline$* 29$ & 当我想不起来某个英语单词时, 我会使用意义相通的字词。 & 1 & 2 & 3 & 4 & 5 \\
\hline 30 & 我会找各种方式来运用我所学的英语。 & & & & & \\
\hline$* 31$ & 我会留意自己的英语错误, 并利用它来改进。 & 1 & 2 & 3 & 4 & 5 \\
\hline$* 32$ & 当别人说英语时, 我会特别留意。 & 1 & 2 & 3 & 4 & 5 \\
\hline$* 33$ & 我会试着找出任何学好英语的方法。 & 1 & 2 & 3 & 4 & 5 \\
\hline 34 & 我会订立作息表, 以使自己有足够的时间学习英语。 & 1 & 2 & 3 & 4 & 5 \\
\hline 35 & 我会留意寻访可以用英语交谈的对象。 & 1 & 2 & 3 & 4 & 5 \\
\hline 36 & 我会寻找时机多读英语。 & 1 & 2 & 3 & 4 & 5 \\
\hline 37 & 我有明确的目标, 改进我的英语技能。 & 1 & 2 & 3 & 4 & 5 \\
\hline$* 38$ & 我会考量自己学习英语的进展。 & 1 & 2 & 3 & 4 & 5 \\
\hline 39 & 每当我感到害怕使用英语时, 我会设法使自己心情放松。 & 1 & 2 & 3 & 4 & 5 \\
\hline 40 & 即使害怕犯错, 我仍会鼓励自己说英语。 & 1 & 2 & 3 & 4 & 5 \\
\hline$* 41$ & 每当我的英语表象良好, 我会鼓励自己。 & 1 & 2 & 3 & 4 & 5 \\
\hline 42 & 当我读英语或说英语的时候, 我会注意自己是否紧张。 & 1 & 2 & 3 & 4 & 5 \\
\hline$* 43$ & 我会用英语学习日志写下学英语的感受。 & 1 & 2 & 3 & 4 & 5 \\
\hline$* 44$ & 我会和别人讨论自己学英语的感受。 & 1 & 2 & 3 & 4 & 5 \\
\hline$* 45$ & $\begin{array}{l}\text { 假如在英语会话时, 我有听不懂的地方, 我会要求对方说慢一点或重说一 } \\
\text { 遍。 }\end{array}$ & 1 & 2 & 3 & 4 & 5 \\
\hline$* 46$ & 说英语时我会要求对方改正我的错误。 & 1 & 2 & 3 & 4 & 5 \\
\hline$* 47$ & 我会与其他同学练习英语。 & 1 & 2 & 3 & 4 & 5 \\
\hline$* 48$ & 我会向讲英语的人求助。 & 1 & 2 & 3 & 4 & 5 \\
\hline 49 & 我会发问以澄清及证实英语上的问题。 & 1 & 2 & 3 & 4 & 5 \\
\hline 50 & 我会试着学习英语国家的文化。 & 1 & 2 & 3 & 4 & 5 \\
\hline
\end{tabular}

Note. The items with * in the above questionnaire are Chinese version of 28 items in SILL ELL Student Form (Ardasheva \& Tretter, 2013) 


\section{Appendix E}

IRB Approval Letter

\section{a I I E R I TY O F WRKANSAS}

Office of Research Compliance Institutional Review Board

June 25, 2014

MEMORANDUM

TO:

$\mathrm{Lu} \mathrm{Yu}$

Felicia Lincoln

FROM:

Ro Windwalker

IRB Coordinator

RE:

New Protocol Approval

IRB Protocol \#:

$14-06-780$

Protocol Title:

Effects of Training on Self-Regulated Learning for Second Language Learners

Review Type:

$\triangle$ EXEMPT $\square$ EXPEDITED $\square$ FULL IRB

Approved Project Period: $\quad$ Start Date: 06/25/2014 Expiration Date: 06/24/2015

Your protocol has been approved by the IRB. Protocols are approved for a maximum period of one year. If you wish to continue the project past the approved project period (see above), you must submit a request, using the form Continuing Review for IRB Approved Projects, prior to the expiration date. This form is available from the IRB Coordinator or on the Research Compliance website (http://vpred.uark.edu/210.php). As a courtesy, you will be sent a reminder two months in advance of that date. However, failure to receive a reminder does not negate your obligation to make the request in sufficient time for review and approval. Federal regulations prohibit retroactive approval of continuation. Failure to receive approval to continue the project prior to the expiration date will result in Termination of the protocol approval. The IRB Coordinator can give you guidance on submission times.

This protocol has been approved for $\mathbf{3 0 0}$ participants. If you wish to make any modifications in the approved protocol, including enrolling more than this number, you must seek approval prior to implementing those changes. All modifications should be requested in writing (email is acceptable) and must provide sufficient detail to assess the impact of the change.

If you have questions or need any assistance from the IRB, please contact me at 210 Administration Building, 5-2208, or irb@uark.edu. 